Florida International University FIU Digital Commons

\title{
Earnings Management to Achieve the Peer Performance Benchmark
}

\author{
Sheng Yi \\ Florida International University, sheyi@fiu.edu
}

DOI: $10.25148 /$ etd.FIDC000706

Follow this and additional works at: https://digitalcommons.fiu.edu/etd

Part of the Accounting Commons

\section{Recommended Citation}

Yi, Sheng, "Earnings Management to Achieve the Peer Performance Benchmark" (2016). FIU Electronic Theses and Dissertations. 2619. https://digitalcommons.fiu.edu/etd/2619

This work is brought to you for free and open access by the University Graduate School at FIU Digital Commons. It has been accepted for inclusion in FIU Electronic Theses and Dissertations by an authorized administrator of FIU Digital Commons. For more information, please contact dcc@fiu.edu. 


\title{
FLORIDA INTERNATIONAL UNIVERSITY
}

Miami, Florida

\section{EARNINGS MANAGEMENT TO ACHIEVE THE PEER PERFORMANCE BENCHMARK}

A dissertation submitted in partial fulfillment of

\author{
the requirements for the degree of \\ DOCTOR OF PHILOSOPHY \\ in \\ BUSINESS ADMINISTRATION
}

by

Sheng Yi

2016 
To: Acting Dean Jose M. Aldrich

College of Business

This dissertation, written by Sheng Yi, and entitled Earnings Management to Achieve Peer Performance Benchmark, having been approved in respect to style and intellectual content, is referred to you for judgment.

We have read this dissertation and recommend that it be approved.

Clark M. Wheatley

Jung Hoon Kim

Jonathan Milian

Qiang Kang

Abhijit Barua, Major Professor

Date of Defense: June 16, 2016

The dissertation of Sheng Yi is approved.

Acting Dean Jose M. Aldrich

College of Business

Andrés G. Gil

Vice President for Research and Economic Development and Dean of the University Graduate School

Florida International University, 2016 
(C) Copyright 2016 by Sheng Yi

All rights reserved. 


\section{DEDICATION}

This paper is for you, my father, Yi Xian Yun and my mother, Zhu Yun Yu. I love both of you very much. 


\section{ACKNOWLEDGMENTS}

I would like to express my sincere appreciation to my major professor: Dr. Abhijit Barua for his support throughout my Ph.D. study at Florida International University. Without his tireless guidance, supervision and inspiration, the timely goals of my dissertation would not have been achieved.

I would like to thank my committee members Dr. Qiang Kang, Dr. Jung Hoon Kim, Dr. Jonathan Milian, Dr. Clark Wheatley and Dr. Abhijit Barua for their precious time and valuable comments.

I would like to thank Dr. Ruth Ann McEwen, Director, School of Accounting, FIU, for her trust and support. 


\section{ABSTRACT OF THE DISSERTATION \\ EARNINGS MANAGEMENT TO ACHIEVE THE PEER PERFORMANCE \\ BENCHMARK}

by

Sheng Yi

Florida International University, 2016

Miami, Florida

Professor Abhijit Barua, Major Professor

Other than three extensively researched earnings thresholds, avoiding earnings declines, avoiding negative earnings and avoiding negative earnings surprises (Burgstahler and Dichev 1997; Degeorge, Patel, and Zeckhauser 1999), peer performance is an additional threshold that is often mentioned in news reports, compensation contracts and analysts' reports, while largely ignored in the academic research. Thus, I examine whether firms manage earnings to achieve peer performance. First, I examine accrualsbased earnings management to achieve peer performance. The empirical results show that firms exhibit more income-increasing accruals management in the current year under the following situations: 1) when firms' prior year performance is below that of their peer group; 2) when firms' average performance over the prior two years is below that of its peer group; 3) when firms' expected performance is below its peer group's expected performance. In addition, firms with cumulative performance that is lower than that of its peer group through the first three quarters of the fiscal year exhibit more upward accruals management in the fourth quarter. Second, I investigate real activities manipulation to achieve peer performance. The empirical results show that that firms exhibit more 
income-increasing real activities manipulation in the current year under the following situations: 1) when firms' prior year performance is below that of their peer group; 2) when firms' average performance over the prior two years is below that of its peer group. Third, firms that are under pressure to achieve peer performance benchmarks tend to restate financial statements in subsequent years. Specifically, firms under the following four situations are more likely to restate current earnings in the future: 1) firm's prior year performance is below that of its peer group; 2) firm's average performance over the prior two years is below that of its peer group; 3) firm's expected performance is below that of its peer group; and 4) firm's cumulative performance for the first three fiscal quarters is below that of its peer group. The influence of peer performance on earnings management behavior implies that relative performance evaluation can induce incomeincreasing earnings management and subsequent restatements. 


\section{TABLE OF CONTENTS}

CHAPTER

PAGE

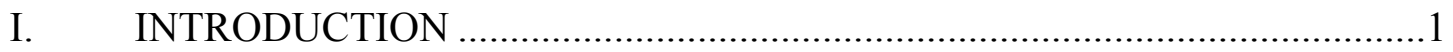

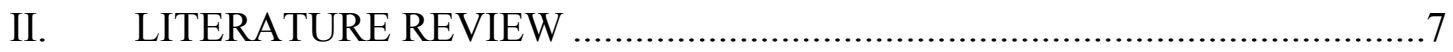

Earnings Management Mechanism..........................................................

Managerial Compensation as Earnings Management Incentives ......................13

Earnings Benchmarks ...............................................................................14

Peer Performance Benchmark......................................................................17

III. HYPOTHESES DEVELOPMENT …………….....................................

Prior Year's Performance below Peer Performance .........................................21

Past Two Year's Mean Performance below Peer Performance.........................22

Current Performance below Expected Peer Performance..................................23

First Three Quarters' Cumulative Performance below Peer Performance ......24

Restatements in Firms Managing Earnings to Achieve Peer Performance .....24

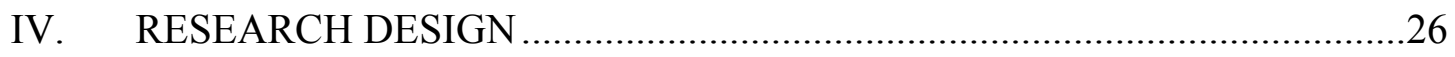

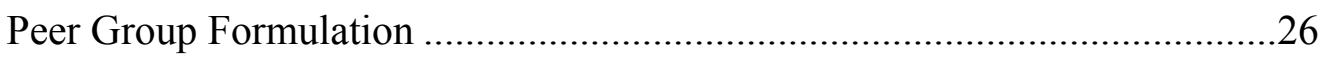

Multivariate Regression Model.................................................................2

Discretionary Accruals Measure as Dependent Variable ..........................27

Real Earnings Management Measure as Dependent Variable.....................29

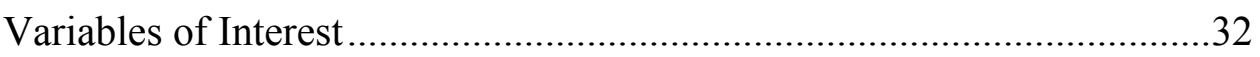

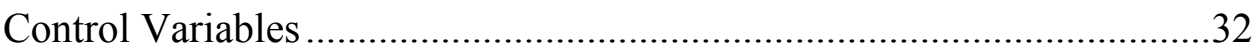

Specific Model for Hypotheses Testing..........................................................

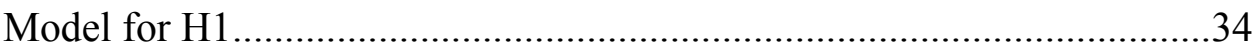

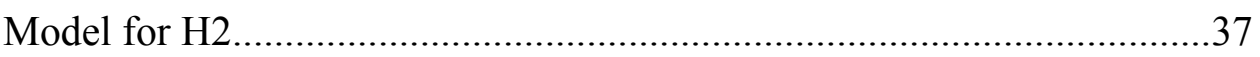

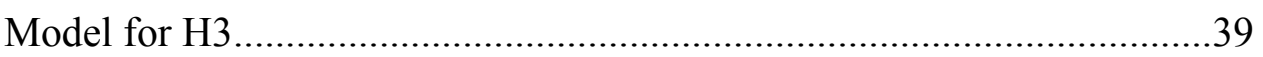

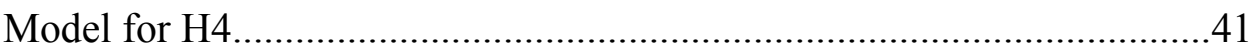

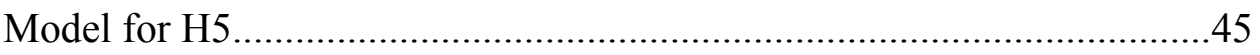

V. SAMPLE SELECTION AND DATA COLLECTION ………………............47

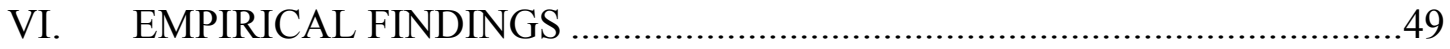




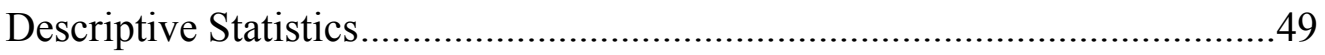

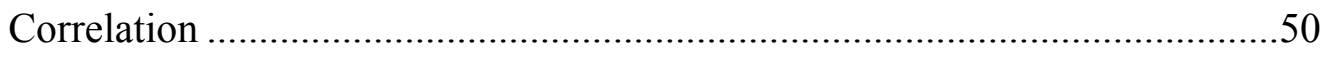

Multiple Regression Analyses ................................................................50

Missing Prior Year's Peer Performance Benchmark ............................50

Missing Prior Two Year's Mean Peer Performance Benchmark...............54

Missing Current Year's Expected Peer Performance Benchmark .............56

Missing First Three Quarter's Cumulated Peer Performance Benchmark 58

Logistic Regression Results ..............................................................60

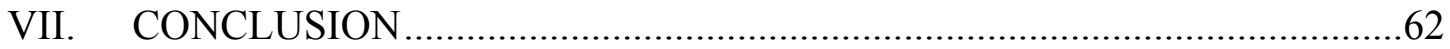

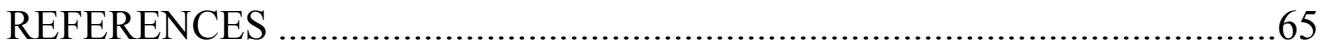

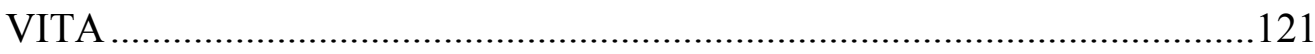




\section{LIST OF TABLES}

TABLE

PAGE

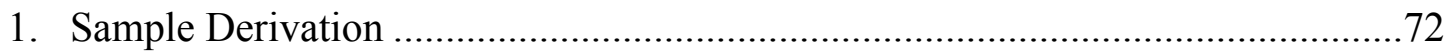

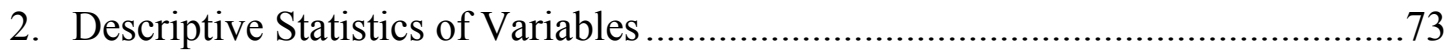

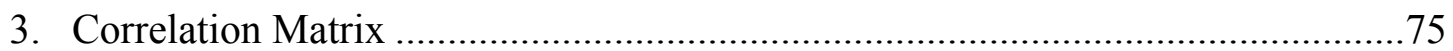

4. Accruals Management of Firms Achieving Current Year's Peer Performance Benchmark

5. Accruals Management of Firms Missing Prior Year's Peer Performance Benchmark

6. Accruals Management of Firms Missing Prior Year's Peer Performance Benchmark and Achieving Current Year's Peer Performance Benchmark

7. Real Earnings Management of Firms Achieving Current Year's Peer Performance Benchmark

8. Real Earnings Management of Firms Missing Prior Year's Peer Performance Benchmark

9. Real Earnings Management of Firms Missing Prior Year's Peer Performance Benchmark and Achieving Current year's Peer Performance Benchmark.

10. Accruals Management of Firms Missing Prior Two Year's Mean Peer Performance Benchmark 
11. Accruals Management of Firms Missing Prior Two Year's Mean Peer Performance Benchmark and Achieving Current Year's Peer Performance Benchmark

12. Real Earnings Management of Firms Missing Prior Two Year's Mean Peer Performance Benchmark

13. Real Earnings Management of Firms Missing Prior Two Year's Mean Peer Performance Benchmark and Achieving Current Year's Peer Performance Benchmark

14. Accruals Management of Firms Missing Current Year's Expected Peer Performance Benchmark

15. Accruals Management of Firms Missing Current Year's Expected Peer Performance Benchmark and Achieving Current Year's Peer Performance Benchmark

16. Real Earnings Management of Firms Missing Current Year's Expected Peer Performance Benchmark

17. Real Earnings Management of Firms Missing Current Year's Expected Peer Performance Benchmark and Achieving Current Year' Peer Performance Benchmark

18. Accruals Management of Firms Missing First Three Quarters' Cumulative Peer Performance Benchmark

19. Accruals Management of Firms Missing First Three Quarters' Cumulative Peer Performance Benchmark and Achieving Current Year's Peer Performance Benchmark 
20. Real Earnings Management of Firms Missing First Three Quarters' Cumulative Peer Performance

21. Real Earnings Management of Firms Missing First Three Quarters' Cumulative Peer Performance and Achieving Current Year's Peer Performance Benchmark

22. Financial Statement Restatement of Firms Achieving Current Year's Peer Performance Benchmark

23. Financial Statement Restatement of Firms Achieving Current Year's Peer Performance Benchmark 108

24. Financial Statement Restatement of Firms Achieving Current Year's and Missing Prior Year's Peer Performance Benchmark

25. Financial Statement Restatement of Firms Achieving Current Year's and Missing Prior Year's Peer Performance Benchmark

26. Financial Statement Restatement of Firms Achieving Current Year's and Missing Prior two Year's Peer Performance Benchmark

27. Financial Statement Restatement of Firms Achieving Current Year's and Missing Prior two Year's Peer Performance Benchmark

28. Financial Statement Restatement of Firms Achieving Current Year's Peer Performance Benchmark and Missing Current Year's Expected Peer Performance Benchmark

29. Financial Statement Restatement of Firms Achieving Current Year's Peer Performance Benchmark and Missing Current Year's Expected Peer Performance Benchmark 
30. Financial Statement Restatement of Firms Missing First Three Quarters' Cumulative Peer Performance Benchmark

31. Financial Statement Restatement of Firms Missing First Three Quarters' Cumulative Peer Performance Benchmark

32. Financial Statement Restatement of Firms Missing Prior Year's Peer Performance Benchmark

33. Financial Statement Restatement of Firms Missing Prior Two Year's Mean Peer Performance Benchmark..........................................................................118

34. Financial Statement Restatement of Firms Missing Current Year's Expected Peer Performance Benchmark

35. Financial Statement Restatement of Firms Missing First Three Quarters' Cumulative Peer Performance Benchmark 


\section{INTRODUCTION}

Prior studies (e.g., Burgstahler and Dichev 1997; Degeorge, Patel, and Zeckhauser 1999) identify three earnings thresholds managers seek to achieve when they report financial statements: avoiding negative earnings, avoiding earnings declines, and avoiding negative earnings surprises. A large number of studies use these three earnings thresholds to test earnings management in various research settings. This dissertation investigates another potential earnings management threshold, peer performance, which has been largely ignored in the extant literature.

Both Burgstahler and Dichev (1997) and Degeorge et al. (1999) explain threshold-driven earnings management behavior by referring to prospect theory (Kahneman and Tversky 1979), which suggests that for a given increase in wealth, the corresponding increase in value is greatest when the increase in wealth moves from negative to positive territory relative to a reference point (viz., zero earnings, zero change in earnings, or zero forecast error). While they do not specifically explain the formulation of reference points or the usage of other reference points beyond those extensively investigated three earnings thresholds, they imply the existence of other reference points (Burgstahler and Dichev 1997). They also suggest that if other reference points are used either by corporate boards or investors, and if those reference points are reflected in the executives' reward or compensation contracts, executives are likely to manage reported earnings in order to meet or beat those reference points (Degeorge et al. 1999). This study examines whether peer performance is another such reference point that managers try to achieve by managing reported earnings. 
Peer firms' performance is widely mentioned as a benchmark in press releases, compensation contracts and analysts' reports. In other words, a firm's performance is often benchmarked against its competitors' performance by analysts, individual investors, institutional investors, compensation committees, and managers. ${ }^{1}$ Prior studies provide substantial evidence that peer firms' performance is benchmarked in setting and implementing executive compensation contracts (e.g., Antle and Smith 1986; Gibbons and Murphy 1990; Barro and Barro, 1990; Garvey and Milbourn, 2003 etc.). More recently, by using an implicit approach based on industry membership and firm size to identify peer firms, Albuqerque (2009) provides consistent evidence of relative performance evaluation (RPE) in the level and change of CEO compensation. Gong, $\mathrm{Li}$ and Shin (2011) use an explicit approach based on proxy disclosures to identify peer firms, and provide evidence of RPE. They also report that about 25 percent of their sample firms explicitly use RPE in setting executive compensation. A typical example of using peer performance as a benchmark can be observed in the following excerpt from the 2014 proxy statement of Analog Devices. Inc.,

"In setting our targets, we use an assessment of our business results relative to our peers to ensure that our performance targets are appropriately calibrated. Our Compensation Committee's independent consultant, PM\&P, conducted an analysis, which compared our performance against the five-year average

\footnotetext{
${ }^{1}$ For example, an article in The Wall Street Journal on May 2, 2015 states, "The lending club is getting awfully crowded. On Tuesday, LendingClub Corp. posted earnings above expectations, reporting a surge in new loans, even as it cited growing congestion in the industry. Like OnDeck Capital, another online lender that reported earnings this week, LendingClub said it was spending large sums to advertise to new customers and stand out in an increasingly packed marketplace. Neither company recorded a profitLendingClub posted a loss of $\$ 6.4$ million in the first quarter while OnDeck said it lost $\$ 5.3$ million-but the rapid loan growth the lenders reported illustrates why others are rushing to the sector."
} 
performance of our peers, including revenue growth and operating profits to help us determine the appropriate targets for fiscal 2013...”

Besides compensation, prior research also suggests that executives are concerned about their career when their firm performs below industry peer performance, because RPE is used in CEO turnover decisions. Rajgopal, Shevlin, and Zamora (2006) document that a CEO's outside career opportunities depend on his/her firm's performance relative to industry peer performance. Moreover, board of directors' ability to identify relatively incompetent CEOs increases with the use of RPE. DeFond and Park (1999) document that CEO turnover is associated with RPE-based accounting measures (industry-adjusted earnings). Thus, peer performance can influence CEO careers. Financial analysts use peer firms to compare performance and to support their valuation multiples, earnings forecasts, and overall stock recommendations (e.g., Bradshaw 2011). Analysts' choice of peer firms has prompted the attention of academic researchers. De Franco, Hope, and Larcoque (2012) find that sell-side equity analysts select peer firms with high valuation multiples. Other groups, such as individual investors and fund managers, also use peer firms in their investing decisions. Financial statement analysis textbooks routinely recommend the use of peer firms in business valuation processes (Healy and Palepu 2007; Stickney, Brown, and Wahlen 2007; Damondaran 2009). Investors use peer firms to judge the merits and comparability of investments (De Franco, Kothari, and Verdi 2011). Fund managers use peer firms in structuring their investment portfolios (Chan, Lakonishok, and Swaminathan 2007).

Thus, managers have incentives to achieve or exceed peer performance. I examine whether managers engage in income-increasing earnings management when they face 
pressure to achieve peer performance. I develop hypotheses based on firms' prior performance, current expected performance, and current interim quarters' performance relative to their peer group. I argue that firms manage current year reported earnings when the prior year's performance (or the average of the prior two years' performance) is lower than the peer group. I use these windows because, in many cases, compensation contracts are based on three year's relative metrics. ${ }^{2}$ I also argue that if a firm's expected performance for the current year is lower than that of its peer group, they are likely to manage earnings upward. I then conjecture firms manage fourth quarter's earnings upward when the first three quarters' cumulative performance is lower than that of its peer group.

I identify the peer group based on industry-size quartile following Albuquerque (2009). I test my hypotheses by conducting analyses of both accruals and real earnings management. To examine accruals management, I use two proxies for discretionary accruals, abnormal total accruals $(A T A)$ and abnormal current accruals $(A C A)$, which are measured using a version of the Modified Jones Model (Dechow, Sloan, and Sweeney 1995 ) adjusted for performance (Kothari, Leone, and Wasley 2005). I use two proxies for real activities manipulation, unexpected abnormal level of discretionary expenditures ( $r m U D I S X)$ following Zang (2012), and abnormal cash flow from operations ( $\mathrm{rmCASH}$ ) following Roychowdhury (2006). After providing evidence that firms engage in incomeincreasing earnings management to achieve peer performance, I show that firms

\footnotetext{
${ }^{2}$ For example, excerpt from 2014 proxy statement of Avery Dennison Corporation states, "As discussed in further detail in Compensation Discussion and Analysis, the performance units granted under both the 2008-2010 Mid-Term Incentive Plan ("MTIP") and the 2009-2011 MTIP were cancelled because we did not meet the threshold level for the applicable performance objectives. Multi-year vesting and performance periods promote stockholder value creation and long-term growth."
} 
associated with income-increasing earnings management to achieve peer performance are more likely to restate their financial statements subsequently.

The empirical results show that firms exhibit more income-increasing accruals management in the current year under the following situations: 1) when firms' prior year performance is below that of their peer group; 2) when firms' average performance over the prior two years is below that of its peer group; 3) when firms' expected performance is below its peer group's expected performance. In addition, firms with cumulative performance that is lower than that of its peer group through the first three quarters of the fiscal year exhibit more upward accruals management in the fourth quarter.

Next, I examine real activities manipulation to achieve peer performance. The empirical results show that that firms exhibit more increase-increasing real activities manipulation in the current year under the following situations: 1) when firms' prior year performance is below that of their peer group; 2) when firms' average performance over the prior two years is below that of its peer group.

I do not find evidence consistent with firms using real activities manipulation when firms' expected performance is below its peer group's expected performance. One possible explanation could be that it takes time to manipulate real activities, such as offering price discounts, engaging in overproduction, and reducing discretionary expenditures aggressively (Roychowdhury 2006). In addition, the real activities manipulation must occur during the fiscal year, while accruals can be managed even after the fiscal year-end (Zang 2012). Firms compare their performance to the expected peer performance at the end of the fiscal year to determine the extent of earnings management, when it is not possible to manipulate real activities. 
In addition, contrary to my expectation, the empirical results show that firms with cumulative performance that is lower than that of its peer group through the first three quarters of the fiscal year exhibit more downward real activities manipulation in the fourth quarter. One possible explanation could be that managers adjust the level of accrual-based earnings management according to the level of real activities manipulation. Thus, there is a negative relation between the amount of accrual-based earnings management and the amount of unexpected real activities manipulation (Zang 2012). I observe a positive correlation between accruals management in the fourth quarter and firms with cumulative performance that is lower than that of its peer group through the first three quarters of the fiscal year. Thus, I observe a negative correlation between real earnings management in the fourth quarter and firms with cumulative performance that is lower than that of its peer group through the first three quarters of the fiscal year.

Finally, I also investigate the likelihood of future restatements of financial statements for firm-year observations that are subject to earnings management to achieve peer performance. Restatements of financial statements is a consequence of prior earnings management. I find that firms under the following four situations are more likely to restate current earnings in the future: 1) Firm's prior year performance is below that of its peer group; 2) Firm's average performance over the prior two years is below that of its peer group; 3) Firm's expected performance is below that of its peer group; 4) Firm's cumulative performance of the first three quarters is below that of its peer group.

In this dissertation, I provide empirical evidence that managers engage in earnings management to achieve peer performance. My research makes the following contributions. First, this study adds another earnings benchmark, peer performance, 
which managers seek to achieve, and which has been largely ignored in the extant literature on earnings management, although it has been used in RPE for compensation contracts. Second, this study extends the existing literature on the roles that peer firms play in influencing operating and financial policies. Leary and Roberts (2014) show, for example, that peer firms play an important role in determining corporate capital structure and financial policies. Prior studies also show firms' fraudulent reporting influence peer firms' investment decisions (Beatty, Liao, and Yu 2013), reporting decisions (Kedia, Koh, and Rajgopal 2015), and research and development, and advertising expenditure decisions (Li 2015). My research shows that peer firms' performance also has an impact on earnings management decisions. Finally, the findings in this study indicate that although the RPE can improve compensation contracts and enhance the efficiency of compensation plans, it can have unintended consequences as it may induce incomeincreasing earnings management.

The rest of this dissertation is organized as follows. Section II reviews the literature. Section III develops hypotheses. Section IV describes the research design. Section V describes the sample selection procedure and data requirements. Empirical findings are discussed in Section VI. Section VII concludes this study.

\section{LITERATURE REVIEW}

I begin with reviewing the earnings management literature in general and prior studies on earnings management mechanisms. I then discuss studies documenting 
empirical evidence relating to incentives for earnings management with a focus on executive compensation. Finally I review prior studies on earnings benchmarks before suggesting peer performance as a potential earnings threshold for managing earnings. Healy and Wahlen (1999) define earnings management as below,

"Earnings management occurs when managers use judgment in financial reporting and in structuring transactions to alter financial reports to either mislead some stakeholders about the underlying economic performance of the company or to influence contractual outcomes that depend on reported accounting numbers."

\section{Earnings Management Mechanisms}

Prior accounting research provides evidence of three main mechanisms that managers use to manage earnings: accruals management, real activity management, and classification shifting. Accruals management is the most widely used mechanism, and the extant accounting literature extensively provides evidence of this earnings management tool. Under this mechanism, managers exercise their discretion over accounting accruals when reporting financial statements. Healy (1985) uses total accruals as a proxy for discretionary accruals and documents that managers adopt certain accruals policies, income-increasing and income decreasing accruals, to maximize their bonus. Subsequent studies further refine the measure of discretionary accruals, and provides evidence of earnings management using accruals. Jones (1991) develops an expectation model of nondiscretionary accruals as a function of changes in revenues and the level of property, plant and equipment, and documents that managers resort to income-decreasing discretionary accruals to take advantage of import relief announced by government. Teoh, 
Wong, and Rao (1998) examine abnormal accruals at the issue-year and during a longrun period after the IPO-year. They find high IPO-year abnormal accruals and low postIPO earnings performance compared to industry peers among those firms. Following Jones model of discretionary accruals, Perry and Williams (1994) compared the discretionary accruals of management buyout firms with a set of control firms. They find that prior to the announcement of the management buyout proposal, the discretionary accruals of those firms are lower than the control firms, suggesting earnings were managed downward.

Dechow et al. (1995) refine the Jones model by taking out changes in receivables from the changes in revenue because changes in receivables are also exposed to accruals management. Dechow and Dichev (2002) derive a measure of accruals quality that is based on accrual estimation error, which can be driven by intentional accruals management or unintentional mistakes in estimation. Kothari, Leone, and Wasley (2005) suggest matching the discretionary accruals, calculated from the modified Jones model, to a firm within the same industry by performance, which is widely known as performance-matched discretionary accruals. Although the models listed above are widely used in the extant literature, scholars still question the specification of and power of these models.

Filing a restatement due to the fact that the prior financial statements were not in accordance with generally accepted accounting principles (GAAP), is the most visible indicator of improper accounting, according to the Securities and Exchange Commission (SEC). When GAAP violations are committed through accruals manipulations, abnormal 
accruals can be linked to restatement, an indicator that firms adopted aggressive accounting policies. Studies suggest there is a positive relationship between accruals and the likelihood of restatements. As early as Dechow, Sloan, and Sweeney (1996), research documents that firms subject to accounting enforcement actions by the SEC have higher total accruals and discretionary accruals. Dechow, Ge, Larson, and Sloan (2011) describe the process of how accruals management develops into aggressive manipulation. Because there is a certain flexibility within GAAP, managers resort to aggressive manipulation after they run out of that flexibility. In many cases, aggressive manipulations of accounting accruals result into future restatements. In this dissertation, I use the restatement as the consequence of prior accruals management.

Under real earnings management managers manipulate earnings through investment and operational activities, which have an impact mostly on cash flows. Roychowdhury (2006) defines such real activities manipulation as "management actions that deviate from normal business practices, undertaken with the primary objective of meeting certain earnings thresholds." Evidence of managing investment activities can be traced back to the research on research and development (R\&D) expenditures. Baber, Fairfield, and Haggard (1991) find that managers reduce the R\&D spending in the current period to reach positive income or to report an increasing trend of income.. Dechow and Sloan (1991) document that CEOs reduce R\&D expenditures prior to their departure from firm in order to reach a higher compensation level through the earnings-based bonus plan.. Operational activities, such as advertising and maintenance costs, overproducing to decrease cost of goods sold, are used to manipulate earnings as well. In the Graham, Harvey, and Rajgopal (2005) survery of 401 financial executives, $80 \%$ of them agree 
with manipulating expenditures on $\mathrm{R} \& \mathrm{D}$, advertising and maintenance to achieve earnings benchmarks. Roychowdhury (2006) developed models to estimate the level of cash flow manipulation, the level of over-production, and the level of discretionary expenditures such as R\&D, advertising, and maintenance.

Misclassification of items within the income statement, to inflate or deflate subtotals (i.e., core earnings, operating earnings, noncore expenses) without affecting the bottom line net income, is another type of earnings management mechanism. Since core expenses and special items are reported in the income statement separately, and analysts' mainly focus on core earnings, managers shift core expenses to special items to meet analysts' annual forecasts. (McVay 2006). Kinney and Trezevant (1997) state that firms use income-decreasing special items to keep an increasing trend of core earnings. By developing a model that captures unexpected core earnings, McVay (2006) finds a positive relation between unexpected core earnings and the magnitude of incomedecreasing special items, which is consistent with shifting core expenses to special items Because of the innate problem that accruals include accrual special items, it is problematic to condition core earnings expectations on contemporaneous accruals (McVay 2006), Fan, Barua, Cready, and Thomas (2010) exclude contemporaneous accruals from the core earnings expectation model and augment the model by adding a return variable as a proxy for performance. By using quarterly data, and analyzing incentives such as meeting or beating analysts' forecasts and flexibility in accruals management, they provide consistent evidence of classification shifting under specific settings, such as in the fourth quarter compared to the interim quarters. Other than the classification of special items, Barua, Lin, and Sbaraglia (2010) investigate the 
classification shifting of core expenses to discontinued operations. They find firms move core expenses to discontinued operations to increase core earnings. One of the motivations for such shifting is to meet or beat analysts' forecasts. In an international setting, Haw, Ho, and Li (2011) use East-Asia economic data and find consistent results with McVay (2006). In addition, they find firms with family controlling shareholders are engaged in a higher level of expense misclassification, suggesting concentrated ownership structures play an important role in the level of misclassification shifting. In addition to misclassification of items within the income statement, firms can also engage in misclassification of items within the cash flow statement. Lee (2012) examines the misclassification of cash flows in specific settings, such as classifying tax benefits as operating cash flows.

A stream of research studies the substitutions and preferences by managers among different earnings management mechanisms. Zang (2012) investigates whether managers trade-off between real activities manipulation and accruals management. They find that the relationship between the level of real activities manipulation and the level of accruals management is significant and negative, after controlling for the costs of real activities manipulation and the costs of accruals management. Cohen, Dey, and Lys (2008) investigate the level of real activities manipulation and accruals management before and after the passage of Sarbanes-Oxley Act (SOX). They find that firms manage earnings to reach benchmarks before and after the passage SOX, yet accruals management is used less in the post-SOX period and the level of real earnings management is higher in the post-SOX period. Fan et al. (2010) find that classification shifting is more profound when the ability of managers to manipulate accruals is constrained. Graham, Harvey, and 
Rajgopal (2005) find that only $7.9 \%$ of their survey participants choose to alter accounting assumptions if they are below the desired target while $79.9 \%$ choose to decrease discretionary spending. Badertscher (2011) studies the relationship between firm's duration of overvaluation and its earnings management choices. He finds that overvaluation initially drives firms to engage in accruals management, then they switch to real activities manipulation after running out of accruals management flexibility.

\section{Managerial Compensation as Earnings Management Incentives}

Prior studies examining compensation contracts as earnings management incentives shows that managers use accounting judgement to increase or decrease earnings to maximize their wealth. Early accounting research recognizes that because accounting numbers are used in compensation, accounting choices affect wealth, and thus affect agency costs (Watts and Zimmerman 1990). Healy (1985) finds that the direction of accruals management is contingent on the bonus plan. When the bonus plan's upper bound is exceeded reached or the lower bound cannot be reached, the proportion of negative accruals are much larger compared to the rest of the sample. Guidary, Leone, and Rock (1998) use business unit-level data to test whether managers use discretionary accruals to maximize their short-term bonuses. Holthausen, Larcker, and Sloan (1995) show that firms report accruals that defer income when their bonuses are at their maximum. In addition to research on bonus plans in compensation contracts, some research focuses on the stock-based and option-based compensation. Warfield, Wild, and Wild (1994) find a negative association between abnormal accruals and managerial 
ownership, suggesting managerial ownership reduces the incentives for opportunistic behavior by managers. Bergstresser and Philippon (2006) show that managers build up large positive abnormal accruals during the period when they exercise options and sell their firm shares. Burns and Kedia (2006) examine whether stock options in compensation contracts provide incentives to adopt aggressive accounting practices. They find that the sensitivity of CEO wealth to stock price, arising from the CEO's option holdings, is positively related to the probability of misreporting. But they find no evidence that incentives from equity and restricted stock, and long-term incentive payouts are associated with misreporting. Efendi, Srivastava, and Swanson (2007) find that compared with a control sample matched on industry, size, and time, a CEO with a sizeable amount of in-the-money stock options will largely increase the likelihood of misstatement. In contrast with other studies on equity incentives, after matching CEOs on the observable characteristics of their contracting environments using a propensity matching score approach, Armstrong, Jagolinzer, and Larcker (2010) find no evidence of a negative association between accounting restatements and the level of CEO equity incentives.

\section{Earnings Benchmarks}

Burgstahler and Dichev (1997) and Degeorge et al. (1999) identify three earnings thresholds — avoiding losses, avoiding earnings declines and avoiding negative earnings surprises. Since then numerous studies (Brown and Caylor 2005; Kasznik and McNichols 
2002; Dechow, Richardson, and Tuna 2003; Barth, Elliott, and Finn 1999) use these earnings thresholds to investigate earnings management in various settings.

Findings on whether small profits and small loss avoidance represent earnings management are mixed. Some studies find no evidence of a discontinuity at zero in the distribution of earnings. Dechow, Richardson, and Tuna (2003) investigate whether management of discretionary accruals to report a small profit is a reasonable explanation for the earnings distribution that too few firms report small losses and too many firms report small profits. They find that discretionary accruals are similar in both the small profit group and the small loss group. Beaver, McNichols, and Nelson (2007) find that the discontinuity at zero in the distribution of earnings is due to the asymmetric effects of income taxes and special items for profit and loss firms. Durtschi and Easton (2005) provide evidence that the discontinuity at zero in the distribution of earnings is affected by deflation, sample selection criteria that led to differential inclusion or exclusion of observations to the left of zero versus observations to the right of zero, and differences between the characteristics of observations to the left of zero and observations to the right of zero.

Some studies confirm the finding in Burgstahler and Dichev (1997). Jacob and Jorgensen (2007) aggregate quarterly earnings over annual periods that differ from the fiscal year and compare the distribution of these alternative annual earnings with those of fiscal year earnings. They find that annual earnings computed using the alternative aggregation periods do not exhibit a discontinuity around zero, thus suggesting that earnings management is responsible for the discontinuity. Beaver, McNichols, and Nelson (2003) document that property-casualty insurers understate loss reserves in order 
to reach the zero earnings benchmark. Phillips, Pincus, and Rego (2003) examine the usefulness of deferred tax expense as compared to other accrual measures in detecting earnings management. They suggest that deferred tax expense is more useful than other accruals measures in detecting earnings management to meet the avoiding loss benchmark. Kerstein and Rai (2007) show that a high proportion of firms with small cumulative profits or losses at the beginning of the fourth-quarter report small annual profits rather than small annual losses, compared to a control group, which consisted of firms in the earnings distribution next to treatment group.

In terms of evidence that earnings are likely managed to avoid negative earnings surprises, Ayers, Jiang, and Yeung (2006) suggest that the positive association between discretionary accruals and beating the benchmark extends to pseudo targets (i.e. points other than the zero in the distributions of earnings, earnings changes, and analysts-based unexpected earnings) derived from the earnings distribution as well as earnings change distribution, but few positive associations was found between discretionary accruals and beating pseudo targets derived from analysts-based unexpected earnings distribution. Hribar, Jenkins, and Johnson (2006) find that firms use stock repurchases to increase earnings per share to meet or beat analysts' earnings per share forecasts.

Another stream of research examines the motivations associated with the target beating. Capital market valuation seems to be the most dominant motivation to achieve earnings thresholds (Matsumoto 2002; Bartov, Givoly, and Hayn. 2002; Kasznik and McNichols 2002; Lopez and Rees 2002; Skinner and Sloan 2002). Graham et al. (2005) indicates that managers view capital market valuation as one of the main reasons for achieving earnings thresholds, they also offer other motivations - smoothing earnings, 
reducing stock price volatility, signaling about growth prospects, achieving desired credit rating, external reputation of management, and earning bonuses. Cheng and Warfield (2005) find that managers with high equity incentives (i.e. arising from stock-based compensation and stock ownership) are more likely to report earnings that meet or just beat analysts' forecasts and less likely to report large positive earnings surprises.

\section{Peer Performance Benchmark}

Peer firms' performance has been used as a benchmark in evaluating and compensating corporate executives. Holmstrom (1982) develops a model to describe the theory of relative performance evaluation (RPE). This theory suggests that the efficiency of a contract with an agent can be improved by incorporating the performance of agents exposed to similar business risk. Thus the RPE provides better risk sharing. Since then, many papers test whether top corporate executives are compensated as if their performance is evaluated relative to the performance of the company's competitors. Antle and Smith (1986) was the first paper that tested this hypothesis. Their results are mixed. They find weak support for the use of RPE in the total compensation contracts of 16 out of 39 firms in the chemical, aerospace, and electronics industries during 1947 to 1977. Barro and Barro (1990) study the relative performance evaluation for CEOs of banks. Their results suggest that cash compensation is not adjusted for a regional average of bank performance in their sample of 83 banks during 1982-1987. Gibbons and Murphy (1990) find evidence supporting weak form of RPE using stock returns as the performance measure in the compensation contract but no evidence for peer-group accounting performance (ROA). Janakiraman, Lambert and Larcker (1992) find similar 
results. Aggarwal and Samwick (1999a) find evidence of RPE when compensation is defined in levels, but fail to find evidence when using changes in compensation.

Several explanations have been provided for the mixed evidence. Bertrand and Mullainathan (2001) argue that CEOs are rewarded for luck, i.e., changes in firm performance that are beyond the CEO's control. Their findings suggest that better governed firms pay their CEO less for luck. Aggarwal and Samwick (1999b) show that RPE is used less in more concentrated industries. Himmelberg and Hubbard (2000) argue that a manager's outside job opportunities are a positive function of industry stock returns and that this is stronger for more talented CEOs. Garvey and Milbourn (2003) argue that, in general, executives can replicate in their private portfolios an indexation that removes the influence of market-wide factors. But this ability to remove excessive market risk is constrained by wealth and human capital. Thus there is little RPE for the average executives, but there is strong evidence of RPE for younger and less wealthy managers. Rajgopal et al. (2006) find that the lack of RPE is due to the fact that CEO pay varies with outside employment opportunities. Albuquerque (2009) argues that the mixed empirical evidence on the use of RPE is due to miss-specified peer groups. She suggests to form peer groups with similar industry-size firms.

\section{HYPOTHESES DEVELOPMENT}

The main focus of this study is to investigate empirically whether firms consider peer performance as another earnings benchmark that they try to achieve using 
managerial discretion in financial reporting process. Managers have earnings management incentives to reach peer performance in either of these two conditions: 1) when relative performance evaluation (RPE) is used in compensation and/or dismissal decisions, and 2) when analysts and investors use peer performance in their valuation and investing decisions.

With respect to the first condition, Holmstrom (1982) states that an incentive scheme based on relative performance is superior to an incentive scheme based on individual performance. RPE provides insurance against external shocks and yields a more informative measure of CEO actions. Empirical results provided in Albuqerque (2009), Gong et al. (2011), and Albuqerque (2014) support the use of RPE in CEO compensation contracts. Albuquerque (2009) states that firms of different sizes are exposed to different shocks and face different constraints in responding to those shocks. Her results show systematic evidence supporting the implicit RPE usage in CEO compensation schemes when peer groups consist of firms within the same industry and size quartile. Gong et al. (2011) examine the explicit use of RPE in executive compensation contracts and find that about 25 percent of S\&P 1500 firms explicitly used RPE in 2006. Albuqerque (2014) finds that the implicit use of RPE in CEO compensation contracts varies negatively with a firm's growth options (i.e. the proxies for growth options in Albuqerque 2014 are market-to-book ratio, $R \& D$ expenses to assets, and the ratio of advertising expenses to assets). Other than CEO pay, RPE is also used by the board of directors in CEO turnover decisions. DeFond and Park (1999) find that CEO turnover is negatively associated with the level of competition in industries, which 
suggests that boards of directors in highly competitive industries use RPE to identify and replace poorly performing CEOs.

With respect to the second condition, empirical evidence suggests that investors and analysts use peer performance in their valuation decision. Analysts often use peers to compare performance across firms as well as to estimate the market values of the firms they cover. De Franco et al. (2012) examine how peers are chosen in practice by manually extracting information on peer firms from analysts' reports. They show that analysts are more likely to choose peer firms that are similar in size, leverage, asset turnover, industry classification and trading volume. Bhojraj and Lee (2002) develop a systematic approach for the selection of comparable firms. They argue that the choice of comparable firms should be a function of the variables that drive cross-sectional variation in a given valuation multiple. Those variables include profitability, growth, and the costof-capital. De Franco et al. (2011) suggest that analysts use comparable peers in their reports to evaluate the current firm valuation multiples or justify the predicted firm valuation multiples. Thus, prior research provides support for the conjecture that managers are likely to manage earnings upward to reach peer performance.

One of the commonly used earnings management mechanisms is accruals management. The extant literature provides substantial evidence that managers use discretionary accruals to achieve earnings benchmarks when they report financial information (Payne and Robb 2000; Matsumoto 2002; Burgstahler and Eames 2006). Payne and Robb (2002) provide evidence consistent with firms managing abnormal accruals when pre-managed earnings fall short of analysts' expectations. Matsumoto (2002) also finds consistent evidence that accruals are managed upward to avoid negative 
earnings surprises. For specific accruals, Beaver et al. (2003) find that property-casualty insurers with small positive earnings understate loss reserves relative to insurers with small negative earnings. Loss reserves are managed across the entire distribution of earnings, with the most income-increasing reserve accruals reported by small profit firms, and the most income-decreasing reserve accruals reported by firms with the highest earnings.

Prior studies (e.g., Roychowdhury 2006, Graham et al. 2005) also provide evidence that managers engage in real activity management to achieve earnings benchmarks. Examples of real activity management include reduction of prices to increase sales, overproduction to reduce costs of goods sold, reduction of discretionary expenses (Roychowdhury 2006), and reduction of research and development (R\&D) expenses (Baber et al. 1991; Dechow and Sloan 1991; Bushee 1998).

If managers use discretionary accruals and manipulate real activities to manage earnings upward to achieve peer performance, I expect to observe higher levels of discretionary accruals and real earning management under the following situations: 1) Firm's prior year's performance is below that of its peer group; 2) Firm's past two year's average performance is below that of its peer group; 3) Firm's expected current year's performance is below that of its peer group; 4) Firm's first three quarters' cumulative performance is below that of its peer group.

\section{Prior Year's Performance below Peer Performance}

When firms fail to meet peer performance benchmarks in the prior year, managers face increasing pressure to reach peer performance in the current year. The pressure is 
stimulated by the fear of losing compensation, reputation and career prospects. Merchant (1989), for example, argues that managers who miss financial targets are more concerned with the associated loss of credibility and intervention than with reductions in bonus compensation.

Compensation contracts usually contain long-term provisions. Bed Bath \& Beyond Inc., for example, states in their 2014 proxy statement that "performance during the three-year period will be based on Return on Invested Capital relative to such peer group." If the firm fails to reach peer performance in the first year, it still has a chance to meet and beat peer performance in a three-year period if the firm performs better than its peers in total over the performance measurement window. Thus, managers of firms with prior year performance below that of their peers have greater incentives to manage earnings upward. I operationalize earnings management through income increasing abnormal accruals and real earnings management, thus formally, my hypothesis is:

H1: Firms with prior year performance below their peer group will exhibit greater levels of income-increasing earnings management in the current year.

\section{Past Two Year's Mean Performance below Peer Performance}

Allen, Larson, and Sloan (2013) show that "good" accruals relating to temporary fluctuations in working capital reverse over adjacent fiscal years. Thus, with respect to accruals management, my first hypothesis can be affected by the normal reversal of accruals. DeFond and Park (1997) suggest that when managers are not satisfied with current earnings and they expect future earnings to be good, managers use part of the future earnings for the current period. To address this concern, my second hypothesis is 
based on the average performance of the previous two years. More importantly, long term incentive awards in compensation contracts are usually earned over a three to five year period. Allegion Inc. (2014) states, for example, that "Performance Share Program is earned over a 3 year performance period. Equity earned is based on our EPS growth (from continuing operations) relative to companies in the S\&P 500 Industrials Index". In this case, relative average performance is used in the decision making process.

My second hypothesize is thus:

H2: If a firm's average performance over the prior two years is below its peer group, it will have more income-increasing earnings management in the current year.

\section{Current Performance below Expected Peer Performance}

When a firm's expected current year performance is worse than its peer group, the firm managers are likely to strive to reach peer performance. I employ analysts’ consensus forecasts as my proxy for expected current year performance. Prior studies (Abarbanell and Lehavy 2003; DeFond and Park 1997; and Elgers, Pfeiffer and Porter 2003) argue that analysts' forecasts can also be proxies for unmanaged earnings. Since managers may not know peer firms' earnings at the time they make real earnings or accruals decisions, they are likely to rely on analysts' forecasts of peer firm performance. Managers are thus likely to manage earnings upward when faced with the potential underperformance relative to their peers. Formally, I hypothesize that:

H3: If a firm's expected performance is below its peer group's expected performance, it is likely to engage in income-increasing earnings management in the current year. 


\section{First Three Quarters' Cumulative Performance below Peer Performance}

Prior accounting research suggests that firms have greater incentives to manage earnings in the fourth quarter of the fiscal year because managers are likely to have a good sense of where they stand vis-à-vis annual targets (Dechow and Shakespeare 2009). Jacob and Jorgensen (2007) state that managers are unlikely to be evaluated based on earnings for interim periods and, thus, they have weaker incentives to manage the first three quarters of a fiscal year's earnings. Kerstein and Rai (2007) show that a high proportion of firms with small cumulative profits or losses at the beginning of the fourth quarter report small annual profits rather than small annual losses. The fourth quarter represents a manager's last opportunity to manage earnings, and it also provides managers the latest earnings information upon which to base their earnings management targets. Thus, I hypothesize that if firms' cumulative performance in the first three quarters of their fiscal year is below its peer group, they will have greater incentives to manage earnings upward. Stated formally, my hypothesis is:

H4: Firm's with cumulative performance lower than its peer group through the first three quarters of the fiscal year will exhibit more upward earnings management in the fourth quarter of their fiscal year.

\section{Restatements in Firms Managing Earnings to Achieve Peer Performance}

Prior studies suggest that there is a positive relation between accounting accruals and the likelihood of restatements. Richardson, Tuna, and Wu (2002) provide evidence that restatement firms have high levels of accruals in the years of alleged manipulation. 
Desai, Krishnamurthy, and Venkataraman (2006) provide complementary support for the positive relation between the level of accruals and the propensity to restate by demonstrating that short sellers accumulate positions in restatement firms several months in advance of the restatement announcement, and the increase in short interest is larger for firms with high levels of accruals prior to restatements. Hennes, Leone, and Miller (2008) stress the importance of separating errors from irregularities in misreporting, as earnings management is the major cause of restatements caused by irregularity. On the other hand, Ettredge, Scholz, Smith, and Sun (2010) argue that some errors, appearing to be unintentional, are the result of earnings management. They find that firms with apparently non-fraudulent errors show a systematic accumulation of income-increasing accounting choices leading to the restatement period. When within-GAAP earnings management options have been exhausted, companies can choose to either miss earnings targets (Barton and Simko 2002) ${ }^{3}$, or resort to the most egregious form of earnings management - non-GAAP earnings management. Thus, firms with higher incentives to achieve peer performance are more likely to turn to non-GAAP earnings management as a last resort. I hypothesize that firms that are under pressure to achieve peer performance benchmarks will be subject to subsequent restatements. Thus, my next set of hypotheses are:

H5A: If firm's prior year's performance is lower than its peer group, its current year's earnings are more likely to be restated in the future.

\footnotetext{
${ }^{3}$ Barton and Simko (2002) show that companies with constrained balance sheets are more likely to miss earnings targets.
} 
H5B: If firm's average performance of the past two years is lower than its peer group, its current year's earnings are more likely to be restated in the future.

H5C: If firm's expected performance is below its peer group's expected performance, its earnings are more likely to be restated in the future.

H5D: If firm's cumulative performance of first three quarters is below its peer group, its earnings are more likely to be restated in the future.

\section{RESEARCH DESIGN}

This section describes the research design that I employ in investigating whether firms manage earnings to achieve peer performance. My research design includes methods of identifying peer groups for each firm, multivariate regression models used in testing the hypotheses, and methods of measuring dependent variables, variables of interest, and control variables.

\section{Peer Group Formulation}

Prior studies use different approaches to identify peer groups for RPE, and empirical findings relating to RPE vary across the studies depending on the approaches used to identify peer firms in those studies (Gibbons and Murphy 1990; Baker 2002). Given the lack of consensus on one best approach, I follow Albuquerque 2009 in identifying peer groups. 
The peer group is constructed based on the two-digit standard industry classification code (SIC) and firm size quartile within the two-digit SIC level. First, within an industry (two-digit SIC), firms are sorted by beginning-of-year market value to form size quartiles. Second, each firm is matched with an industry-size quartile peer group excluding the firm. Third, the median of performance, measured as return on assets $(R O A)$ in each peer group, is identified as peer performance.

\section{Multivariate Regression Model}

To test my hypotheses, I use the following base model that includes fundamental factors, such as size, growth, leverage, and performance, that are known to explain earnings management decisions, and a binary variable: Miss, that equals one if the firm's historical performance or current estimated performance is below that of its peer group. $E M=\alpha_{0}+\alpha_{1}$ Miss + Control Variables + IndDummies + YearDummies $+\varepsilon_{i t}$

\section{Discretionary Accruals Measure as Dependent Variable}

I use two proxies for discretionary accruals, abnormal total accruals $(A T A)$ and abnormal current accruals $(A C A)$. The first proxy $A T A$ is the firm-specific residuals derived from the following equation (2) estimated cross-sectionally for each industryyear combination. Equation (2) is a version of the Modified Jones Model augmented with lagged ROA as an additional explanatory variable following Kothari, Leone, and Wasley (2005). 
$\frac{T A_{i t}}{A_{i t-1}}=\varphi_{0}+\varphi_{1}\left(\frac{1}{A_{i t-1}}\right)+\varphi_{2}\left(\frac{\Delta R E V_{i t}}{A_{i t-1}}-\frac{\Delta R E C_{i t}}{A_{i t-1}}\right)+\varphi_{3}\left(\frac{P P E_{i t}}{A_{i t-1}}\right)+R O A_{t-1}+\varepsilon_{i t}$

$T A$ is total accruals measured as the difference between income before extraordinary items and cash flows from operations excluding cash flows from extraordinary items and discontinued operations. $\triangle R E V_{i t}$ is change in revenues from year $t-1$ to year $t$ for firm $i . \triangle R E C_{i t}$ is the change in receivables from year $t-1$ to year $t$ for firm i. $P P E_{i t}$ is gross property plant and equipment of firm $i$ for year $t . R O A_{t-1}$ is the return on assets of firm $i$ for year $t-1 . A_{i t-1}$ is total assets of firm $i$ for year $t-1$;

Prior studies (Guenther 1994; Teoh, Welch, and Wong 1998; Bradshaw, Richardson, and Sloan 2001; Ashbaugh, LaFond, and Mayhew 2003) suggest that current accruals are subject to more managerial discretion compared to long-term accruals that include depreciation, depletion and amortization expenses. Thus, for the empirical tests, I also employ abnormal current accruals $(A C A)$ defined as the firm specific residuals from equation (3) estimated cross-sectionally for each year-industry combination. Equation (3) is another version of the Modified Jones Model using current accruals as the dependent variable and dropping PPE from the right-hand side following Ashbaugh et al. (2003). Consistent with equation (2), I also include lagged $R O A$ as an additional explanatory variable in the model.

$\frac{C A_{i t}}{A_{i t-1}}=\varphi_{0}+\varphi_{1}\left(\frac{1}{A_{i t-1}}\right)+\varphi_{2}\left(\frac{\Delta R E V_{i t}}{A_{i t-1}}-\frac{\Delta R E C_{i t}}{A_{i t-1}}\right)+R O A_{t-1}+\varepsilon_{i t}$ 
$C A$ is current accruals of firm $i$ for year $t$, measured as the total accruals (TA) plus depreciation and amortization expenses. All other variables are defined in the same manner as equation (3).

\section{Real Earnings Management Measure as Dependent Variable}

I employ unexpected abnormal levels of discretionary expenditures (rmUDISX ${ }_{i t}$ ) and abnormal levels of cash flow from operations $\left(\mathrm{rmCASH}_{i t}\right)$ as a proxy for abnormal levels of real earnings management. Following Zang (2012), I first estimate the abnormal level of discretionary expenditures $\left(\operatorname{rmDISX}_{i t}\right)$ as the residuals from the regression (4) below. The regression is estimated cross-sectionally for each year and each two-digit SIC code with at least ten observations, following Roychowdhury (2006):

$\frac{\text { DISX }_{i t}}{A_{i t-1}}=\alpha_{0}+\alpha_{1}\left(\frac{1}{A_{i t-1}}\right)+\alpha_{2}\left(\frac{S_{i t-1}}{A_{i t-1}}\right)+\varepsilon_{i t}$

Where,

$\operatorname{DISX}_{i t}$ : firm $i$ 's discretionary expenditures defined as the sum of $\mathrm{R} \& \mathrm{D}$, advertising, and SG\&A expenditures in year t;

$S_{i t}$ : firm $i$ 's revenue at year $t$;

$A_{i t-1}$ : total asset of firm $i$ for year $\mathrm{t}-1$.

After finding the abnormal level of discretionary expenditures $\left(\operatorname{rmDISX}_{i t}\right)$, I estimate the unexpected abnormal level of discretionary expenditures $\left(\right.$ (mUDISX $\left._{i t}\right)$ as the residuals from the regression of equation (6) below. The regression is estimated crosssectionally for industry-years using two-digit sic codes. 
$\operatorname{rmDISX}_{i t}=\beta_{0}+\beta_{1}$ Market $_{\text {Share }_{i t-1}}+\beta_{2}$ ZSCORE $_{i t-1}+\beta_{3}$ TAX $_{\text {Rate }}+\beta_{4}$ BIG $_{i t}+$ $\beta_{5} N_{O A} A_{i t-1}+\beta_{6} C Y C L E_{i t-1}+\beta_{7} R O A_{i t}+\beta_{8} L o g A T_{i t}+\beta_{9} M t o B_{i t}+\beta_{10} E_{a r n}+\varepsilon_{i t}$

Where,

Market_Share $_{i t-1}$ : the percentage of the company's sales to the total sales of its industry at the beginning of year $t$, where industry is defined based on three-digit SIC code;

$\operatorname{ZSCORE}_{i t-1}: \mathrm{z}$-score at the beginning of the year t. $Z S C O R E_{i t}$ is computed using the following equation, following modified version of Altman's Z-score (Altman 1968, 2000);

$$
\begin{aligned}
& \operatorname{ZSCORE}_{i t}=0.3\left(\frac{N I_{i t}}{\text { Asset }_{i t}}\right)+1.0\left(\frac{\text { Sales }_{i t}}{\text { Asset }_{i t}}\right)+1.4\left(\frac{{\text { Retained } \text { Earning }_{i t}}_{\text {Asset }_{i t}}}{\text { is }}\right) \\
& +1.2\left(\frac{{\text { Working } \text { Capital }_{i t}}_{\text {Asset }_{i t}}}{\text { in }}\right) \\
& +0.6\left(\frac{\text { Stock Price } * \text { Shares Outstanding }}{i t}\right)
\end{aligned}
$$

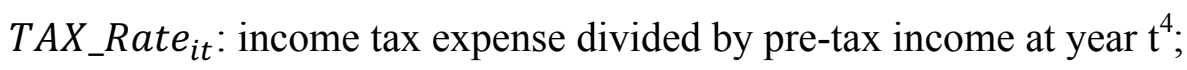

$B I G 8_{i t}$ : indicator variable that equals 1 if the firm's auditor is one of the Big 4 and historically big 8 , and 0 otherwise;

$N O A_{i t-1}$ : indicator variable that equals 1 if the net operating assets, i.e. shareholders' equity less cash and marketable securities and plus total debt, at the

\footnotetext{
${ }^{4}$ In Zang(2012), marginal tax rate developed and provided by Professor John Graham was used, because of the lack of accessibility of the marginal tax rate data, I calculate the tax rate in the above form using Compustat database.
} 
beginning of the year divided by lagged sales is above the median of the corresponding industry-year, and 0 otherwise;

$C Y C L E_{i t-1}$ : days receivable plus the days inventory less the days payable at the beginning of the year, scaled by the number of the days in the year t-1;

$R O A_{i t}$ : return on assets, computed using income before extraordinary items divided by the average of assets in year $t$ and assets in year $t-1$;

$\log _{A} T_{i t}$ : natural logarithm of assets at year $\mathrm{t}$;

$M$ to $B_{i t}$ : market to book ratio;

$\operatorname{Earn}_{i t}$ : earnings before extraordinary items scaled by previous year's assets minus aa ${ }_{i t}$, the measure of discretionary accruals, and subtracting $\operatorname{rmDISX}_{i t}$, the negative value of discretionary expenditures.

To be consistent with Zang (2012), the unexpected abnormal level of discretionary expenditures $\left(\operatorname{rmUDISX}_{i t}\right)$ i.e., the residuals from regression $(\mathrm{b})$, are multiplied by (-1) such that higher values indicate greater amounts of unexpected abnormal levels of discretionary expenditures.

Following Roychowdhury (2006), I estimate normal cash flow from operations as a linear function of sales and change in sales in the current period. To estimate the model, I run the following cross-sectional regression for every industry and year:

$\frac{C F O_{t}}{A T_{t-1}}=\alpha_{0}+\alpha_{1}\left(\frac{1}{A T_{t-1}}\right)+\beta_{t}\left(\frac{S_{t}}{A T_{t-1}}\right)+\beta_{2}\left(\frac{\Delta S_{t}}{A T_{t-1}}\right)+\varepsilon_{t}$

where $A T_{t}$ is the total assetss at the end of period $\mathrm{t}, S_{t}$ the sales during period $\mathrm{t}$ and $\Delta S_{t}=$ $S_{t}-S_{t-1}$. For every firm-year, abnormal cash flow from operations is the actual CFO 
minus the "normal" CFO calculated using estimated coefficients from the corresponding industry-year model and the corresponding industry-year model and the firm-year's sales and lagged assets.

\section{Variables of Interest}

The variable of interest is Miss, a binary variable that equals one if the firm's historical performance or current estimated performance is below that of its peer group. For regressions related to each hypothesis, Miss is calculated differently to match with the related hypothesis. In H1, Miss equals one if firm $i$ 's prior year's performance $\left(R O A_{t-1}\right)$ is below that of its peer group. In $\mathrm{H} 2$, Miss equals one if firm $i$ 's average performance $\left(R O A_{\mu(t-1, t-2)}\right)$ of the past two years is below that of its peer group. $R O A_{\mu(t-1, t-2)}$ is calculated using $\frac{R O A_{t-2}+R O A_{t-1}}{2}$. In H3, Miss equals one if firm $i$ 's expected performance Forecasted_EPS $S_{t}$ at year $t$ is below its peer group's expected performance for year $t$. Firm i's expected performance Forecasted_EPS $S_{t}$ is calculated using analysts' consensus forecasted EPS scaled by scaled by assets per share at the beginning of the fiscal year. Assets per share is calculated using assets divided by common shares used to calculate earnings per share. Consensus analyst forecasted EPS are the mean analysts' forecasts for the next period. If the same analyst revised the previous forecast, I use the most recent revised forecast.

\section{Control Variables}

Following Zang (2012), I include the following variables to control for systematic variation in levels of earnings management related to firm size, growth opportunities, leverage, and current period firm performance. $\operatorname{LogAT} \mathrm{T}_{i t}$ is the natural logarithm of total 
assets of firm $i$ for year $t . \mathrm{BM}_{i t}$ is the book value of equity divided by market value of equity in year $t$ for firm $i$. $\mathrm{ROA}_{i t}$ is return on assets defined as income before extraordinary items in year $t$ divided by the average of total assets. $L E V_{i t}$ is total liabilities divided by total assets in year $t$.

I follow Brown and Caylor (2005) in defining three earnings thresholdsavoiding losses, avoiding earnings declines and avoiding negative earnings surprises. First, firms are considered to avoid losses when income before extraordinary items in year $t$ is equal to or greater than zero. Second, firms are considered to avoid earnings declines when income before extraordinary items in year $t$ is equal to or greater than income before extraordinary items in year $t-1$. Third, firms are considered to avoid negative earnings surprises when actual annual earnings per share are equal to or greater than the annual earnings per share forecast. Threshold 1 is an indicator variable equal to 1 if the firm avoids losses by a small margin, which is defined as income before extraordinary items scaled by the beginning market value within the range of [0.02]. Threshold 2 is an indicator variable equal to 1 if the firm avoids earnings declines by a small margin, which is defined as the change in income before extraordinary items from year $t-1$ to year $\mathrm{t}$, scaled by the beginning market value within the range of [0.01]. Threshold 3 is an indicator variable equal to 1 if the firm avoids negative earnings surprises by a small margin, which is defined as earnings surprises scaled by beginning price per share within the range of [0.0025]

For specific analyses, the control variables vary due to different research designs. For each regression, I also control for industry and year fixed effects. 


\section{Specific Model for Hypotheses Testing}

\section{Model for $\mathrm{H} 1$}

First, I begin with testing whether firms achieving peer performance benchmarks are associated with higher abnormal accruals. To test this conjecture, I modify the base model using an indicator variable for firm-years achieving the peer performance benchmark after controlling for other known earnings benchmarks and other extraneous variables. The empirical model for this test specified as follows:

$D A_{i t}=\alpha_{0}+\alpha_{1}$ Achieve $_{i t}+\alpha_{2} \log _{i t}+\alpha_{3} B M_{i t}+\alpha_{4} L E V_{i t}+\alpha_{5} R O A_{i t}+\alpha_{6} D A_{i t-1}+$ $\alpha_{7}$ Threshold $_{i t}+\alpha_{8}$ Threshold $2_{i t}+\alpha_{9}$ Threshold $_{i t}+\sum_{m} \alpha_{10, m}$ IndDummies $_{m, i t}+$ $\sum_{n} \alpha_{11, n}$ YearDummies $_{n, i t}+\varepsilon_{i t}$

Second, I test whether firms missing the prior year's peer performance benchmarks are associated with a higher level of abnormal accruals in the current year. To test this conjecture, I modify the base model using an indicator variable for firm-years missing the prior year's peer performance benchmark after controlling for other known earnings benchmarks and other extraneous variables. The empirical model for this test specified as follows:

$$
\begin{aligned}
& D A_{i t}=\alpha_{0}+\alpha_{1} \text { Miss }_{i t-1}+\alpha_{2} \text { LogAT }_{i t}+\alpha_{3} B M_{i t}+\alpha_{4} \text { LEV }_{i t}+\alpha_{5} \text { ROA }_{i t}+\alpha_{6} \text { DA }_{i t-1}+ \\
& \alpha_{7} \text { Threshold }_{i t}+\alpha_{8} \text { Threshold }_{i t}+\alpha_{9} \text { Threshold }_{i t}+\sum_{m} \alpha_{10, m} \text { IndDummies }_{m, i t}+ \\
& \sum_{n} \alpha_{11, n} \text { YearDummies }_{n, i t}+\varepsilon_{i t}
\end{aligned}
$$


Third, I test the joint effect of achieving the current year's peer performance benchmark and missing the prior year's peer performance benchmark on accruals management. To test this conjecture, I modify the base model using an interaction term of firms achieving the current year's peer performance benchmark and firms underperforming compared to the prior year's peer performance after controlling for other known earnings benchmarks and other extraneous variables. The empirical model for this test specified as follows:

$$
\begin{aligned}
& \mathrm{DA}_{i t}=\alpha_{0}+\alpha_{1} \text { Achieve }_{i t}+\alpha_{2} \text { UnPerf }_{i t-1}+\alpha_{3} \text { Achieve }_{i t} * \text { UnPerf }_{i t-1}+ \\
& \alpha_{4} \text { LogAT }_{i t}+\alpha_{5} \text { BM }_{i t}+\alpha_{6} \text { DA }_{i t-1}+\alpha_{7} \text { LEV }_{i t}+\alpha_{8} \text { ROA }_{i t}+\alpha_{9} \text { Threshold }_{i t}+ \\
& \alpha_{10} \text { Threshold }_{i t}+\alpha_{11} \text { Threshold }_{i t}++\sum_{m} \alpha_{12, m} \text { IndDummies }_{m, i t}+ \\
& \sum_{n} \alpha_{13, n} \text { YearDummies }_{n, i t}+\varepsilon_{i t}
\end{aligned}
$$

Fourth, I test whether firms achieving peer performance benchmarks are associated with higher levels of real activities manipulation. To test this conjecture, I modify the base model using an indicator variable for firm-years achieving the peer performance benchmark after controlling for other known earnings benchmarks and other extraneous variables. The empirical model for this test specified as follows:

$$
\begin{aligned}
& R M_{i t}=\alpha_{0}+\alpha_{1} \text { Achieve }_{i t}+\alpha_{2} \operatorname{LogAT}_{i t}+\alpha_{3} \mathrm{BM}_{i t}+\alpha_{4} L E V_{i t}+\alpha_{5} \mathrm{ROA}_{i t}+
\end{aligned}
$$

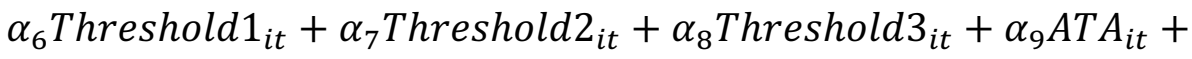

$$
\begin{aligned}
& \sum_{m} \alpha_{10, m} \text { IndDummies }_{m, i t}+\sum_{n} \alpha_{11, n} \text { YearDummies }_{n, i t}+\varepsilon_{i t}
\end{aligned}
$$


Fifth, I test whether firms missing the prior year's peer performance benchmarks are associated with higher levels of real activities manipulation in the current year. To test this conjecture, I modify the base model using an indicator variable for firm-years missing the prior year's peer performance benchmark after controlling for other known earnings benchmarks and other extraneous variables. The empirical model for this test specified as follows:

$R M_{i t}=\alpha_{0}+\alpha_{1}$ Miss $_{i t-1}+\alpha_{2} \operatorname{LogAT}_{i t}+\alpha_{3} \mathrm{BM}_{i t}+\alpha_{4} L E V_{i t}+\alpha_{5} \mathrm{ROA}_{i t}+$

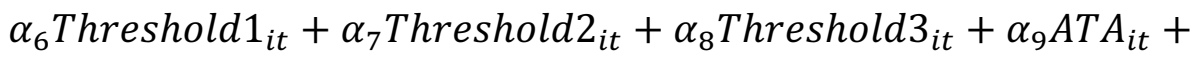
$\sum_{m} \alpha_{10, m}$ IndDummies $_{m, i t}+\sum_{n} \alpha_{11, n}$ YearDummies $_{n, i t}+\varepsilon_{i t}$

Sixth, I test the joint effect of achieving the current year's peer performance benchmark and underperforming compared to the prior year's peer performance on the real activities manipulation. To test this conjecture, I modify the base model using an interaction term for achieving the current year's peer performance benchmark and underperforming compared to prior year's peer performance after controlling for other known earnings benchmarks and other extraneous variables. The empirical model for this test specified as follows:

$$
\begin{aligned}
& \mathrm{RM}_{i t}=\alpha_{0}+\alpha_{1} \text { Achieve }_{i t}+\alpha_{2} \operatorname{UnPerf}_{i t-1}+\alpha_{3} \text { Achieve }_{i t} * \operatorname{UnPerf}_{i t-1}+ \\
& \alpha_{4} \log A T_{i t}+\alpha_{5} B M_{i t}+\alpha_{6} L E V_{i t}+\alpha_{7} R O A_{i t}+\alpha_{8} \text { Threshold } 1_{i t}+\alpha_{9} \text { Threshold } 2_{i t}+ \\
& \alpha_{10} \text { Threshold }_{i t}+\alpha_{11} \text { ATA }_{i t}+\sum_{m} \alpha_{12, m} \text { IndDummies }_{m, i t}+ \\
& \sum_{n} \alpha_{13, n} \text { YearDummies }_{n, i t}+\varepsilon_{i t}
\end{aligned}
$$


All the variables have been explained above. The control variables are different between the regressions of discretionary accruals and real earnings management. In the models (7), (8), (9), I controlled for prior year's discretionary accruals because Allen et al. (2013) document pervasive evidence of reversals in firm-level accruals over adjacent fiscal years. In the models (10), (11), (12), I control for the current year's total accruals because Zang (2012) finds that managers trade off the two earnings management methods based on their relative costs.

\section{Model for $\mathrm{H} 2$}

First, I test whether firms missing the prior two year's mean peer performance benchmarks are associated with a higher level of abnormal accruals in the current year. To test this conjecture, I modify the base model using an indicator variable for firm-years missing the prior two year's mean peer performance benchmark after controlling for other known earnings benchmarks and other extraneous variables. The empirical model for this test specified as follows:

$$
\begin{aligned}
& D A_{i t}=\alpha_{0}+\alpha_{1} \text { Miss }_{i \mu(t-1, t-2)}+\alpha_{2} \operatorname{LogAT}_{i t}+\alpha_{3} \mathrm{BM}_{i t}+\alpha_{4} L_{E V_{i t}}+\alpha_{5} \mathrm{ROA}_{i t}+
\end{aligned}
$$

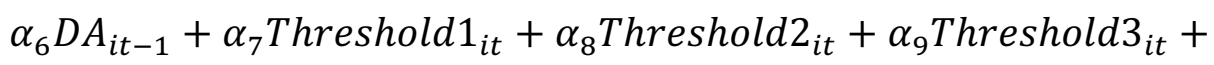

$$
\begin{aligned}
& \sum_{m} \alpha_{10, m} \text { IndDummies }_{m, i t}+\sum_{n} \alpha_{11, n} \text { YearDummies }_{n, i t}+\varepsilon_{i t}
\end{aligned}
$$

Second, I test the joint effect of achieving the current year's peer performance benchmark and missing the prior two year's mean peer performance benchmark on accruals management. To test this conjecture, I modify the base model using an interaction term for achieving the current year's peer performance benchmark and 
underperforming compared to the prior two year's mean peer performance after controlling for other known earnings benchmarks and other extraneous variables. The empirical model for this test specified as follows:

$$
\begin{aligned}
& D A_{i t}=\alpha_{0}+\alpha_{1} \text { Achieve }_{i t}+\alpha_{2} \text { UnPerf }_{i \mu(t-1, t-2)}+\alpha_{3} \text { Achieve }_{i t} * \text { UnPerf }_{i \mu(t-1, t-2)}+ \\
& \alpha_{4} \operatorname{LogAT}_{i t}+\alpha_{5} \mathrm{BM}_{i t}+\alpha_{6} \text { LEV }_{i t}+\alpha_{7} \mathrm{ROA}_{i t}+\alpha_{8} \text { DA }_{i t-1}+\alpha_{9} \text { Threshold }_{i t}+ \\
& \alpha_{10} \text { Threshold }_{i t}+\alpha_{11} \text { Threshold }_{i t}+\sum_{m} \alpha_{12, m} \text { IndDummies }_{m, i t}+ \\
& \sum_{n} \alpha_{13, n} \text { YearDummies }_{n, i t}+\varepsilon_{i t}
\end{aligned}
$$

Third, I test whether firms missing the prior two year's mean peer performance benchmarks are associated with higher levels of real activities manipulation in the current year. To test this conjecture, I modify the base model using an indicator variable for firmyears missing the prior two year's mean peer performance benchmark after controlling for other known earnings benchmarks and other extraneous variables. The empirical model for this test specified as follows:

$$
\begin{aligned}
& \mathrm{RM}_{i t}=\alpha_{0}+\alpha_{1} \text { Miss }_{i \mu(t-1, t-2)}+\alpha_{2} \operatorname{LogAT}_{i t}+\alpha_{3} \mathrm{BM}_{i t}+\alpha_{4} \text { LEV }_{i t}+\alpha_{5} \mathrm{ROA}_{i t}+ \\
& \alpha_{6} \text { Threshold }_{i t}+\alpha_{7} \text { Threshold }_{i t}+\alpha_{8} \text { Threshold }_{i t}+\alpha_{9} \text { ATA }_{i t}+ \\
& \sum_{m} \alpha_{10, m} \text { IndDummies }_{m, i t}+\sum_{n} \alpha_{11, n} \text { YearDummies }_{n, i t}+\varepsilon_{i t}
\end{aligned}
$$

Fourth, I test the joint effect of achieving the current year's peer performance benchmark and missing the prior two year's mean peer performance benchmark on real activities manipulation. To test this conjecture, I modify the base model using an 
interaction term for achieving the current year's peer performance benchmark and missing the prior two year's mean peer performance benchmark after controlling for other known earnings benchmarks and other extraneous variables. The empirical model for this test specified as follows:

$$
\begin{aligned}
& \mathrm{RM}_{i t}=\alpha_{0}+\alpha_{1} \text { Achieve }_{i t}+\alpha_{2} \text { UnPerf }_{i \mu(t-1, t-2)}+\alpha_{3} \text { Achieve }_{i t} * \text { UnPerf }_{i \mu(t-1, t-2)}+ \\
& \alpha_{4} \text { LogAT }_{i t}+\alpha_{5} \mathrm{BM}_{i t}+\alpha_{6} \text { LEV }_{i t}+\alpha_{7} \mathrm{ROA}_{i t}+\alpha_{8} \text { Threshold }_{i t}+\alpha_{9} \text { Threshold }_{i t}+ \\
& \alpha_{10} \text { Threshold }_{i t}+\alpha_{11} \text { ATA }_{i t}+\sum_{m} \alpha_{12, m} \text { IndDummies }_{m, i t}+ \\
& \sum_{n} \alpha_{13, n} \text { YearDummies }_{n, i t}+\varepsilon_{i t}
\end{aligned}
$$

All the variables have been explained above.

\section{Model for $\mathrm{H3}$}

First, I test whether firms missing the expected peer performance benchmarks are associated with a higher level of abnormal accruals in the current year. To test this conjecture, I modify the base model using an indicator variable for firm-years missing the current year's expected peer performance benchmarks after controlling for other known earnings benchmarks and other extraneous variables. The empirical model for this test specified as follows:

$$
\begin{aligned}
& D A_{i t}=\alpha_{0}+\alpha_{1} \text { EMiss }_{i t}+\alpha_{2} \operatorname{LogAT}_{i t}+\alpha_{3} \mathrm{BM}_{i t}+\alpha_{4} \text { LEV }_{i t}+\alpha_{5} \mathrm{ROA}_{i t}+\alpha_{6} \text { DA }_{i t-1}+ \\
& \alpha_{7} \text { Threshold }_{i t}+\alpha_{8} \text { Threshold }_{i t}+\alpha_{9} \text { Threshold }_{i t}+\sum_{m} \alpha_{10, m} \text { IndDummies }_{m, i t}+ \\
& \sum_{n} \alpha_{11, n} \text { YearDummies }_{n, i t}+\varepsilon_{i t}
\end{aligned}
$$


Second, I test the joint effect of achieving the current year's peer performance benchmark and missing the current year's expected peer performance benchmark on accruals management. To test this conjecture, I modify the base model using an interaction term for achieving the current year's peer performance benchmark and underperforming the current year's expected peer performance after controlling for other known earnings benchmarks and other extraneous variables. The empirical model for this test specified as follows:

$D A_{i t}=\alpha_{0}+\alpha_{1}$ Achieve $_{i t}+\alpha_{2}$ EUnPerf $_{i t}+\alpha_{3}$ Achieve $_{i t} *$ EUnPerf $_{i t}+\alpha_{4}$ LogAT $_{i t}+$ $\alpha_{5} \mathrm{BM}_{i t}+\alpha_{6} L E V_{i t}+\alpha_{7} \mathrm{ROA}_{i t}+\alpha_{8} D A_{i t-1}+\alpha_{9}$ Threshold $1_{i t}+\alpha_{10}$ Threshold $2_{i t}+$ $\alpha_{11}$ Threshold $_{i t}+\sum_{m} \alpha_{12, m}$ IndDummies $_{m, i t}+\sum_{n} \alpha_{13, n}$ YearDummies $_{n, i t}+\varepsilon_{i t}$

Third, I test whether firms missing the expected peer performance benchmarks are associated with a higher level of real activities manipulation in the current year. To test this conjecture, I modify the base model using an indicator variable for firm-years missing the current year's expected peer performance benchmarks after controlling for other known earnings benchmarks and other extraneous variables. The empirical model for this test specified as follows:

$$
\begin{aligned}
& R M_{i t}=\alpha_{0}+\alpha_{1} \text { MMiss }_{i t}+\alpha_{2} \operatorname{LogAT}_{i t}+\alpha_{3} \mathrm{BM}_{i t}+\alpha_{4} L E V_{i t}+\alpha_{5} \mathrm{ROA}_{i t}+
\end{aligned}
$$

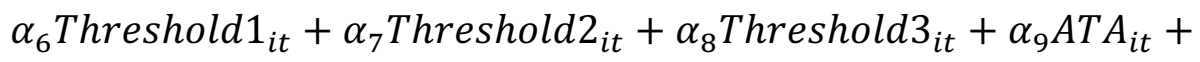

$$
\begin{aligned}
& \sum_{m} \alpha_{10, m} \text { IndDummies }_{m, i t}+\sum_{n} \alpha_{11, n} \text { YearDummies }_{n, i t}+\varepsilon_{i t}
\end{aligned}
$$


Fourth, I test the joint effect of achieving the current year's peer performance benchmark and missing the current year's expected peer performance benchmark on real activities manipulation. To test this conjecture, I modify the base model using an interaction term for achieving the current year's peer performance benchmark and underperforming the current year's expected peer performance after controlling for other known earnings benchmarks and other extraneous variables. The empirical model for this test specified as follows:

$$
\begin{aligned}
& \operatorname{rmUDISX}_{i t}=\alpha_{0}+\alpha_{1} \text { Achieve }_{i t}+\alpha_{2} \text { EUnPerf }_{i t}+\alpha_{3} \text { Achieve }_{i t} * \text { EUnPerf }_{i t}+ \\
& \alpha_{4} \text { LogAT }_{i t}+\alpha_{5} \mathrm{BM}_{i t}+\alpha_{6} \text { LEV }_{i t}+\alpha_{7} \mathrm{ROA}_{i t}+\alpha_{8} \text { Threshold }_{i t}+\alpha_{9} \text { Threshold }_{i t}+ \\
& \alpha_{10} \text { Threshold }_{i t}+\alpha_{11} \text { ATA }_{i t}+\sum_{m} \alpha_{12, m} \text { IndDummies }_{m, i t}+ \\
& \sum_{n} \alpha_{13, n} \text { YearDummies }_{n, i t}+\varepsilon_{i t}
\end{aligned}
$$

All the variables have been explained above.

\section{Model for H4:}

First, I test whether firms missing the first three quarter's cumulative peer performance benchmarks are associated with a higher level of abnormal accruals in the fourth quarter. I modify the base model using an indicator variable for firm-years missing the first three quarter's cumulative peer performance benchmark.

$$
\begin{aligned}
& D A_{i t(q 4)}=\alpha_{0}+\alpha_{1} \operatorname{MiSS}_{i t \sum(q 1, q 2, q 3)}+\alpha_{2} \operatorname{LogAT}_{i t(q 4)}+\alpha_{3} \mathrm{BM}_{i t(q 4)}+\alpha_{4} L E V_{i t(q 4)}+
\end{aligned}
$$

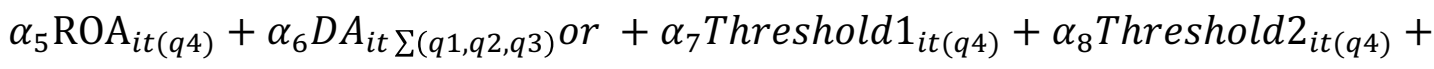

$$
\begin{aligned}
& \alpha_{9} \text { Threshold } 3_{i t(q 4)}+\text { IndDummies }+ \text { YearDummies }+\varepsilon_{i t}
\end{aligned}
$$


Second, I test the joint effect of achieving the current year's peer performance benchmark and missing the first three quarter's cumulative peer performance benchmark on accruals management for the fourth quarter. To test this conjecture, I modify the base model using an interaction term for achieving the current year's peer performance benchmark and underperforming the first three quarter's cumulative peer performance after controlling for other known earnings benchmarks and other extraneous variables. The empirical model for this test specified as follows:

$$
\begin{aligned}
& D A_{i t(q 4)}=\alpha_{0}+\alpha_{1} \text { Achieve }_{i t}+\alpha_{2} \operatorname{UnPerf}_{i t \sum(q 1, q 2, q 3)}+\alpha_{3} \text { Achieve }_{i t} * \\
& \operatorname{UnPerf}_{i t \sum(q 1, q 2, q 3)}+\alpha_{4} \log _{\mathrm{AT}_{i t(q 4)}}+\alpha_{5} \mathrm{BM}_{i t(q 4)}+\alpha_{6} L E V_{i t(q 4)}+\alpha_{7} \mathrm{ROA}_{i t(q 4)}+ \\
& \alpha_{8} D A_{i t \sum(q 1, q 2, q 3)}+\alpha_{9} \text { Threshold } 1_{i t(q 4)}+\alpha_{10} \text { Threshold } 2_{i t(q 4)}+ \\
& \alpha_{11} \text { Threshold }_{i t(q 4)}+\sum_{m} \alpha_{12, m} \text { IndDummies }_{m, i t(q 4)}+ \\
& \sum_{n} \alpha_{13, n} \text { YearDummies }_{n, i t(q 4)}+\varepsilon_{i t}
\end{aligned}
$$

Third, I test whether firms missing the first three quarter's cumulative peer performance benchmarks are associated with a higher level of abnormal accruals in the fourth quarter. To test this conjecture, I modify the base model using an indicator variable for firm-years missing the first three quarter's cumulative peer performance benchmark.

$$
\begin{aligned}
& \mathrm{RM}_{i t(q 4)}=\alpha_{0}+\alpha_{1} \operatorname{Miss}_{i t \sum(q 1, q 2, q 3)}+\alpha_{2} \operatorname{LogAT}_{i t(q 4)}+\alpha_{3} \mathrm{BM}_{i t(q 4)}+\alpha_{4} L E V_{i t(q 4)}+
\end{aligned}
$$

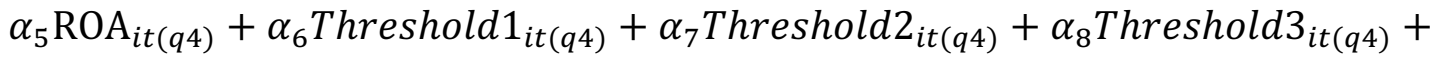

$$
\begin{aligned}
& \alpha_{9} A T A_{i t(q 4)}+\sum_{m} \alpha_{10, m} \text { IndDummies }_{m, i t(q 4)}+\sum_{n} \alpha_{11, n} \text { YearDummies }_{n, i t(q 4)}+\varepsilon_{i t}
\end{aligned}
$$


Fourth, I test the joint effect of achieving the current year's peer performance benchmark and missing the first three quarter's cumulative peer performance benchmark on real earnings manipulation of the fourth quarter. To test this conjecture, I modify the base model using an interaction term for achieving the current year's peer performance benchmark and underperforming the first three quarter's cumulative peer performance after controlling for other known earnings benchmarks and other extraneous variables. The empirical model for this test specified as follows:

$$
\begin{aligned}
& \operatorname{rmUDISX}_{i t(q 4)}=\alpha_{0}+\alpha_{1} \text { Achieve }_{i t}+\alpha_{2} \operatorname{UnPerf}_{i t \sum(q 1, q 2, q 3)}+\alpha_{3} \text { Achieve }_{i t} * \\
& \operatorname{UnPerf}_{i t \Sigma(q 1, q 2, q 3)}+\alpha_{4} \operatorname{LogAT}_{i t(q 4)}+\alpha_{5} \mathrm{BM}_{i t(q 4)}+\alpha_{6} L E V_{i t(q 4)}+\alpha_{7} \mathrm{ROA}_{i t(q 4)}+
\end{aligned}
$$

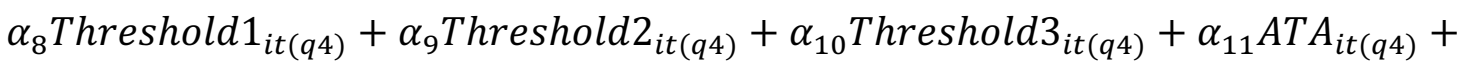

$$
\begin{aligned}
& \sum_{m} \alpha_{12, m} \text { IndDummies }_{m, i t(q 4)}+\sum_{n} \alpha_{13, n} \text { YearDummies }_{n, i t(q 4)}+\varepsilon_{i t}
\end{aligned}
$$

Where,

Achieve $_{i t}$ is a dummy variable and it equals one if firm $i$ 's current year's performance $\left(R O A_{t}\right)$ is above the peer group by a certain range. $\operatorname{UnPerf}_{i t \Sigma(q 1, q 2, q 3)}$ : equals one if firm i's cumulative performance $\left(R O A_{\sum(q 1, q 2, q 3)}\right)$ of the first three quarters in year $\mathrm{t}$ is below that of its peer group by a certain range.

$R O A_{\sum(q 1, q 2, q 3)}$ is calculated using income before extraordinary items in quarter 1, add that in quarter 2 , quarter 3 , then use the cumulative number divided by average of assets at the beginning of quarter 1 and the end of quarter 3; 
$D A_{i t(q 4)}$ : firm $i$ 's discretionary accrual at the fourth quarter in year $t$. There are two measures for discretionary accrual: $A T A_{i t(q 4)}$, which is the abnormal total accrual at the fourth quarter in year $\mathrm{t}$, and $A C A_{i t(q 4)}$, which is the abnormal working capital accrual at the fourth quarter in year t. They are calculated using equation (3) and equation (4), respectively. $\mathrm{RM}_{i t(q 4)}$ : firm i's level of real earnings management at the fouth quarter in year $\mathrm{t}$. There are two measures for real earnings management: $\operatorname{rmUDISX}_{i t(q 4)}$, which is the unexpected abnormal level of discretionary expenditures at the fourth quarter in year t. $\operatorname{rmCash}_{i t(q 4)}$, which is the abnormal cash flow from operations at the fourth quarter in year $\mathrm{t}$.

$\operatorname{LogAT}_{i t(q 4)}$ : natural logarithm of asset at fourth quarter of firm $i$ for year $t$; $\mathrm{BM}_{i t(q 4)}$ : book value of equity divided by market value of equity at fourth quarter of year $t$ for firm $i$;

$L E V_{i t(q 4)}$ : total liability divided by total assets at fourth quarter of year $t$ $\mathrm{ROA}_{i t(q 4)}$ : income before extraordinary items at fourth quarter of year in year $t$ divided; by the average of total assets of the fourth quarter and beginning of fourth quarter in year $t$;

$D A_{i t \sum(q 1, q 2, q 3)}$ : firm $i$ 's discretionary accrual at the first three quarters of year $t$. There are two measures for discretionary accrual: $A T A_{i t} \sum(q 1, q 2, q 3)$, which is the abnormal total accrual of the first three quarters at year $\mathrm{t}$, and $A C A_{i t} \sum(q 1, q 2, q 3)$, 
which is abnormal working capital accrual of the first three quarters at year $t$.

They are calculated using equation (3) and equation (4), respectively.

Threshold $1_{i t(q 4)}$, Threshold $2_{i t(q 4)}$ and Threshold $3_{i t(q 4)}$ : equals one if firm i

just meet and beat threshold 1, threshold 2 or threshold 3 in the fourth quarter of year $t$. respectively. The definition of just meet and beat each threshold is explained in the previous section.

\section{Model for $\mathrm{H5}$}

In this section, I use the logistic models to test whether achieving or missing the peer performance benchmark has an impact on the probability of misreporting. First, I test the joint effect of firms achieving current year's peer performance benchmark and abnormal accruals. To test this conjecture, I use the interaction term for achieving the current year's peer performance benchmark and the current year's abnormal accruals and control for other known earnings benchmarks and other extraneous variables. The empirical model for this test specified as follows:

$\operatorname{Pr}\left(\right.$ RESTATEMENT_PERIOD $\left._{i t}=1\right)=F\left(\alpha_{0}+\alpha_{1}\right.$ Achieve $_{i t}+\alpha_{1} D A_{i t}+$ Achieve $_{i t} *$ $D A_{i t}+$ Control Variables + IndDummies + YearDummies $\left.+\varepsilon_{i t}\right)$

Second, I test the joint effect of firms achieving the current and missing the prior peer performance benchmarks, and abnormal accruals. To test this conjecture, I use the interaction term of the dummy variable indicating achieving current and missing prior peer performance benchmark, and the continuous variable, current year's abnormal 
accruals, and control for other known earnings benchmarks and other extraneous variables. The empirical model for this test specified as follows:

$\operatorname{Pr}($ RESTATEMENT_PERIOD $i t=1)=F\left(\alpha_{0}+\alpha_{1}\right.$ Achieve_Miss $+\alpha_{2} D A_{i t}+$ $\alpha_{3}$ Achieve_Miss $* D A_{i t}+$ Control Variables + IndDummies + YearDummies + $\left.\varepsilon_{i t}\right)$

Third, I test whether missing the prior peer performance benchmarks increases the probability of misreporting. To test this conjecture, I use the dummy variable for firms missing the prior peer performance benchmarks and control for other known earnings benchmarks and other extraneous variables. The empirical model for this test specified as follows:

$\operatorname{Pr}($ RESTATEMENT_PERIOD $i t=1)=F\left(\alpha_{0}+\alpha_{1}\right.$ Miss + Control Variables + IndDummies + YearDummies $\left.+\varepsilon_{i t}\right)$

Restatement_Period $_{i t}$ is an indicator variable equal to one if firm $i$ is among the misstatement years. For example, let's say firm $i$ managed earnings in 2002 and 2003. Firm $i$ is included for firm-year 2002 and 2003 (coded as Restatement_Period $i t=1$ ). On Audit Analytics where restatement data is provided, the earliest restatement announcement is in year 2000. So the data when I use this regression model starts from year 2002 . 


\section{V.SAMPLE SELECTION AND DATA COLLECTION}

This study uses four samples. My first sample is obtained from the Compustat fundamental annual file and $\mathrm{I} / \mathrm{B} / \mathrm{E} / \mathrm{S}$ detail file for the period 1988 through 2012 . Although my sample period begins in 1988, as I require three years of financial information in calculating the previous two years' ROA, my empirical tests are thus based on the sample period 1991 through 2012. Following prior studies, I delete all financial institutions (SIC codes: 6000-6999) and utilities (SIC codes: 4400-5000). Because certain variables are scaled by previous year's total assets, firm years with total assets less than $\$ 1$ million in fiscal year $t-1$ are deleted. As I estimate abnormal total accruals $(A T A)$, abnormal current accruals $(A C A)$, the unexpected abnormal level of discretionary expenditures $\left(\right.$ rmUDISX $\left._{i t}\right)$ and the abnormal cash flow from operations $\left(\mathrm{rmCASH}_{i t}\right)$ for each year-industry combination, I delete the industries (i.e., two-digit SIC code) with less than ten firm years in a given fiscal year. All variables except for the indicator variables are winsorized at the $1 \%$ and $99 \%$ levels.

The second sample is obtained from the Compustat fundamental quarterly file and $\mathrm{I} / \mathrm{B} / \mathrm{E} / \mathrm{S}$ detail file for 1988 through 2012. I require five quarters of information in estimating certain variables such as abnormal accruals of the previous three quarters, thus my empirical tests are based on a sample period of 1990 through 2012. Following prior studies, I delete all firms in the financial services (SIC codes: 6000-6999) and utilities (SIC codes: 4400-5000) industries. As I estimate abnormal total accruals (ATA), abnormal current accruals $(A C A)$, the unexpected abnormal level of discretionary expenditures $\left(\mathrm{rmCASH}_{i t}\right)$ and the abnormal cash flow $\left(\mathrm{rmCASH}_{i t}\right)$ for each fourth 
quarter-industry combination, I delete the industries (i.e., two-digit SIC code) with less than ten firm-years in a given fourth quarter. Since the model is built to observe fourth quarter earnings management, the final sample contains only fourth quarter data for each year.

The third sample is obtained from Compustat fundamental annual file, $\mathrm{I} / \mathrm{B} / \mathrm{E} / \mathrm{S}$ detail file and the Audit Analytics file for 2000 through 2012. The sample derivation follows the same steps as the first sample. Then I merge those observations with the Audit Analytics file, and I delete the fiscal year before 2000 because the earliest restatement announcement is in year 2000 .

The fourth sample is obtained from the Compustat fundamental quarterly file, I/B/E/S detailed file and the Audit Analytics file for 2000 through 2012. The sample derivation follows the same steps as the second sample. Then I merge those observations with the Audit Analytics file, I delete the fiscal year before 2000 because the earliest restatement announcement is in year 2000.

Table 1 provides the sample derivation for empirical analyses of discretionary accruals measures - abnormal total accruals $(A A)$ and abnormal current accruals $(A W C A)$, real earnings management measures - the abnormal level of discretionary expenditures $(\mathrm{rmUDISX})$ and the abnormal cash flow from operations $(\mathrm{rmCASH})$, and restatement (RESTATEMENT_PERIOD). The Compustat annual file has 116,635 firm-year observation from 1988-2012. After the steps described above, there are 47,968 firm-year observations with discretionary accrual measures and 46,930 firm-year observations with real earnings management measures. After I merge them with restatement data, I delete 
the firm-year before fiscal year 2000 and 29,604 firm-year observations are used for analyses with restatement. The Compustat quarterly file has 167,982 firm-quarter observation from 1988-2012. After the steps described above, there are 29,589 firmfourth-quarter observations with discretionary accruals measures and 25,779 firm-fourthquarter with real earnings management measures. After I merge them with restatement data, I delete the observations before fiscal year 2000 and 146,82 firm-quarter observations are used for analyses with restatement.

\section{VI.EMPIRICAL FINDINGS}

\section{Descriptive Statistics}

Table 2 provides the descriptive statistics of the firms missing the historical and current peer performance benchmarks, the abnormal total accruals, abnormal current accruals, the unexpected abnormal level of discretionary expenditures, abnormal cash flows from operations, and the control variables. The mean and median are consistent with previous research (Roychowdury 2006; Zang 2012). The mean value of abnormal total accruals is -0.0176 . The mean value of abnormal current accruals is -0.0132 . The mean value of the abnormal level of discretionary expenditures is 0.0028 . The value of abnormal cash flows from operations is 0.0263 . 


\section{Correlation}

Table 3 provides the correlations among various variables. Upper diagonal cells are Pearson correlations and lower diagonal cells are Spearman correlations. There are high negative correlations among the accruals management measures-abnormal total accruals, abnormal current accruals, and real earnings management measuresunexpected abnormal level of discretionary expenditures, abnormal cash flow from operations. There could be two explanations. One is the correlation is mechanical because one variable is used in the calculations of the other variables. For example, abnormal total accruals are used in the calculation of unexpected abnormal level of discretionary expenditures. The other reason is the trade-off between real activities manipulation and accrual-based earnings management (Zang 2012).

\section{Multiple Regression Analyses}

This section provides the empirical results of firms missing the historical and current peer performance benchmarks.

\section{Missing Prior Year's Peer Performance Benchmark}

Tables 4 through 9 provide evidence supporting H1. First, I estimate equation (7-9) by using two proxies for accrual management as dependent variables: (a) abnormal total accruals, (b) abnormal current accruals. Second, I estimate equation (9-12) by using two proxies for real earnings manipulation as dependent variables: (a) unexpected abnormal level of discretionary expenditures, (b) abnormal cash flow from operations. 


\section{Accruals Management Tests}

Table 4 provides the regression results of equation (7). For both measures, the coefficients on the variable of interest Achieve $_{i t}$ is positive and significant, suggesting that those firm with return on assets (ROA) just above their peer group (achieve within the range of 0.05 ) in the current year exhibit greater income-increasing abnormal accruals. Firms just achieved current year's peer performance benchmark have higher abnormal accruals compared to the rest of the sample provide evidence that firms use discretionary accruals to boost earnings to achieve the peer performance benchmark.

Table 5 provides the regression results of equation (8). For both measures, the coefficients on the variable of interest $M i s s_{i t-1}$ is positive and significant, suggesting that firms with prior year performance that is below that of their peer group will exhibit greater levels of income-increasing accruals management in current year earnings. When the dependent variable is abnormal total accruals, the coefficient on Miss $_{i t-1}$ is positive $(0.0442)$ and significant at the $1 \%$ level $(\mathrm{p}<0.0001)$. Those firm years have abnormal total accruals that are higher on average by $4.42 \%$ of assets compared to the rest of the sample. When the dependent variable is abnormal current accruals, the coefficient on Miss $_{i t-1}$ is positive $(0.0386)$ and significant at the $1 \%$ level $(\mathrm{p}<0.0001)$. Those firm years have abnormal current accruals that are higher on average by $3.86 \%$ of assets compared to the rest of the sample.

The coefficients for the control variables are consistent with prior studies. The coefficient on $L E V$ is positive and significant, indicating that firms with higher leverage are more likely to have higher abnormal accruals. The coefficient on SIZE is negative and 
significant since larger firms tend to have lower abnormal accruals. The coefficient on $B M$ is positive and significant. For the long-term earnings growth, although $\mathrm{McNichols}$ (2000) conjectured that firms with greater expected earnings growth are likely to have greater accruals than firms with less expected earnings growth, I observe the opposite sign. One explanation is that the relation between expected earnings growth and abnormal accruals is not linear. (Collins 2012). The coefficient on ROA is positive and significant. Although I control for the level of firm performance when calculating the accruals management measures, this discretionary accruals model is still misspecificed when applied to samples of firms with extreme performance in part because performance (Kothari et al. 2005). One thing worth noticing is the positive and significant correlation between the prior year's abnormal accrual and the current year's abnormal accruals. Although accruals reverse at the individual transaction level, they need not reverse at the firm level since the new originating accruals can offset old reversing accruals. Allen et al. (2013) finds the reversals in firm-level accruals over adjacent fiscal years. Accruals related to firm growth are positively serially correlated. Accruals related to temporary fluctuations in working capital, such as a firm may temporarily accelerate normal inventory purchases, is negatively serially correlated. Thus, one explanation for the negative correlation in my test is that discretionary accruals measurements are not clean measurements that rule out that accruals are related to firm growth.

Table 6 provides the regression results of equation (9). The interaction term Achieve $_{i t} * \operatorname{UnPerf}_{i t-1}$, captures the incremental effect on accruals management of firms both just achieving ( achieve within the range of 0.05) current year's peer performance benchmark and just missing (miss within the range of -0.05) last year's peer 
performance benchmark, is positive and significant, indicating those firms are more likely to manage accruals in the current year.

\section{Real Activities Manipulation Tests}

Table 7 provides the regression results of equation (10). The coefficient on Achieve $_{i t}$ is not significant when $r m U D I S X_{i t}$ is the dependent variable, yet the coefficient is significant when $r m U D I S X_{i t}$ is the proxy for real activities manipulation. My expectation that firms just achieve their peer performance benchmark would have higher level of real earnings management in the current year is not supported.

Table 8 provides the regression results of equation (11). For both measures, the coefficients on the variable of interest Miss $_{i t-1}$ is positive and significant, suggesting that firms with prior year performance that is below that of their peer group will exhibit greater levels of income-increasing real activities manipulation in current year earnings. When the dependent variable is unexpected abnormal level of discretionary expenditures, the coefficient on Miss $_{i t-1}$ is positive (0.0062) and significant at the $1 \%$ level $(p<0.0001)$. Those firm years have unexpected abnormal level of discretionary expenditures that are higher on average by $0.62 \%$ of assets compared to the rest of the sample. When the dependent variable is abnormal cash flow from operations, the coefficient on Miss $_{i t-1}$ is positive (0.0136) and significant at the $1 \%$ level $(\mathrm{p}<0.0001)$. Those firm years have abnormal cash flow from operations that are higher on average by $1.36 \%$ of assets compared to the rest of the sample.

Table 9 provides the regression results of equation (12). The coefficient on Achieve $_{i t} * \operatorname{UnPerf}_{i t-1}$ is positive and significant regressed on abnormal cash flows, 
indicating firms just achieved ( achieve within the range of 0.05) current year's peer performance benchmark and just missed ( miss within the range of -0.05) last year's peer performance benchmark have higher abnormal cash flows compared to the rest of the sample provide evidence that firms use real activities to increase cash to boost earnings to achieve the peer performance benchmark. However, when the dependent variable is rmUDIS $X_{i t}$, the coefficient on the interaction term is not significant. So the results presented in Table 9 are less convincing.

\section{Missing Prior Two Year's Mean Peer Performance Benchmark}

Tables 10 through 13 provide evidence consistent with H2. First, I estimate equations (13) and (14) using two proxies for accruals management as dependent variables-(a) abnormal total accruals, (b) abnormal working capital accruals. Second, I estimate equations (15) and (16) by using two proxies for real activities manipulation as dependent variables - (a) unexpected abnormal level of discretionary expenditures, (b) abnormal cash flow from operations.

\section{Accruals Management Tests}

Table 10 provides the regression results of equation (13). For both measures, the coefficients on the variable of interest $\operatorname{Miss}_{i \mu(t-1, t-2)}$ is positive and significant, suggesting that if a firm's average performance over the prior two years is below that of its peer group, it will have more income-increasing accruals management in the current year. When the dependent variable is abnormal total accruals, the coefficient on $\operatorname{MisS}_{i \mu(t-1, t-2)}$ is positive $(0.0415)$ and significant at the $1 \%$ level $(\mathrm{p}<0.0001)$. Those firm years have abnormal total accruals that are higher on average by $4.15 \%$ of assets 
compared to the rest of the sample. When the dependent variable is abnormal current accruals, the coefficient on $\operatorname{Miss}_{i \mu(t-1, t-2)}$ is positive (0.0373) and significant at the $1 \%$ level $(\mathrm{p}<0.0001)$. Those firm years have abnormal current accruals that are higher on average by $3.73 \%$ of assets compared to the rest of the sample.

Table 11 provides the regression results of equation (14). The interaction term Achieve $_{i t} * U n P \operatorname{erf} f_{i \mu(t-1, t-2)}$ is positive and significant, indicating that firms both just achieving (achieve within the range of 0.05) current year's peer performance benchmark and just missing (miss within the range of -0.05 ) prior two year's mean peer performance benchmark, are more likely to manage accruals in the current year.

\section{Real Activities Manipulation Tests}

Table 12 provides the regression results of equation (15). For both measures, the coefficients on the variable of interest $M i s s_{i \mu(t-1, t-2)}$ is positive and significant, suggesting that if a firm's average performance over the prior two years is below that of its peer group, it will have more income-increasing real activities manipulation in the current year. When the dependent variable is unexpected abnormal level of discretionary expenditures, the coefficient on $\operatorname{Miss}_{i \mu(t-1, t-2)}$ is positive (0.0042) and significant at the $1 \%$ level $(\mathrm{p}<0.0001)$. Those firm years have unexpected abnormal level of discretionary expenditures that are higher on average by $0.42 \%$ of assets compared to the rest of the sample. When the dependent variable is abnormal cash flow from operations, the coefficient on $\operatorname{Miss}_{i \mu(t-1, t-2)}$ is positive (0.0123) and significant at the $1 \%$ level $(\mathrm{p}<0.0001)$. Those firm years have abnormal cash flow from operations that are higher on average by $1.23 \%$ of assets compared to the rest of the sample. 
Table 13 provides the regression results of equation (16). The coefficient on Achieve $_{i t} * \operatorname{UnPerf}_{i \mu(t-1, t-2)}$ is positive and significant regressed on abnormal cash flows, indicating firms just achieving (achieve within the range of 0.05) current year's peer performance benchmark and just missing (miss within the range of -0.05) prior two year's peer performance benchmark have higher abnormal cash flows compared to the rest of the sample provide evidence that firms use real activities to increase cash to boost earnings to achieve the peer performance benchmark. However, when the dependent variable is $r m U D I S X_{i t}$, the coefficient on the interaction term is not significant.

\section{Missing Current Year's Expected Peer Performance Benchmark}

Tables 14 through 17 provide evidence supporting H3. First, I estimate equations (17) and (18) using two proxies for accruals management as dependent variables- (a) abnormal total accruals, (b) abnormal current accruals. Second, I estimate equations (19) and (20) using two proxies for real activities manipulation as dependent variables- (a) unexpected abnormal level of discretionary expenditures, (b) abnormal cash flow from operations.

\section{Accruals Management Tests}

Table 14 provides the regression results of equation (17). For both measures, the coefficients on the variable of interest $M i s s_{i t}$ is positive and significant, suggesting that if a firm's expected performance is below its peer group's expected performance, incomeincreasing accruals management will be greater in the current year than if the firm's expected performance exceeds that of its peers. When the dependent variable is abnormal total accruals, the coefficient on $E M i s s_{i t}$ is positive (0.0249) and significant at the $1 \%$ 
level $(\mathrm{p}<0.0001)$. Those firm years have abnormal total accruals that are higher on average by $2.49 \%$ of assets compared to the rest of the sample. When the dependent variable is abnormal current accruals, the coefficient on EMiss $_{i t}$ is positive $(0.0221)$ and significant at the $1 \%$ level $(\mathrm{p}<0.0001)$. Those firm years have abnormal current accruals that are higher on average by $2.21 \%$ of assets compared to the rest of the sample.

Table 15 provides the regression results of equation (18). The coefficients on the interaction term Achieve $_{i t} * E U n P e r f_{i t}$ is positive and significant, indicating that firms just achieving (achieve within the range of 0.05) current year's peer performance benchmark and firms just missing (miss within the range of -0.05) current year's expected peer performance benchmark are more likely to manage accruals upward to achieve the peer performance benchmark.

\section{Real Activities Manipulation Tests}

Table 16 provides the regression results of equation (19). For both measures, the coefficients on the variable of interest $M i s s_{i t}$ is not significant. It fails to provide evidence that if a firm's expected performance is below its peer group's expected performance, income-increasing real activities manipulation will be greater in the current year than if the firm's expected performance exceeds that of its peers.

Table 17 provides the regression results of equation (20). When the dependent variable is abnormal cash flows, the coefficient on the interaction term Achieve $_{i t}$ * EUnPerf $f_{i t}$, capturing the incremental effect on real activities manipulation of firms that both just achieve (achieve within the range of 0.05) current year's peer performance benchmark and just miss (miss within the range of -0.05) current year's expected peer 
performance benchmark, is positive and significant, indicating those firms possess higher abnormal cash flows during the year. However, for the unexpected abnormal level of discretionary expenditures, the coefficient on the interaction term is not significant.

\section{Missing First Three Quarter's Cumulative Peer Performance Benchmark}

Tables 18 through 21 provide evidence in line with H4. First, I estimate equations (21) and (22) using two proxies for accruals management as dependent variables- (a) abnormal total accruals, (b) abnormal current accruals. Second, I estimate equation (23)(24) using two proxies for real activities manipulation as dependent variables- (a) unexpected abnormal level of discretionary expenditures, (b) abnormal cash flow from operations.

\section{Accruals Management Tests}

Table 18 provides the regression results of equation (21). For both measures, the coefficients on the variable of interest $\operatorname{Miss}_{i t} \sum(q 1, q 2, q 3)$ is positive and significant, suggesting that firm's with cumulative performance that is lower than that of its peer group through the first three quarters of the fiscal year exhibit more upward accruals management in the fourth quarter of their fiscal year. When the dependent variable is abnormal total accruals, the coefficient on $\operatorname{Miss}_{i t} \sum(q 1, q 2, q 3)$ is positive (0.0098) and significant at the $1 \%$ level $(\mathrm{p}<0.0001)$. Those fourth quarters have abnormal total accruals that are higher on average by $0.98 \%$ of assets compared to the rest of the sample. When the dependent variable is abnormal current accruals, the coefficient on $\operatorname{Miss}_{i t}(q 1, q 2, q 3)$ is positive $(0.0111)$ and significant at the $1 \%$ level $(\mathrm{p}<0.0001)$. Those fourth quarter have 
abnormal current accruals that are higher on average by $1.11 \%$ of assets compared to the rest of the sample.

Table 19 provides the regression results of equation (22). For both measures, the interaction term of Achieve $_{i t} * \operatorname{UnPerf} f_{i t} \sum(q 1, q 2, q 3)$ has positive coefficients. This indicates that firms just missing (miss by the range of -0.05) the first three quarter's cumulative peer performance benchmark and achieving the whole year's peer performance benchmark, has additionally more abnormal accruals, which provide evidence that using quarterly data, firms manage accruals to achieve the peer performance benchmark.

\section{Real Activities Manipulation Tests}

Table 20 provides the regression results of equation (23). For both measures, the coefficient on the variable of interest $\operatorname{Miss}_{i t} \sum(q 1, q 2, q 3)$ is negative and significant, suggesting that firm's with cumulative performance that is lower than that of its peer group through the first three quarters of the fiscal year will exhibit more upward real activities manipulation in the fourth quarter of their fiscal year. When the dependent variable is unexpected abnormal level of discretionary expenditures, the coefficient on

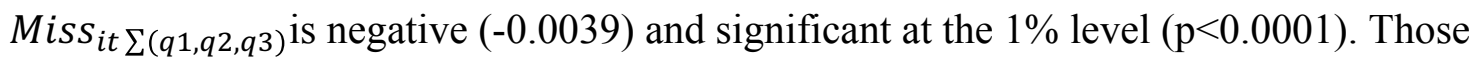
firm years have unexpected abnormal level of discretionary expenditures that are lower on average by $0.39 \%$ of assets compared to the rest of the sample. When the dependent variable is abnormal cash flow from operations, the coefficient on $\operatorname{Miss}_{i t} \sum(q 1, q 2, q 3)$ is negative $(-0.0058)$ and significant at the $1 \%$ level $(p<0.0001)$. Those firm years have 
abnormal cash flow from operations that are higher on average by $0.58 \%$ of assets compared to the rest of the sample.

Table 21 provides the regression results of equation (24). When abnormal cash flow is the dependent variable, the interaction term of $\operatorname{Achieve}_{i t} * \operatorname{UnPerf}_{\text {it } \Sigma(q 1, q 2, q 3)}$ has a positive coefficient. This indicates that firms just missing (miss by the range of 0.05) the first three quarter's cumulative peer performance benchmark and achieving the whole year's peer performance benchmark, has additionally more abnormal cash flow, which provide evidence that using quarterly data, firms manipulate real activities to achieve the peer performance benchmark. However, when unexpected abnormal level of discretionary expenditures is the dependent variable, the coefficient of interaction term of Achieve $_{i t} * \operatorname{UnPerf}_{\text {it } \sum(q 1, q 2, q 3)}$ does not possess the expected sign.

\section{Logistic Regression Results}

Tables 22 and 23 report the results of equation (25). The coefficient on the interaction term Achieve $_{i t} * A T A_{i t}\left(\right.$ Achieve $\left._{i t} * A C A_{i t}\right)$ captures the additional probability to restate current year's earnings if firms just achieve (achieving within the range of 0.05 ) current year's peer performance benchmark with the help of abnormal accrual. The effect is quite large, the odds of restating current period earnings in the future increase by $93.93 \%(136.23 \%)$.

Tables 24 through 31 report the results of equation (26). In Tables 24 and 25, the coefficients on $A c h_{i t-} M i s_{i t-1} * A T A_{i t}\left(A c h_{i t-} M i s_{i t-1} * A C A_{i t}\right)$ are positive and significant, suggesting that the level of abnormal accruals will increase the probability of restatement under the situation that if firm miss the prior year's peer performance 
benchmark and achieve current year's peer performance benchmark. In other words, if firms use abnormal accruals to help them achieve current year's peer performance benchmark, they are more likely to restate their current year's financial statements in the future.

In Tables 26 and 27, the coefficients on the interaction terms $A c h_{i t-} M i s_{i \mu(t-1 . t-2)} * A T A_{i t}\left(\right.$ Ach $\left._{i t_{-}} M i s_{i \mu(t-1 . t-2)} * A C A_{i t}\right)$ are positive and significant, suggesting that the level of abnormal accruals will increase the probability of restatement under the situation that if firm miss the prior two year's peer performance benchmark and achieve current year's peer performance benchmark.

In Tables 28 and 29, the coefficients on the interaction term Ach $_{i t} E M i s_{i t} *$ $A T A_{i t}\left(\right.$ Ach $\left._{i t} E M i s_{i t} * A C A_{i t}\right)$ are positive but not significant.

In Tables 30 and 31, the coefficients on the interaction terms $A c h_{M i s_{i t}(q 1, q 2, q 3)}$ * $A T A_{i t(q 4)}\left(A c h_{i t \_} E M i s_{i t} * A C A_{i t}\right)$ are positive and significant, suggesting that the level of abnormal accruals will increase the probability of restatement if firms miss the first three quarter's cumulative peer performance benchmark and achieve the current year's peer performance benchmark. In other words, firms under the pressure of achieving the current year's peer performance benchmark and use accruals to achieve the current year's peer performance benchmark are more likely to restate their current year's financial statements in the future.

Tables 32 through 35 report the regression of equation (27). As expected, all

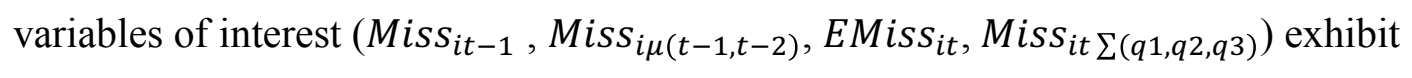


significant positive effects on the probability of restatement in the future. If firms fail to reach peer performance in the prior year (i.e., $M i s s_{i t-1}=1$ ), the odds of restated current period earnings in the future increase by 14.14 percent. If firms fail to reach the average peer performance benchmark over the prior two years (i. e. , $M i s s_{i \mu(t-1, t-2)}=1$ ), the odds of restating current period earnings in the future increase by $16.51 \%$. If firms fail to reach the expected peer performance benchmark (i. e. , EMiss ${ }_{i t}=1$ ), the odds of restating current year's earnings in the future increase by $11.42 \%$. For firms fail to reach the cumulative peer performance benchmark over the first three quarters (i.e., $\left.\operatorname{Miss}_{i t} \sum(q 1, q 2, q 3)=1\right)$, the odds of restating the fourth quarter's earnings in the future increase by $18.88 \%$.

\section{CONCLUSION}

This dissertation is, to the best of my knowledge, the first study to document the impact of achieving peer performance on earnings management decisions. The existing literature has focused on earnings management behavior to achieve three earnings thresholds: avoid negative earnings, avoid earnings decreases, and avoid negative surprises. Other than these three benchmarks, peer performance is another important earnings target, yet is largely ignored in the extant literature.

In my dissertation, I examine whether the peer performance benchmark drives earnings management. I identify four situations when a firm is likely to manage earnings 
to meet or beat its peer group's performance, and provide evidence that firms exhibit more income-increasing accruals management in the current year under those situations: 1) when firms' prior year performance is below that of their peer group; 2) when firms' average performance over the prior two years is below that of its peer group; 3 ) when firms' expected performance is below its peer group's expected performance; and 4) when firms with cumulative performance that is lower than that of its peer group through the first three quarters of the fiscal year exhibit more upward accruals management in the fourth quarter. I also find that that firms exhibit more increase-increasing real activities manipulation in the current year: 1) when firms' prior year performance is below that of their peer group; 2) when firms' average performance over the prior two years is below that of its peer group.

I also investigate the likelihood of future restatements of financial statements for firm-year observations that are subject to earnings management to achieve peer performance. As the restatement of financial statements is a consequence of prior earnings management, I show that firms under the following four situations are more likely to restate current earnings in the future. The influence of peer performance on earnings management behavior implies that although the RPE can improve compensation contracts and efficiency in implementing compensation plans, it can have unintended consequences as it may induce income-increasing earnings management. The presence of peer performance benchmark also suggests that the decision to manage earnings is not made in isolation. The historical and current performance information from peer firms is important factors affecting an individual manager's proclivity to manage earnings. 
I plan to extend this line of research by investigating the following research questions in my future studies. First, can compensation committees detect earnings management and do they revise their compensation contracts subsequently? Second, how the career concerns of CEOs is associated with the earnings management decision when firms' executives are subject to RPE? Third, how do the analysts' identified peers differ from the firms' identified peers for RPE, and how this difference affects financial reporting behavior and analysts' forecast errors? Finally, does consistently better performance compared to peer firms impact firms costs of equity and debt capital? 


\section{REFERENCES}

Abarbanell, J., and R. Lehavy. 2003. Biased forecasts or biased earnings? The role of reported earnings in explaining apparent bias and over/underreaction in analysts' earnings forecasts. Journal of Accounting and Economics 36 (1): 105-146.

Aggarwal, R., and A. Samwick. 1999a. The other side of the trade-off: the impact of risk on executive compensation. Journal of Political Economy 107 (1): 65-105.

Aggarwal, R., and A. Samwick. 1999b. Executive compensation, strategic competition, and relative performance evaluation: theory and evidence. Journal of Finance 54 (6):1999-2043.

Albuquerque, A. 2009. Peer firms in relative performance evaluation. Journal of Accounting and Economics 48 (1): 69-89.

Albuquerque, A. 2014. Do Growth-Option Firms Use Less Relative Performance Evaluation? The Accounting Review 89 (1): 27-60.

Allegion, Plc. 2014. SEC Form DEF 14A. Retrieved from SEC EDGAR website http://www.sec.gov/edgar.shtml

Allen, E., C. Larson, and R. Sloan. 2013. Accrual reversals, earnings and stock returns. Journal of Accounting and Economics, 56 (1): 113-129.

Altman, E. 1968. Financial ratios, discriminate analysis and the prediction of corporate bankruptcy. Journal of Finance, 23 (4): 589-609.

Altman, E. 2000. Predicting financial distress of companies: revisiting the Z-score and ZETA models. Working paper, New York University.

Analog Device. Inc. 2014. SEC Form DEF 14A. Retrieved from SEC EDGAR website http://www.sec.gov/edgar.shtml

Antle, R., and A. Smith. 1986. An empirical investigation of the relative performance evaluation of corporate executives. Journal of Accounting Research 24 (1): 1-39.

Armstrong, C., A. Jagolinzer, and D. Larcker. 2010. Chief executive officer equity incentives and accounting irregularities. Journal of Accounting Research 48 (2): 225-271.

Ashbaugh, H., R. LaFond, and B. Mayhew. 2003. Do nonaudit services compromise auditor independence? Further evidence. The Accounting Review 78 (3): 611-639.

Avery Dennison Corp. 2011. SEC Form DEF 14A. Retrieved from SEC EDGAR website http://www.sec.gov/edgar.shtml 
Ayers, B., J. Jiang, and P.Yeung. 2006. Discretionary accruals and earnings management: An analysis of pseudo earnings targets. The Accounting Review 81 (3): 617-652.

Baber, W., P. Fairfield, and J. Haggard. 1991. The effect of concern about reported income on discretionary spending decisions: The case of research and development. The Accounting Review 66 (4): 818-829.

Badertscher, B. 2011. Overvaluation and the choice of alternative earnings management mechanisms. The Accounting Review 86 (5): 1491-1518.

Baker, G. (2002). Distortion and risk in optimal incentive contracts. Journal of Human Resources 37 (4): 728-751.

Barro, J., and R. Barro. 1990. Pay, performance, and turnover of bank CEOs. Journal of Labor Economics 8 (4): 448-481.

Barth, M., J. Elliott, and M. Finn. 1999. Market rewards associated with patterns of increasing earnings. Journal of Accounting Research 37 (2): 387-413.

Barua, A., S. Lin, and A. Sbaraglia. 2010. Earnings management using discontinued operations. The Accounting Review 85 (5):1485-1509.

Barton, J., and P. Simko. 2002. The balance sheet as an earnings management constraint. The Accounting Review 77(s-1): 1-27.

Bartov, E., D. Givoly, and C. Hayn. 2002. The rewards to meeting or beating earnings expectations. Journal of Accounting and Economics 33 (2): 173-204.

Bed Bath and Beyond. 2014. SEC Form DEF 14A. Retrieved from SEC EDGAR website http://www.sec.gov/edgar.shtml

Beatty, A., S. Liao, and J. Yu. 2013. The spillover effect of fraudulent financial reporting on peer firms' investments. Journal of Accounting and Economics 55 (2): 183-205.

Beaver, W., M. McNichols, and K. Nelson. 2003. Management of the loss reserve accrual and the distribution of earnings in the property-casualty insurance industry. Journal of Accounting and Economics 35 (3): 347-376.

Beaver, W., M. McNichols, and K. Nelson. 2007. An alternative interpretation of the discontinuity in earnings distributions. Review of Accounting Studies 12 (4): 525-556.

Bergstresser, D., and T. Philippon. 2006. CEO incentives and earnings management. Journal of Financial Economics 80 (3): 511-529.

Bertrand, M., and S. Mullainathan. 2001. Are CEOs rewarded for luck? The ones without principals are. The Quarterly Journal of Economics 116 (3): 901-932. 
Bhojraj, S., and C. Lee. 2002. Who Is My Peer? A Valuation-Based Approach to the Selection of Comparable Firms. Journal of Accounting Research 40 (2): 407-439.

Boni, L., and K. Womack. 2006. Analysts, industries, and price momentum. Journal of Financial and Quantitative Analysis 41 (01): 85-109.

Bradshaw, M., S. Richardson, and R. Sloan. 2001. Do analysts and auditors use information in accruals? Journal of Accounting Research 39 (1): 45-74.

Bradshaw, M. 2011. Analysts' forecasts: what do we know after decades of work? Working paper, Boston College.

Brown, L., and M. Caylor. 2005. A temporal analysis of quarterly earnings thresholds: Propensities and valuation consequences. The Accounting Review 80 (2): 423-440.

Burgstahler, D., and I. Dichev. 1997. Earnings management to avoid earnings decreases and losses. Journal of Accounting and Economics 24 (1): 99-126.

Burgstahler, D., and M. Eames. 2006. Management of earnings and analysts' forecasts to achieve zero and small positive earnings surprises. Journal of Business Finance \& Accounting 33 (5-6): 633-652.

Burns, N., and S. Kedia. 2006. The impact of performance-based compensation on misreporting. Journal of Financial Economics 79 (1): 35-67.

Bushee, B. 1998. The influence of institutional investors on myopic R\&D investment behavior. The Accounting review 73 (3): 305-333.

Chan, L., J. Lakonishok, and B. Swaminathan. 2007. Industry classifications and return comovement. Financial Analysts Journal 63 (6): 56-70.

Cheng, Q., and T. Warfield. 2005. Equity incentives and earnings management. The Accounting Review. 80 (2): 441-476.

Cohen, D., A. Dey, and T. Lys. 2008. Real and accrual-based earnings management in the pre-and post-Sarbanes-Oxley periods. The Accounting Review 83 (3): 757-787.

De Franco, G., S. Kothari, and R. Verdi. 2011. The benefits of financial statement comparability. Journal of Accounting Research 49 (4): 895-931.

De Franco, G., O. Hope, and S. Larocque. 2012. Analysts' choice of peer companies. Review of Accounting Studies 20 (1): 82-109

Dechow, P., W. Ge, C. Larson, and R. Sloan. 2011. Predicting Material Accounting Misstatements. Contemporary Accounting Research 28 (1): 17-82. 
Dechow, P., S. Richardson, and I. Tuna. 2003. Why are earnings kinky? An examination of the earnings management explanation. Review of Accounting Studies 8 (2-3): 355-384.

Dechow, P., and R. Sloan. 1991. Executive incentives and the horizon problem: An empirical investigation. Journal of Accounting and Economics 14 (1): 51-89.

Dechow, P., R. Sloan, and A. Sweeney. 1995. Detecting earnings management. The Accounting Review 70 (2): 193-225.

Dechow, P., and C. Shakespear. 2009. Do managers time securitization transactions to obtain accounting benefits? The Accounting Review 84 (1): 99-132.

DeFond, M., and C. Park. 1997. Smoothing income in anticipation of future earnings. Journal of Accounting and Economics 23 (2): 115-139.

DeFond, M., and C. Park. 1999. The effect of competition on CEO turnover. Journal of Accounting and Economics 27 (1): 35-56.

Degeorge, F., J. Patel, and R. Zeckhauser. 1999. Earnings management to exceed thresholds. The Journal of Business 72 (1): 1-33.

Desai, H., S. Krishnamurthy, and K. Venkataraman. 2006. Do short sellers target firms with poor earnings quality? Evidence from earnings restatements. Review of Accounting Studies 11 (1): 71-90.

Durtschi, C., and P. Easton. 2005. Earnings management? The shapes of the frequency distributions of earnings metrics are not evidence ipso facto. Journal of Accounting Research 43 (4): 557-592.

Ecker, F., J. Francis, P. Olsson, and K. Schipper. 2011. Peer firm selection for discretionary accruals models. Working paper, Duke University.

Efendi, J., A. Srivastava, and E. Swanson. 2007. Why do corporate managers misstate financial statements? The role of option compensation and other factors. Journal of Financial Economics 85 (3): 667-708.

Elgers, P., R. Pfeiffer, and S. Porter. 2003. Anticipatory income smoothing: a reexamination. Journal of Accounting and Economics 35 (3): 405-422.

Ettredge, M., S. Scholz, K. Smith, and L. Sun. 2010. How do restatements begin? Evidence of earnings management preceding restated financial reports. Journal of Business Finance \& Accounting 37 (3-4): 332-355.

Fan, Y., A. Barua, W. Cready, and W. Thomas. 2010. Managing earnings using classification shifting: Evidence from quarterly special items. The Accounting Review 85 (4): 1303-1323. 
Garvey, G., and T. Milbourn. 2003. Incentive compensation when executives can hedge the market: Evidence of relative performance evaluation in the cross section. The Journal of Finance 58 (4): 1557-1582.

Gibbons, R., and K. Murphy. 1990. Relative performance evaluation for chief executive officers. Industrial \& Labor Relations Review 43 (3): 30-51.

Gong, G., L. Li, and J. Shin. 2011. Relative performance evaluation and related peer groups in executive compensation contracts. The Accounting Review 86 (3): 1007-1043.

Graham, J., C. Harvey, and S. Rajgopal. 2005. The economic implications of corporate financial reporting. Journal of Accounting and Economics 40 (1): 3-73.

Guenther, D. 1994. Earnings management in response to corporate tax rate changes: Evidence from the 1986 tax reform act. The Accounting Review 69 (1): 230-243.

Guidry, F., A. Leone, and S. Rock. 1999. Earnings-based bonus plans and earnings management by business-unit managers. Journal of Accounting and Economics 26 (1): 113-142.

Haw, I., S. Ho, and A. Li. 2011. Corporate Governance and Earnings Management by Classification Shifting. Contemporary Accounting Research 28(2): 517-553.

Healy, P. 1985. The effect of bonus schemes on accounting decisions. Journal of Accounting and Economics 7 (1): 85-107.

Healy, P., and K. Palepu. 2007. Business analysis and valuation: Using financial statements (4th ed.) Mason, Ohio: Thomson Southwestern.

Healy, P., and J. Wahlen. 1999. A Review of the Earnings Management Literature and Its Implications for Standard Setting. Accounting Horizons 13 (4): 365-383.

Hennes, K., A. Leone, and B. Miller. 2008. The importance of distinguishing errors from irregularities in restatement research: The case of restatements and $\mathrm{CEO} / \mathrm{CFO}$ turnover. The Accounting Review 83 (6): 1487-1519.

Himmelberg, C., and R. Hubbard. 2000. Incentive pay and the market for CEOs: an analysis of pay-for-performance sensitivity. Working paper, Columbia University, New York, NY.

Holmstrom, B. 1982. Moral hazard in teams. The Bell Journal of Economics 13(2): 324340 .

Holthausen, R., D. Larcker, and R. Sloan. 1995. Annual bonus schemes and the manipulation of earnings. Journal of Accounting and Economics 19 (1): 29-74. 
Hribar, P., N. Jenkins, and W. Johnson. 2006. Stock repurchases as an earnings management device. Journal of Accounting and Economics 41 (1): 3-27.

Jacob, J., and B. Jorgensen. 2007. Earnings management and accounting income aggregation. Journal of Accounting and Economics 43 (2): 369-390.

Janakiraman, S., R. Lambert, and D. Larcker. 1992. An empirical investigation of the relative performance evaluation hypothesis. Journal of Accounting Research 30 (1): 5369.

Jones, J. 1991. Earnings Management During Import Relief Investigations. Journal of Accounting Research 29 (2): 193-228.

Kahneman, D., and A. Tversky. 1979. Prospect theory: An analysis of decision under risk. Econometrica 47 (2): 263-291.

Kasznik, R., and M. McNichols. 2002. Does meeting earnings expectations matter? Evidence from analyst forecast revisions and share prices. Journal of Accounting Research 40 (3): 727-759.

Kedia, S., K. Koh, and S. Rajgopal. 2015. Evidence on Contagion in Earnings Management. The Accounting Review. Forthcoming.

Kerstein, J., and A. Rai. 2007. Intra-year shifts in the earnings distribution and their implications for earnings management. Journal of Accounting and Economics 44 (3): 399-419.

Kinney, M., and R. Trezevant. 1997. The use of special items to manage earnings and perceptions. Journal of Financial Statement Analysis 3 (1): 45-53.

Kothari, S., A. Leone, and C. Wasley. 2005. Performance matched discretionary accrual measures. Journal of Accounting and Economics 39 (1): 163-197.

Leary, M., and M. Roberts. 2014. Do peer firms affect corporate financial policy? The Journal of Finance 69 (1): 139-178.

Lee, L. 2011. Incentives to inflate reported cash from operations using classification and timing. The Accounting Review 87 (1): 1-33.

Li, V. (2015). Do False Financial Statements Distort Peer Firms' Decisions? The Accounting Review. Forthcoming.

Lopez, T., and L. Rees. 2002. The effect of beating and missing analysts' forecasts on the information content of unexpected earnings. Journal of Accounting, Auditing \& Finance 17 (2): 155-184. 
Matsumoto, D. 2002. Management's incentives to avoid negative earnings surprises. The Accounting Review 77 (3): 483-514.

Merchant, K. 1989. Rewarding results: Motivating profit center managers. Boston, MA: Harvard Business School Press.

Payne, J., and S. Robb. 2000. Earnings management: The effect of ex ante earnings expectations. Journal of Accounting, Auditing \& Finance 15 (4): 371-392.

Rajgopal, S., T. Shevlin, and V. Zamora. 2006. CEOs' outside employment opportunities and the lack of relative performance evaluation in compensation contracts. The Journal of Finance 61 (4): 1813-1844.

Phillips, J., M. Pincus, and S. Rego. 2003. Earnings management: New evidence based on deferred tax expense. The Accounting Review 78 (2): 491-521.

Richardson, S., A. Tuna, and M. Wu. 2002. Predicting earnings management: The case of earnings restatements. Working Paper. London Business School.

Roychowdhury, S. 2006. Earnings management through real activities manipulation. Journal of Accounting and Economics 42(3): 335-370.

Rudegair, Peter. 2015. LendingClub Draws Competitors in Spades. The Wall Street Journal, 05 May. Available at: http://www.wsj.com/articles/lendingclubs-loss-narrows1430857390

Skinner, D., and R. Sloan. 2002. Earnings surprises, growth expectations, and stock returns or don't let an earnings torpedo sink your portfolio. Review of Accounting Studies 7 (2-3): 289-312.

Stickney, C., P. Brown, and J. Wahlen. 2007. Financial reporting, financial statement analysis, and valuation: A strategic perspective (6th ed.). Mason, Ohio: Thomson/SouthWestern.

Teoh, S., T. Wong, and G. Rao. (1998). Are accruals during initial public offerings opportunistic?. Review of Accounting Studies 3(1-2): 175-208.

Teoh, S., I. Welch, and T. Wong. 1998. Earnings management and the underperformance of seasoned equity offerings. Journal of Financial Economics 50 (1): 63-99.

Warfield, T., J. Wild, and K. Wild. 1995. Managerial ownership, accounting choices, and informativeness of earnings. Journal of Accounting and Economics 20 (1): 61-91.

Zang, A. 2012. Evidence on the trade-off between real activities manipulation and accrual-based earnings management. The Accounting Review 87 (2): 675-703. 


\section{Table 1}

\section{Sample Derivation}

\section{Panel A: Sample Derivation - Abnormal Accrual Measures}

Number of firm-year found in Compustat 1988-2012

116,635

Number of firm-year that having non-missing values for discretionary accrual measures

Number of firm-year above found in $\mathrm{I} / \mathrm{B} / \mathrm{E} / \mathrm{S}$

Number of firm-year excluding firms in financial and utility industries

Number of firm-fourth-quarter found in Compustat 1988-2012

167,982

Number of firm-fourth-quarter that having non-missing values discretionary accrual measures

Number of firm-fourth-quarter excluding firms in financial and utility industries

\section{Panel B: Sample Derivation - Real Earnings Management Measures}

Number of firm-year found in Compustat 1988-2012

116,635

Number of firm-year that having non-missing values for real earnings management measures

Number of firm-year above found in $\mathrm{I} / \mathrm{B} / \mathrm{E} / \mathrm{S}$

Number of firm-fourth-quarter found in Compustat 1988-2012

Number of firm-fourth-quarter with non-missing values for real earnings management measures

\section{Panel C: Sample Derivation - Restatement Measures}

Number of firm-year found in Compustat 1988-2012

Number of firm-year that having non-missing values

Number of firm-fourth-quarter found in Compustat 1988-2012

Table 1 panel A and panel B provide the sample derivation for the tests on earnings management measured using the 1) discretionary accrual 2) real earnings management measures. Table 1 panel C provides the sample derivation for the logistic regression on the future restatement. 
Table 2

\section{Descriptive Statistics of Variables}

\begin{tabular}{c|c|c|c|c|c|c}
\hline & $\mathbf{N}$ & Mean & SD & $\mathbf{2 5 \%}$ & Median & $\mathbf{7 5 \%}$ \\
\hline Achieve $_{i t}$ & 47968 & 0.2541 & 0.4354 & 0.0000 & 0.0000 & 1.0000 \\
Miss $_{i t-1}$ & 47968 & 0.5006 & 0.5000 & 0.0000 & 1.0000 & 1.0000 \\
Miss $_{i \mu(t-1, t-2)}$ & 47968 & 0.4999 & 0.5000 & 0.0000 & 0.0000 & 1.0000 \\
EMiss $_{i t}$ & 47968 & 0.5020 & 0.5000 & 0.0000 & 1.0000 & 1.0000 \\
UnPerf $_{i t-1}$ & 47968 & 0.2528 & 0.4346 & 0.0000 & 0.0000 & 1.0000 \\
UnPerf & \\
EUn $(t-1, t-2)$ & 47968 & 0.2537 & 0.4351 & 0.0000 & 0.0000 & 1.0000 \\
ATP $_{i t}$ & 48643 & 0.3355 & 0.4722 & 0.0000 & 0.0000 & 1.0000 \\
ACA $_{i t}$ & 47968 & -0.0176 & 0.1147 & -0.0595 & -0.0127 & 0.0321 \\
ROA $_{t}$ & 47968 & -0.0132 & 0.1075 & -0.0517 & -0.0114 & 0.0284 \\
BM $_{i t}$ & 47968 & 0.0071 & 0.1868 & -0.0086 & 0.0455 & 0.0900 \\
LogAT $_{i t}$ & 47968 & 0.5607 & 0.7947 & 0.2684 & 0.4566 & 0.7329 \\
LEV $_{i t}$ & 47968 & 0.4751 & 0.2496 & 0.2918 & 0.4657 & 0.6202 \\
rmUDISX $_{i t}$ & 46930 & 0.0028 & 0.1005 & -0.0373 & 0.0021 & 0.0430 \\
rmCASH $_{i t}$ & 46930 & 0.0263 & 0.1507 & -0.0344 & 0.0310 & 0.0998 \\
\hline
\end{tabular}

Achieve $_{i t}$ is a dummy variable and it equals one if firm $i$ 's current year's performance $\left(R O A_{t}\right)$ is above the peer group by no more than 0.05 . In other words, $R O A_{t}-\operatorname{Peer}\left(R O A_{t}\right)$ is within the range of $(0,0.05)$. $M i s s_{i t-1}$ is a dummy variable and it equals one if firm $i$ 's prior year's performance $\left(R O A_{t-1}\right)$ is below that of its peer group.

Miss $_{i \mu(t-1, t-2)}$ is a dummy variable and it equals one if firm $i$ 's average performance $\left(R O A_{\mu(t-1, t-2)}\right)$ of the past two years is below that of its peer group. $R O A_{\mu(t-1, t-2)}$ is calculated using $\frac{R O A_{t-2}+R O A_{t-1}}{2}$.

$E M i s s_{i t}$ is a dummy variable and it equals one if if firm $i$ 's expected performance Forecasted_EPS $S_{t}$ at year $t$ is below its peer group's expected performance for year $t$. Firm i's expected performance

Forecasted_EPS $S_{t}$ is calculated using analysts' consensus forecasted EPS scaled by scaled by assets per share at the beginning of the fiscal year. Consensus analyst forecasted EPS are the mean analysts' forecasts for the next period.

UnPerf $f_{i t-1}$ is a dummy variable and it equals one if firm $i$ 's prior year's performance $\left(R O A_{t-1}\right)$ is below that of its peer group by not more than 0.05 . To be more specific, $R O A_{t-1}-\operatorname{Peer}\left(R O A_{t-1}\right)$ is within the range of $(-0.05,0)$.

$\operatorname{UnPerf} f_{i \mu(t-1, t-2)}$ is a dummy variable and it equals one if firm $i$ 's average performance $\left(R O A_{\mu(t-1, t-2)}\right)$ of the past two years is below that of its peer group by no more than 0.05 . In other words, $R O A_{\mu(t-1, t-2)}-$ $\operatorname{Peer}\left(R O A_{\mu(t-1, t-2)}\right)$ is within the range of $(-0.05,0) . R O A_{\mu(t-1, t-2)}$ is calculated using $\frac{R O A_{t-2}+R O A_{t-1}}{2}$. EUnPerf $f_{i t}$ is a dummy variable and it equals one if if firm $i$ 's expected performance Forecasted_EPS $S_{t}$ at year $t$ is below its peer group's expected performance by no more than 0.05 for year $t$. In other words, Forecasted_EPS - Peer $\left(\right.$ Forecasted $\left._{E P S_{t}}\right)$ is within $(-0.05,0)$. Firm i's expected performance

Forecasted_EPS $S_{t}$ is calculated using analysts' consensus forecasted EPS scaled by scaled by assets per 
share at the beginning of the fiscal year. Consensus analyst forecasted EPS are the mean analysts' forecasts for the next period.

$A T A_{i t}$ is abnormal total accruals, which is the firm-specific residuals derived from following equation estimated cross-sectionally for each industry-year combination:

$\frac{T A_{i t}}{A T_{i t-1}}=\varphi_{0}+\varphi_{1}\left(\frac{1}{A T_{i t-1}}\right)+\varphi_{2}\left(\frac{\Delta R E V_{i t}}{A T_{i t-1}}-\frac{\Delta R E C_{i t}}{A T_{i t-1}}\right)+\varphi_{3}\left(\frac{P P E_{i t}}{A T_{i t-1}}\right)+R O A_{t-1}+\varepsilon_{i t}$

$A C A_{i t}$ is abnormal current accruals, which is defined as the firm specific residuals from the following equation estimated cross-sectionally for each year-industry combination.

$\frac{C A_{i t}}{A_{i t-1}}=\varphi_{0}+\varphi_{1}\left(\frac{1}{A_{i t-1}}\right)+\varphi_{2}\left(\frac{\Delta R E V_{i t}}{A_{i t-1}}-\frac{\Delta R E C_{i t}}{A_{i t-1}}\right)+R O A_{t-1}+\varepsilon_{i t}$

$\operatorname{LogAT}_{i t}$ is the natural logarithm of total assets of firm $i$ for year $t . \mathrm{BM}_{i t}$ is the book value of equity divided by market value of equity in year $t$ for firm $i$. $\mathrm{ROA}_{i t}$ is return on assets defined as income before extraordinary items in year $t$ divided by the average of total assets. $L E V_{i t}$ is total liability divided by total assets in year $t$.

rmUDISX $_{i t}$ is the unexpected abnormal level of discretionary expenditures estimated following Zang (2012). First, estimate the abnormal level of discretionary expenditures $\left(\right.$ rmDISX $\left._{i t}\right)$ as the residuals from the regression below. The regression is estimated cross-sectionally for each year and each two-digit SIC code with at least ten observations.

$\frac{\text { DISX }_{i t}}{A_{i t-1}}=\alpha_{0}+\alpha_{1}\left(\frac{1}{A_{i t-1}}\right)+\alpha_{2}\left(\frac{S_{i t-1}}{A_{i t-1}}\right)+\varepsilon_{i t}$

Second, estimate the unexpected abnormal level of discretionary expenditures $\left(\mathrm{rmUDISX}_{i t}\right)$ as the residuals from the regression below. The regression is estimated cross-sectionally for each industry-year combination.

$\operatorname{rmDISX}_{i t}=\beta_{0}+\beta_{1}$ Market $_{\text {Share }_{i t-1}}+\beta_{2}$ ZSCORE $_{i t-1}+\beta_{3}$ TAX $_{\text {Rate }_{i t}}+\beta_{4}$ BIG $_{i t}+\beta_{5}$ NOA $_{i t-1}+$ $\beta_{6} C Y C L E_{i t-1}+\beta_{7} R O A_{i t}+\beta_{8} L o g A T_{i t}+\beta_{9} M t o B_{i t}+\beta_{10} E_{a r n}+\varepsilon_{i t}$

To be consistent with Zang (2012), the unexpected abnormal level of discretionary expenditures are multiplied by (-1) such that higher values indicate greater amounts of unexpected abnormal level of discretionary expenditures reduced by firms to increase reported earnings.

$\mathrm{rmCASH}_{i t}$ is the abnormal cash flow from operations estimated following Roychowdhury (2006), which is defined as the firm specific residuals from the following equation estimated cross-sectionally for each yearindustry combination.

$\frac{C F O_{t}}{A_{t-1}}=\alpha_{0}+\alpha_{1}\left(\frac{1}{A_{t-1}}\right)+\beta_{t}\left(\frac{S_{t}}{A_{t-1}}\right)+\beta_{2}\left(\frac{\Delta S_{t}}{A_{t-1}}\right)+\varepsilon_{t}$

where $A_{t}$ is the total assetss at the end of period t, $S_{t}$ the sales during period t and $\Delta S_{t}=S_{t}-S_{t-1}$ 
Table 3

\section{Correlation Matrix}

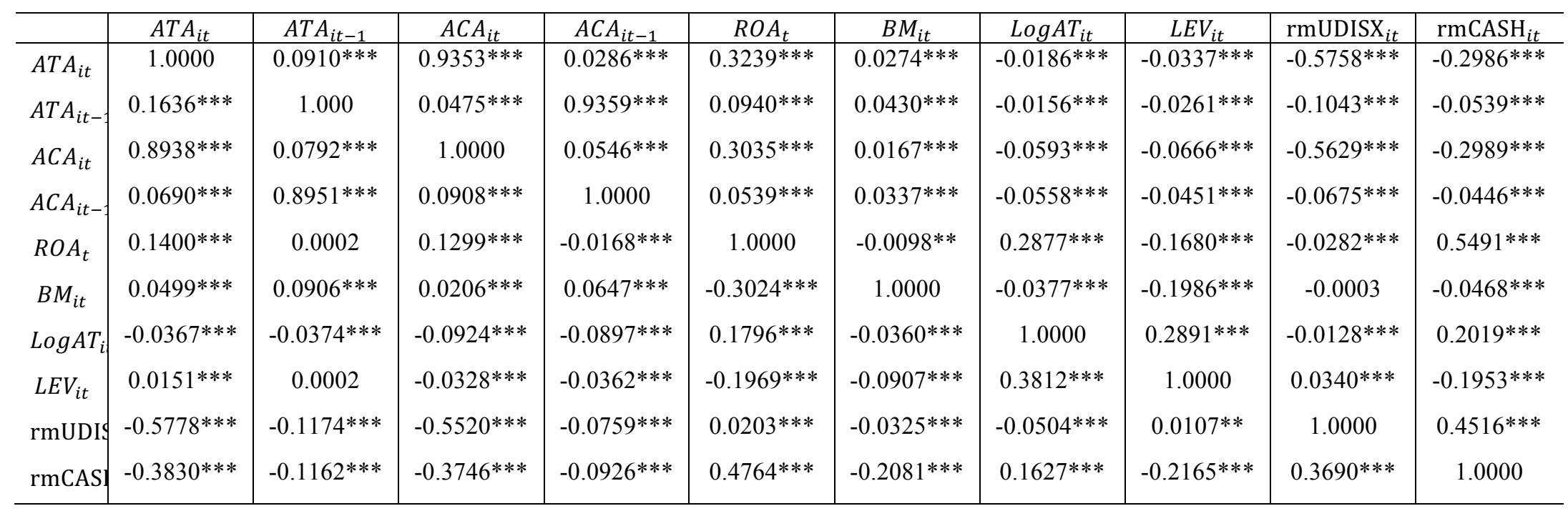

$*, * *, * * *$ denotes significance at $10 \%, 5 \%$ and $1 \%$ level respectively.

Upper diagonal cells are Pearson correlations and lower diagonal cells are Spearman correlations.

$A T A_{i t}$ is abnormal total accruals, which is the firm-specific residuals derived from following equation estimated cross-sectionally for each industry-year combination:

$\frac{T A_{i t}}{A T_{i t-1}}=\varphi_{0}+\varphi_{1}\left(\frac{1}{A T_{i t-1}}\right)+\varphi_{2}\left(\frac{\Delta R E V_{i t}}{A T_{i t-1}}-\frac{\Delta R E C_{i t}}{A T_{i t-1}}\right)+\varphi_{3}\left(\frac{P P E_{i t}}{A T_{i t-1}}\right)+R O A_{t-1}+\varepsilon_{i t}$

$A C A_{i t}$ is abnormal current accruals, which is defined as the firm specific residuals from the following equation estimated cross-sectionally for each yearindustry combination.

$\frac{C A_{i t}}{A_{i t-1}}=\varphi_{0}+\varphi_{1}\left(\frac{1}{A_{i t-1}}\right)+\varphi_{2}\left(\frac{\Delta R E V_{i t}}{A_{i t-1}}-\frac{\Delta R E C_{i t}}{A_{i t-1}}\right)+R O A_{t-1}+\varepsilon_{i t}$

$\operatorname{LogAT}_{i t}$ is the natural logarithm of total assets of firm $i$ for year $t$. BM $i t$ is the book value of equity divided by market value of equity in year $t$ for firm $i$. $\mathrm{ROA}_{i t}$ is return on assets defined as income before extraordinary items in year $t$ divided by the average of total assets. $L E V_{i t}$ is total liability divided by total assets in year $t$.

rmUDISX $_{i t}$ is the unexpected abnormal level of discretionary expenditures estimated following Zang (2012). First, estimate the abnormal level of discretionary expenditures $\left(\mathrm{rmDISX}_{i t}\right)$ as the residuals from the regression below. The regression is estimated cross-sectionally for each year and each two-digit SIC code with at least ten observations. 
$\frac{\operatorname{DISX}_{i t}}{A_{i t-1}}=\alpha_{0}+\alpha_{1}\left(\frac{1}{A_{i t-1}}\right)+\alpha_{2}\left(\frac{S_{i t-1}}{A_{i t-1}}\right)+\varepsilon_{i t}$

Second, estimate the unexpected abnormal level of discretionary expenditures $\left(\right.$ rmUDISX $\left._{i t}\right)$ as the residuals from the regression below. The regression is estimated cross-sectionally for each industry-year combination.

$\operatorname{rmDISX}_{i t}=\beta_{0}+\beta_{1}$ Market $_{\text {Share }_{i t-1}}+\beta_{2}$ ZSCORE $_{\text {it }-1}+\beta_{3}$ TAX $_{\text {Rate }_{i t}}+\beta_{4}$ BIG $_{i t}+\beta_{5}$ NOA $_{i t-1}+\beta_{6}$ CYCLE $_{i t-1}+\beta_{7}$ ROA $_{i t}+\beta_{8} L o g A T_{i t}+$

$\beta_{9}$ MtoB $_{i t}+\beta_{10}$ Earn $_{i t}+\varepsilon_{i t}$

To be consistent with Zang (2012), the unexpected abnormal level of discretionary expenditures are multiplied by (-1) such that higher values indicate greater amounts of unexpected abnormal level of discretionary expenditures reduced by firms to increase reported earnings.

$\mathrm{rmCASH}_{i t}$ is the abnormal cash flow from operations estimated following Roychowdhury (2006), which is defined as the firm specific residuals from the following equation estimated cross-sectionally for each year-industry combination.

$$
\frac{C F O_{t}}{A_{t-1}}=\alpha_{0}+\alpha_{1}\left(\frac{1}{A_{t-1}}\right)+\beta_{t}\left(\frac{S_{t}}{A_{t-1}}\right)+\beta_{2}\left(\frac{\Delta S_{t}}{A_{t-1}}\right)+\varepsilon_{t}
$$

where $A_{t}$ is the total assetss at the end of period t, $S_{t}$ the sales during period t and $\Delta S_{t}=S_{t}-S_{t-1}$ 
Table 4

\section{Accruals Management of Firms Achieving Current Year's Peer Performance Benchmark}

\begin{tabular}{|c|c|c|c|c|}
\hline \multirow[t]{2}{*}{ Dependent Variable } & \multicolumn{2}{|c|}{$\begin{array}{c}A T A_{i t} \\
\text { Model } 1\end{array}$} & \multicolumn{2}{|c|}{$\begin{array}{c}A C A_{i t} \\
\text { Model } 2\end{array}$} \\
\hline & $\begin{array}{c}\text { Coefficients } \\
0.0575^{* * *}\end{array}$ & $\begin{array}{c}\boldsymbol{p} \text {-value } \\
<.0001\end{array}$ & $\begin{array}{c}\text { Coefficients } \\
0.0661^{* * * *}\end{array}$ & $\begin{array}{l}p \text {-value } \\
<.0001\end{array}$ \\
\hline Achieve $_{t}$ & $0.0055 * * *$ & $<.0001$ & $0.0032 * * *$ & 0.0032 \\
\hline $\log A T_{i t}$ & $-0.0104 * * *$ & $<.0001$ & $-0.0103 * * *$ & $<.0001$ \\
\hline$B M_{i t}$ & $0.0047 * * *$ & $<.0001$ & $0.0033 * * *$ & $<.0001$ \\
\hline$L E V_{i t}$ & $0.0324 * * *$ & $<.0001$ & $0.0192 * * *$ & $<.0001$ \\
\hline$R O A_{i t}$ & $0.2335 * * *$ & $<.0001$ & $0.2086^{* * *}$ & $<.0001$ \\
\hline$A T A_{i t-1}$ or $A C A_{i t-1}$ & $0.0382 * * *$ & $<.0001$ & $0.0163 * * *$ & $<.0001$ \\
\hline Threshold $1_{i t}$ & -0.0002 & 0.9036 & 0.0006 & 0.7267 \\
\hline Threshold $2_{i t}$ & -0.0019 & 0.2076 & $-0.0031 * *$ & 0.0325 \\
\hline Threshold $3_{i t}$ & $-0.0113 * * *$ & $<.0001$ & $-0.00998^{* *}$ & $<.0001$ \\
\hline Year Fixed Effects & \multirow{2}{*}{\multicolumn{2}{|c|}{$\begin{array}{l}\text { Yes } \\
\text { Yes }\end{array}$}} & \multicolumn{2}{|c|}{ Yes } \\
\hline $\begin{array}{l}\text { Industry Fixed } \\
\text { Effects }\end{array}$ & & & & \\
\hline $\mathrm{N}$ & \multicolumn{2}{|c|}{47968} & \multicolumn{2}{|c|}{47968} \\
\hline Adjusted $\mathrm{R}^{2}$ & \multicolumn{2}{|c|}{0.1381} & \multicolumn{2}{|c|}{0.1282} \\
\hline
\end{tabular}

$*, * *, * * *$ denotes significance at $10 \%, 5 \%$ and $1 \%$ level respectively.

$A T A_{i t}$ is abnormal total accruals, which is the firm-specific residuals derived from following equation estimated cross-sectionally for each industry-year combination:

$\frac{T A_{i t}}{A T_{i t-1}}=\varphi_{0}+\varphi_{1}\left(\frac{1}{A T_{i t-1}}\right)+\varphi_{2}\left(\frac{\Delta R E V_{i t}}{A T_{i t-1}}-\frac{\Delta R E C_{i t}}{A T_{i t-1}}\right)+\varphi_{3}\left(\frac{P P E_{i t}}{A T_{i t-1}}\right)+R O A_{t-1}+\varepsilon_{i t}$

$A C A_{i t}$ is abnormal current accruals, which is defined as the firm specific residuals from the following equation estimated cross-sectionally for each year-industry combination.

$\frac{C A_{i t}}{A_{i t-1}}=\varphi_{0}+\varphi_{1}\left(\frac{1}{A_{i t-1}}\right)+\varphi_{2}\left(\frac{\Delta R E V_{i t}}{A_{i t-1}}-\frac{\Delta R E C_{i t}}{A_{i t-1}}\right)+R O A_{t-1}+\varepsilon_{i t}$

Achieve $_{i t}$ is a dummy variable and it equals one if firm $i$ 's current year's performance $\left(R O A_{t}\right)$ is above the peer group by no more than 0.05 . In other words, $R O A_{t}-\operatorname{Peer}\left(R O A_{t}\right)$ is within the range of $(0,0.05)$.

$\operatorname{LogAT} T_{i t}$ is the natural logarithm of total assets of firm $i$ for year $t . \mathrm{BM}_{i t}$ is the book value of equity divided by market value of equity in year $t$ for firm $i . \mathrm{ROA}_{i t}$ is return on assets defined as income before extraordinary items in year $t$ divided by the average of total assets. $L E V_{i t}$ is total liability divided by total assets in year $t$.

Threshold $1_{i t}$ is the indicator variable equal to 1 if the firm avoids losses by a small margin, which is defined as income before extraordinary items scaled by the beginning market value within the range of [0.02]. Threshold $2_{i t}$ is the indicator variable equals to 1 if the firm avoids earnings declines by a small margin, which is defined as change in the income before extraordinary items from year $t-1$ to year $\mathrm{t}$, scaled by the beginning market value within the range of [0.01]. Threshold $3_{i t}$ is an indicator variable equal to 1 if the firm avoids negative earnings surprises by a small margin, which is defined as earnings surprises scaled by beginning price per share within the range of [0.0025]. 
Table 5

\section{Accruals Management of Firms Missing Prior Year's Peer Performance Benchmark}

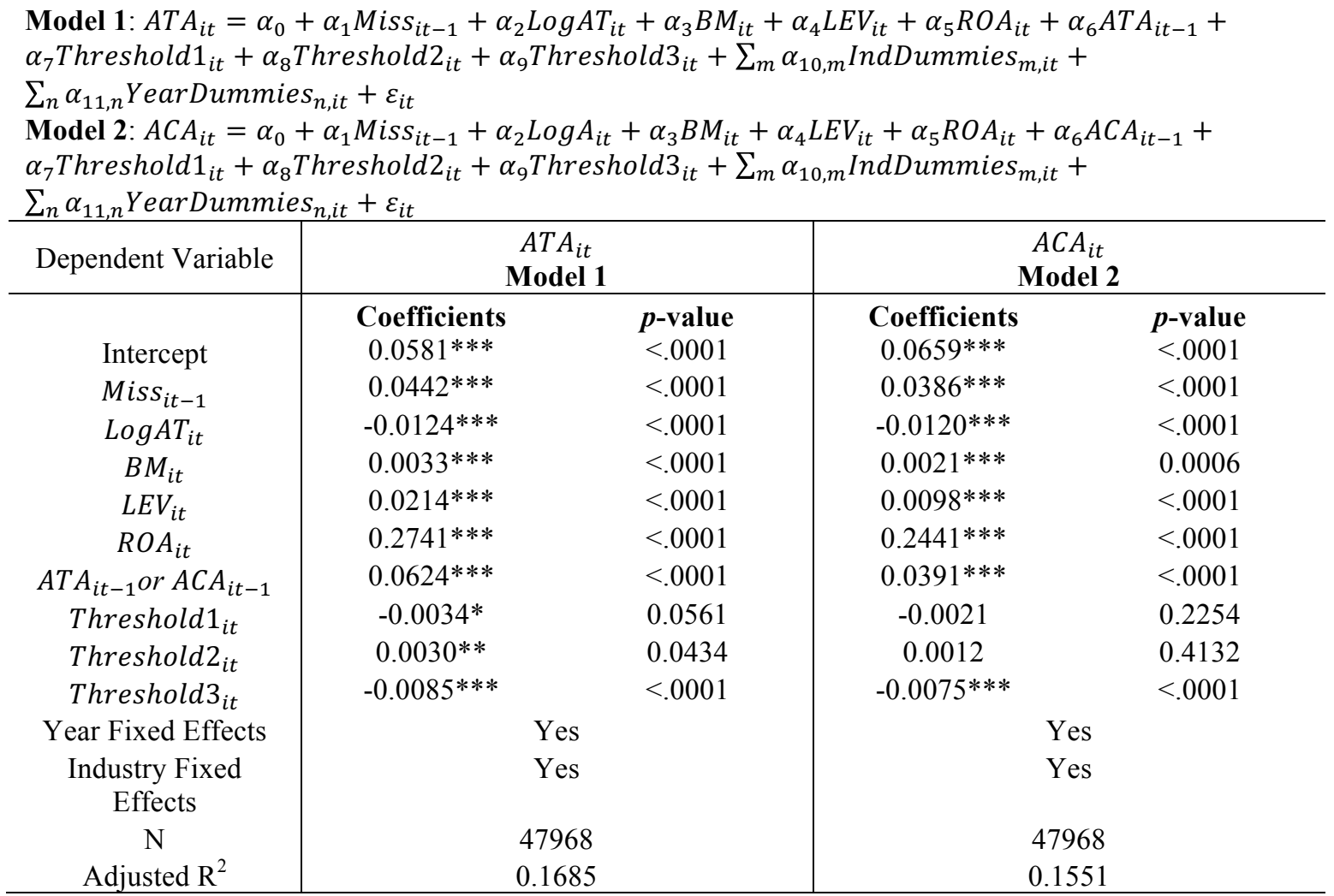

$*, * *, * * *$ denotes significance at $10 \%, 5 \%$ and $1 \%$ level respectively.

$A T A_{i t}$ is abnormal total accruals, which is the firm-specific residuals derived from following equation estimated cross-sectionally for each industry-year combination:

$\frac{T A_{i t}}{A T_{i t-1}}=\varphi_{0}+\varphi_{1}\left(\frac{1}{A T_{i t-1}}\right)+\varphi_{2}\left(\frac{\Delta R E V_{i t}}{A T_{i t-1}}-\frac{\Delta R E C_{i t}}{A T_{i t-1}}\right)+\varphi_{3}\left(\frac{P P E_{i t}}{A T_{i t-1}}\right)+R O A_{t-1}+\varepsilon_{i t}$

$A C A_{i t}$ is abnormal current accruals, which is defined as the firm specific residuals from the following equation estimated cross-sectionally for each year-industry combination.

$\frac{C A_{i t}}{A_{i t-1}}=\varphi_{0}+\varphi_{1}\left(\frac{1}{A_{i t-1}}\right)+\varphi_{2}\left(\frac{\Delta R E V_{i t}}{A_{i t-1}}-\frac{\Delta R E C_{i t}}{A_{i t-1}}\right)+R O A_{t-1}+\varepsilon_{i t}$

Miss $_{i t-1}$ is a dummy variable and it equals one if firm $i$ 's prior year's performance $\left(R O A_{t-1}\right)$ is below that of its peer group.

$\operatorname{LogAT} \mathrm{T}_{i t}$ is the natural logarithm of total assets of firm $i$ for year $t . \mathrm{BM}_{i t}$ is the book value of equity divided by market value of equity in year $t$ for firm $i$. $\mathrm{ROA}_{i t}$ is return on assets defined as income before extraordinary items in year $t$ divided by the average of total assets. $L E V_{i t}$ is total liability divided by total assets in year $t$.

Threshold $1_{i t}$ is the indicator variable equal to 1 if the firm avoids losses by a small margin, which is defined as income before extraordinary items scaled by the beginning market value within the range of [0.02]. Threshold $2_{i t}$ is the indicator variable equals to 1 if the firm avoids earnings declines by a small margin, which is defined as change in the income before extraordinary items from year $t-1$ to year $\mathrm{t}$, scaled by the beginning market value within the range of [0.01]. Threshold $3_{i t}$ is an indicator variable equal to 1 if the firm avoids negative earnings surprises by a small margin, which is defined as earnings surprises scaled by beginning price per share within the range of [0.0025]. 
Table 6

\section{Accruals Management of Firms Missing Prior Year's Peer Performance Benchmark and Achieving Current Year's Peer Performance Benchmark}

\begin{tabular}{|c|c|c|c|c|}
\hline Dependent Variable & \multicolumn{2}{|c|}{$\begin{array}{c}A T A_{i t} \\
\text { Model } 1\end{array}$} & \multicolumn{2}{|c|}{$\begin{array}{c}A C A_{i t} \\
\text { Model } 2\end{array}$} \\
\hline & Coefficients & $p$-value & Coefficients & $p$-value \\
\hline Intercept & $0.0583 * * *$ & $<.0001$ & $0.0663 * * *$ & $<.0001$ \\
\hline Achieve $_{i t}$ & $0.0039 * * *$ & 0.0035 & 0.0014 & 0.2605 \\
\hline UnPerf & 0.0014 & 0.3007 & -0.0008 & 0.5221 \\
\hline $\begin{array}{l}\text { Achieve }_{i t} \\
\text { * UnPerf } \text { Unt-1 }_{\text {it }}\end{array}$ & $0.0068 * * *$ & 0.0090 & $0.0072 * * *$ & 0.0034 \\
\hline $\log A T_{i t}$ & $-0.0105 * * *$ & $<.0001$ & $-0.0103 * * *$ & $<.0001$ \\
\hline$B M_{i t}$ & $0.0047 * * *$ & $<.0001$ & $0.0033 * * *$ & $<.0001$ \\
\hline$L E V_{i t}$ & $0.0320 * * *$ & $<.0001$ & $0.0192 * * *$ & $<.0001$ \\
\hline$R O A_{i t}$ & $0.2337 * * *$ & $<.0001$ & $0.2087 * * *$ & $<.0001$ \\
\hline$A T A_{i t-1}$ or $A C A_{i t-1}$ & $0.0380 * * *$ & $<.0001$ & $0.0164 * * *$ & $<.0001$ \\
\hline Threshold $1_{i t}$ & -0.0002 & 0.9012 & 0.0007 & 0.6717 \\
\hline Threshold $2_{i t}$ & -0.0017 & 0.2702 & $-0.0029 * *$ & 0.0460 \\
\hline Threshold $3_{i t}$ & $-0.0113 * * *$ & $<.0001$ & $-0.0100 * * *$ & $<.0001$ \\
\hline Year Fixed Effects & \multicolumn{2}{|c|}{ Yes } & \multicolumn{2}{|c|}{ Yes } \\
\hline Industry Fixed Effects & \multicolumn{2}{|c|}{ Yes } & \multicolumn{2}{|c|}{ Yes } \\
\hline $\mathrm{N}$ & \multicolumn{2}{|c|}{47968} & \multicolumn{2}{|c|}{47968} \\
\hline Adjusted $\mathrm{R}^{2}$ & \multicolumn{2}{|c|}{0.1383} & \multicolumn{2}{|c|}{0.1284} \\
\hline
\end{tabular}

$* * *, * * *$ denotes significance at $10 \%, 5 \%$ and $1 \%$ level respectively.

$A T A_{i t}$ is abnormal total accruals, which is the firm-specific residuals derived from following equation estimated cross-sectionally for each industry-year combination:

$\frac{T A_{i t}}{A T_{i t-1}}=\varphi_{0}+\varphi_{1}\left(\frac{1}{A T_{i t-1}}\right)+\varphi_{2}\left(\frac{\Delta R E V_{i t}}{A T_{i t-1}}-\frac{\Delta R E C_{i t}}{A T_{i t-1}}\right)+\varphi_{3}\left(\frac{P P E_{i t}}{A T_{i t-1}}\right)+R O A_{t-1}+\varepsilon_{i t}$

$A C A_{i t}$ is abnormal current accruals, which is defined as the firm specific residuals from the following equation estimated cross-sectionally for each year-industry combination.

$\frac{C A_{i t}}{A_{i t-1}}=\varphi_{0}+\varphi_{1}\left(\frac{1}{A_{i t-1}}\right)+\varphi_{2}\left(\frac{\Delta R E V_{i t}}{A_{i t-1}}-\frac{\Delta R E C_{i t}}{A_{i t-1}}\right)+R O A_{t-1}+\varepsilon_{i t}$

$\operatorname{UnPer} f_{i t-1}$ is a dummy variable and it equals one if firm $i$ 's prior year's performance $\left(R O A_{t-1}\right)$ is below that of its peer group by not more than 0.05 . To be more specific, $R O A_{t-1}-\operatorname{Peer}\left(R O A_{t-1}\right)$ is within the range of $(-0.05,0)$.

Achieve $_{i t}$ is a dummy variable and it equals one if firm $i$ 's current year's performance $\left(R O A_{t}\right)$ is above the peer group by no more than 0.05 . In other words, $R O A_{t}-\operatorname{Peer}\left(R O A_{t}\right)$ is within the range of $(0,0.05)$.

Achieve $_{i t} * \operatorname{UnPerf}_{i t-1}$ is the interaction term of Achieve $_{i t}$ and $U n P e r f_{i t-1}$.

$\operatorname{LogAT}_{i t}$ is the natural logarithm of total assets of firm $i$ for year $t . \mathrm{BM}_{i t}$ is the book value of equity divided by market value of equity in year $t$ for firm $i$. $\mathrm{ROA}_{i t}$ is return on assets defined as income before extraordinary items in year $t$ divided by the average of total assets. $L E V_{i t}$ is total liability divided by total assets in year $t$.

Threshold $1_{i t}$ is the indicator variable equal to 1 if the firm avoids losses by a small margin, which is defined as income before extraordinary items scaled by the beginning market value within the range of 
[0.02]. Threshold $2_{i t}$ is the indicator variable equals to 1 if the firm avoids earnings declines by a small margin, which is defined as change in the income before extraordinary items from year $t-1$ to year $\mathrm{t}$, scaled by the beginning market value within the range of [0.01]. Threshold $3_{i t}$ is an indicator variable equal to 1 if the firm avoids negative earnings surprises by a small margin, which is defined as earnings surprises scaled by beginning price per share within the range of [0.0025]. 
Table 7

\section{Real Earnings Management of Firms Achieving Current Year's Peer Performance Benchmark}

\begin{tabular}{|c|c|c|c|c|}
\hline \multirow[t]{2}{*}{ Dependent Variable } & \multicolumn{2}{|c|}{$\begin{array}{c}\text { rmUDISX }_{i t} \\
\text { Model } 1\end{array}$} & \multicolumn{2}{|c|}{$\begin{array}{c}\text { rmCASH }_{i t} \\
\text { Model } 2\end{array}$} \\
\hline & Coefficients & $p$-value & Coefficients & $p$-value \\
\hline Intercept & $0.0373 * * *$ & $<.0001$ & $0.0580 * * *$ & $<.0001$ \\
\hline Achieve $_{i t}$ & -0.0002 & 0.7884 & $-0.0035 * * *$ & 0.0002 \\
\hline $\log A T_{i t}$ & $-0.0073 * * *$ & $<.0001$ & $0.0023 * * *$ & $<.0001$ \\
\hline$B M_{i t}$ & $0.0047 * * *$ & $<.0001$ & $-0.0041 * * *$ & $<.0001$ \\
\hline$L E V_{i t}$ & $0.0437 * * *$ & $<.0001$ & $-0.0361 * * *$ & $<.0001$ \\
\hline$R O A_{i t}$ & $0.1796 * * *$ & $<.0001$ & $0.5960 * * *$ & $<.0001$ \\
\hline Threshold $1_{i t}$ & $-0.0079 * * *$ & $<.0001$ & $0.0025^{*}$ & 0.0854 \\
\hline Threshold $2_{i t}$ & $-0.0039 * * *$ & 0.0001 & 0.0015 & 0.2263 \\
\hline Threshold $3_{i t}$ & -0.0001 & 0.8582 & $0.0046^{* * *}$ & $<.0001$ \\
\hline$A T A_{i t}$ & $-0.5679 * * *$ & $<.0001$ & $-0.6883 * * *$ & $<.0001$ \\
\hline Year Fixed Effects & \multicolumn{2}{|c|}{ Yes } & \multicolumn{2}{|c|}{ Yes } \\
\hline $\begin{array}{c}\text { Industry Fixed } \\
\text { Effects }\end{array}$ & \multicolumn{2}{|c|}{ Yes } & \multicolumn{2}{|c|}{ Yes } \\
\hline $\mathrm{N}$ & \multicolumn{2}{|c|}{46930} & \multicolumn{2}{|c|}{46930} \\
\hline Adjusted $\mathrm{R}^{2}$ & \multicolumn{2}{|c|}{0.4160} & \multicolumn{2}{|c|}{0.6455} \\
\hline
\end{tabular}

$*, * *, * * *$ denotes significance at $10 \%, 5 \%$ and $1 \%$ level respectively.

rmUDISX $_{i t}$ is the unexpected abnormal level of discretionary expenditures estimated following Zang (2012). First, estimate the abnormal level of discretionary expenditures $\left(\mathrm{rmDISX}_{i t}\right)$ as the residuals from the regression below. The regression is estimated cross-sectionally for each year and each two-digit SIC code with at least ten observations.

$\frac{\text { DISX }_{i t}}{A_{i t-1}}=\alpha_{0}+\alpha_{1}\left(\frac{1}{A_{i t-1}}\right)+\alpha_{2}\left(\frac{S_{i t-1}}{A_{i t-1}}\right)+\varepsilon_{i t}$

Second, estimate the unexpected abnormal level of discretionary expenditures $\left(\mathrm{rmUDISX}_{i t}\right)$ as the residuals from the regression below. The regression is estimated cross-sectionally for each industry-year combination.

$$
\begin{gathered}
\operatorname{rmDISX}_{i t}=\beta_{0}+\beta_{1} \text { Market }_{\text {Share }_{i t-1}}+\beta_{2} \text { ZSCORE }_{i t-1}+\beta_{3} \text { TAX }_{\text {Rate }_{i t}}+\beta_{4} \text { BIG }_{i t}+\beta_{5} \text { NOA }_{i t-1} \\
+\beta_{6} \text { CYCLE }_{i t-1} \\
+\beta_{7} \text { ROA }_{i t}+\beta_{8} \text { Log AT }_{i t}+\beta_{9} \text { MtoB }_{i t}+\beta_{10} \text { Earn }_{i t}+\varepsilon_{i t}
\end{gathered}
$$

To be consistent with Zang (2012), the unexpected abnormal level of discretionary expenditures are multiplied by (-1) such that higher values indicate greater amounts of unexpected abnormal level of discretionary expenditures reduced by firms to increase reported earnings.

$\mathrm{rmCASH}_{i t}$ is the abnormal cash flow from operations estimated following Roychowdhury (2006), which is defined as the firm specific residuals from the following equation estimated cross-sectionally for each yearindustry combination.

$$
\frac{C F O_{t}}{A_{t-1}}=\alpha_{0}+\alpha_{1}\left(\frac{1}{A_{t-1}}\right)+\beta_{t}\left(\frac{S_{t}}{A_{t-1}}\right)+\beta_{2}\left(\frac{\Delta S_{t}}{A_{t-1}}\right)+\varepsilon_{t}
$$

where $A_{t}$ is the total assetss at the end of period t, $S_{t}$ the sales during period t and $\Delta S_{t}=S_{t}-S_{t-1}$. 
$A T A_{i t}$ is abnormal total accruals, which is the firm-specific residuals derived from following equation estimated cross-sectionally for each industry-year combination:

$\frac{T A_{i t}}{A T_{i t-1}}=\varphi_{0}+\varphi_{1}\left(\frac{1}{A T_{i t-1}}\right)+\varphi_{2}\left(\frac{\Delta R E V_{i t}}{A T_{i t-1}}-\frac{\Delta R E C_{i t}}{A T_{i t-1}}\right)+\varphi_{3}\left(\frac{P P E_{i t}}{A T_{i t-1}}\right)+R O A_{t-1}+\varepsilon_{i t}$

Achieve $_{i t}$ is a dummy variable and it equals one if firm $i$ 's current year's performance $\left(R O A_{t}\right)$ is above the peer group by no more than 0.05 . In other words, $R O A_{t}-\operatorname{Peer}\left(R O A_{t}\right)$ is within the range of $(0,0.05)$.

$\operatorname{LogAT}_{i t}$ is the natural logarithm of total assets of firm $i$ for year $t . \mathrm{BM}_{i t}$ is the book value of equity divided by market value of equity in year $t$ for firm $i$. $\mathrm{ROA}_{i t}$ is return on assets defined as income before

extraordinary items in year $t$ divided by the average of total assets. $L E V_{i t}$ is total liability divided by total assets in year $t$.

Threshold $1_{i t}$ is the indicator variable equal to 1 if the firm avoids losses by a small margin, which is defined as income before extraordinary items scaled by the beginning market value within the range of [0.02]. Threshold $2_{i t}$ is the indicator variable equals to 1 if the firm avoids earnings declines by a small margin, which is defined as change in the income before extraordinary items from year $t-1$ to year $\mathrm{t}$, scaled by the beginning market value within the range of [0.01]. Threshold $3_{i t}$ is an indicator variable equal to 1 if the firm avoids negative earnings surprises by a small margin, which is defined as earnings surprises scaled by beginning price per share within the range of [0.0025]. 
Table 8

Real Earnings Management of Firms Missing Prior Year's Peer Performance Benchmark

Model 1: rmUDISX $_{i t}=\alpha_{0}+\alpha_{1}$ Miss $_{i t-1}+\alpha_{2} \log _{i t}+\alpha_{3} B M_{i t}+\alpha_{4} L E V_{i t}+\alpha_{5} R O A_{i t}+$

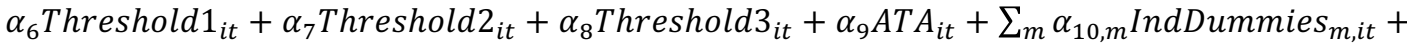
$\sum_{n} \alpha_{11, n}$ YearDummies $_{n, i t}+\varepsilon_{i t}$

Model 2: rmCASH $_{i t}=\alpha_{0}+\alpha_{1}$ Miss $_{i t-1}+\alpha_{2} \operatorname{LogAT} T_{i t}+\alpha_{3} B M_{i t}+\alpha_{4} L E V_{i t}+\alpha_{5} R O A_{i t}+$

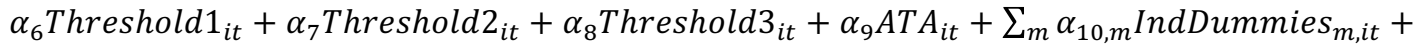
$\sum_{n} \alpha_{11, n}$ YearDummies $_{n, i t}+\varepsilon_{i t}$

\begin{tabular}{|c|c|c|c|c|}
\hline \multirow[t]{2}{*}{ Dependent Variable } & \multicolumn{2}{|c|}{$\begin{array}{c}\text { rmUDISX }_{i t} \\
\text { Model } 1\end{array}$} & \multicolumn{2}{|c|}{$\begin{array}{c}\text { rmCASH }_{i t} \\
\text { Model } 2\end{array}$} \\
\hline & Coefficients & $p$-value & Coefficients & $p$-value \\
\hline Intercept & $0.0360 * * *$ & $<.0001$ & $0.0684 * * *$ & $<.0001$ \\
\hline $\operatorname{Miss}_{i t-1}$ & $0.0062 * * *$ & $<.0001$ & $0.0136 * * *$ & $<.0001$ \\
\hline $\log A T_{i t}$ & $-0.0071 * * *$ & $<.0001$ & $0.0017 * * *$ & $<.0001$ \\
\hline$B M_{i t}$ & $0.0043 * * *$ & $<.0001$ & $-0.0064 * * *$ & $<.0001$ \\
\hline$L E V_{i t}$ & $0.0401 * * *$ & $<.0001$ & $-0.0531 * * *$ & $<.0001$ \\
\hline$R O A_{i t}$ & $0.1555 * * *$ & $<.0001$ & $0.6055^{* * * *}$ & $<.0001$ \\
\hline Threshold $1_{i t}$ & $-0.0092 * * *$ & $<.0001$ & $0.0031 *$ & 0.0545 \\
\hline Threshold $2_{i t}$ & $-0.0048 * * *$ & $<.0001$ & 0.0004 & 0.7487 \\
\hline Threshold $3_{i t}$ & -0.0005 & 0.5416 & $0.0052 * * *$ & $<.0001$ \\
\hline$A T A_{i t}$ & $-0.5954 * * *$ & $<.0001$ & $-0.7010 * * *$ & $<.0001$ \\
\hline Year Fixed Effects & \multicolumn{2}{|c|}{ Yes } & \multicolumn{2}{|c|}{ Yes } \\
\hline $\begin{array}{c}\text { Industry Fixed } \\
\text { Effects }\end{array}$ & \multicolumn{2}{|c|}{ Yes } & \multicolumn{2}{|c|}{ Yes } \\
\hline $\mathrm{N}$ & \multicolumn{2}{|c|}{46930} & \multicolumn{2}{|c|}{46930} \\
\hline Adjusted $\mathrm{R}^{2}$ & \multicolumn{2}{|c|}{0.3867} & \multicolumn{2}{|c|}{0.6015} \\
\hline
\end{tabular}

$*, * *, * * *$ denotes significance at $10 \%, 5 \%$ and $1 \%$ level respectively.

rmUDISX $_{i t}$ is the unexpected abnormal level of discretionary expenditures estimated following Zang (2012). First, estimate the abnormal level of discretionary expenditures $\left(\mathrm{rmDISX}_{i t}\right)$ as the residuals from the regression below. The regression is estimated cross-sectionally for each year and each two-digit SIC code with at least ten observations.

$\frac{\operatorname{DISX}_{i t}}{A_{i t-1}}=\alpha_{0}+\alpha_{1}\left(\frac{1}{A_{i t-1}}\right)+\alpha_{2}\left(\frac{S_{i t-1}}{A_{i t-1}}\right)+\varepsilon_{i t}$

Second, estimate the unexpected abnormal level of discretionary expenditures $\left(\right.$ rmUDISX $\left._{i t}\right)$ as the residuals from the regression below. The regression is estimated cross-sectionally for each industry-year combination.

$$
\begin{aligned}
& \operatorname{rmDISX}_{i t}=\beta_{0}+\beta_{1} \text { Market }_{\text {Share }_{i t-1}}+\beta_{2} \text { ZSCORE }_{i t-1}+\beta_{3} \text { TAX }_{\text {Rate }_{i t}}+\beta_{4} \text { BIG }_{i t}+\beta_{5} N O A_{i t-1} \\
& +\beta_{6} C Y C L E_{i t-1}
\end{aligned}
$$

To be consistent with Zang (2012), the unexpected abnormal level of discretionary expenditures are multiplied by (-1) such that higher values indicate greater amounts of unexpected abnormal level of discretionary expenditures reduced by firms to increase reported earnings.

$\mathrm{rmCASH}_{i t}$ is the abnormal cash flow from operations estimated following Roychowdhury (2006), which is defined as the firm specific residuals from the following equation estimated cross-sectionally for each yearindustry combination.

$$
\frac{C F O_{t}}{A_{t-1}}=\alpha_{0}+\alpha_{1}\left(\frac{1}{A_{t-1}}\right)+\beta_{t}\left(\frac{S_{t}}{A_{t-1}}\right)+\beta_{2}\left(\frac{\Delta S_{t}}{A_{t-1}}\right)+\varepsilon_{t}
$$

where $A_{t}$ is the total assetss at the end of period t, $S_{t}$ the sales during period t and $\Delta S_{t}=S_{t}-S_{t-1}$. 
$A T A_{i t}$ is abnormal total accruals, which is the firm-specific residuals derived from following equation estimated cross-sectionally for each industry-year combination:

$\frac{T A_{i t}}{A T_{i t-1}}=\varphi_{0}+\varphi_{1}\left(\frac{1}{A T_{i t-1}}\right)+\varphi_{2}\left(\frac{\Delta R E V_{i t}}{A T_{i t-1}}-\frac{\Delta R E C_{i t}}{A T_{i t-1}}\right)+\varphi_{3}\left(\frac{P P E_{i t}}{A T_{i t-1}}\right)+R O A_{t-1}+\varepsilon_{i t}$

Miss $_{i t-1}$ is a dummy variable and it equals one if firm $i$ 's prior year's performance $\left(R O A_{t-1}\right)$ is below that of its peer group.

$\operatorname{LogAT}_{i t}$ is the natural logarithm of total assets of firm $i$ for year $t . \mathrm{BM}_{i t}$ is the book value of equity divided by market value of equity in year $t$ for firm $i$. $\mathrm{ROA}_{i t}$ is return on assets defined as income before

extraordinary items in year $t$ divided by the average of total assets. $L E V_{i t}$ is total liability divided by total

assets in year $t$.

Threshold $1_{i t}$ is the indicator variable equal to 1 if the firm avoids losses by a small margin, which is defined as income before extraordinary items scaled by the beginning market value within the range of [0.02]. Threshold $2_{i t}$ is the indicator variable equals to 1 if the firm avoids earnings declines by a small margin, which is defined as change in the income before extraordinary items from year $t-1$ to year $t$, scaled by the beginning market value within the range of [0.01]. Threshold $3_{i t}$ is an indicator variable equal to 1 if the firm avoids negative earnings surprises by a small margin, which is defined as earnings surprises scaled by beginning price per share within the range of [0.0025].

Table 9 


\section{Real Earnings Management of Firms Missing Prior Year's Peer Performance Benchmark and Achieving Current year's Peer Performance Benchmark}

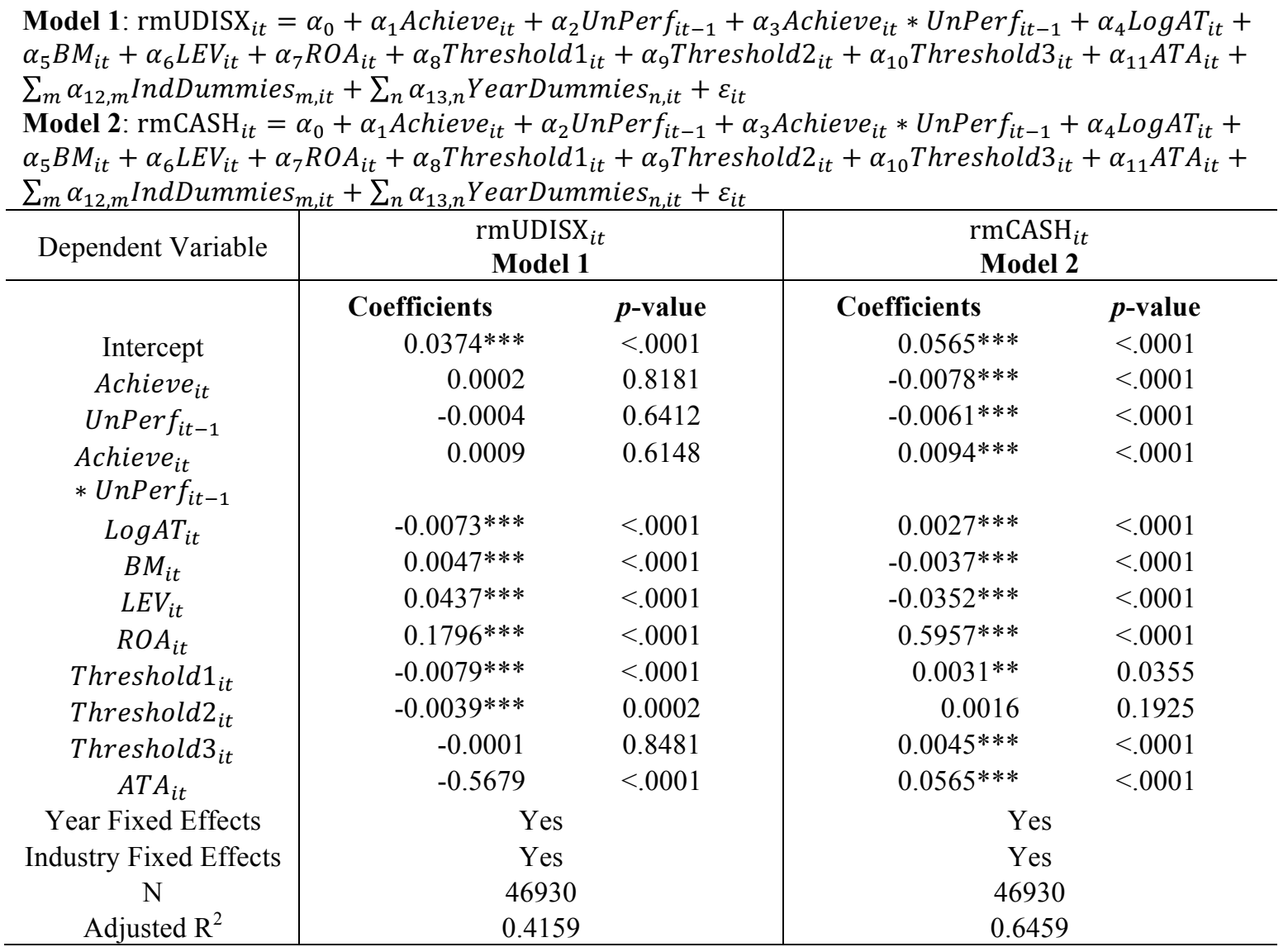

$*, * * * * *$ denotes significance at $10 \%, 5 \%$ and $1 \%$ level respectively.

rmUDISX $_{i t}$ is the unexpected abnormal level of discretionary expenditures estimated following Zang (2012). First, estimate the abnormal level of discretionary expenditures $\left(\mathrm{rmDISX}_{i t}\right)$ as the residuals from the regression below. The regression is estimated cross-sectionally for each year and each two-digit SIC code with at least ten observations.

$\frac{\text { DISX }_{i t}}{A_{i t-1}}=\alpha_{0}+\alpha_{1}\left(\frac{1}{A_{i t-1}}\right)+\alpha_{2}\left(\frac{S_{i t-1}}{A_{i t-1}}\right)+\varepsilon_{i t}$

Second, estimate the unexpected abnormal level of discretionary expenditures ( rmUDISX $_{i t}$ ) as the residuals from the regression below. The regression is estimated cross-sectionally for each industry-year combination.

$$
\begin{gathered}
\operatorname{rmDISX}_{i t}=\beta_{0}+\beta_{1} \text { Market }_{\text {Share }_{i t-1}}+\beta_{2} \text { ZSCORE }_{i t-1}+\beta_{3} \text { TAX }_{\text {Rate }_{i t}}+\beta_{4} \text { BIG }_{i t}+\beta_{5} \text { NOA }_{i t-1} \\
+\beta_{6} \text { CYCLE }_{i t-1} \\
+\beta_{7} \text { ROA }_{i t}+\beta_{8} \text { LogAT }_{i t}+\beta_{9} \text { Mto }_{i t}+\beta_{10} \text { Earn }_{i t}+\varepsilon_{i t}
\end{gathered}
$$

To be consistent with Zang (2012), the unexpected abnormal level of discretionary expenditures are multiplied by $(-1)$ such that higher values indicate greater amounts of unexpected abnormal level of discretionary expenditures reduced by firms to increase reported earnings.

$\mathrm{rmCASH}_{i t}$ is the abnormal cash flow from operations estimated following Roychowdhury (2006), which is defined as the firm specific residuals from the following equation estimated cross-sectionally for each yearindustry combination.

$$
\frac{C F O_{t}}{A_{t-1}}=\alpha_{0}+\alpha_{1}\left(\frac{1}{A_{t-1}}\right)+\beta_{t}\left(\frac{S_{t}}{A_{t-1}}\right)+\beta_{2}\left(\frac{\Delta S_{t}}{A_{t-1}}\right)+\varepsilon_{t}
$$


where $A_{t}$ is the total assetss at the end of period t, $S_{t}$ the sales during period t and $\Delta S_{t}=S_{t}-S_{t-1}$. $A T A_{i t}$ is abnormal total accruals, which is the firm-specific residuals derived from following equation estimated cross-sectionally for each industry-year combination:

$\frac{T A_{i t}}{A T_{i t-1}}=\varphi_{0}+\varphi_{1}\left(\frac{1}{A T_{i t-1}}\right)+\varphi_{2}\left(\frac{\Delta R E V_{i t}}{A T_{i t-1}}-\frac{\Delta R E C_{i t}}{A T_{i t-1}}\right)+\varphi_{3}\left(\frac{P P E_{i t}}{A T_{i t-1}}\right)+R O A_{t-1}+\varepsilon_{i t}$

$\operatorname{UnPerf} f_{i t-1}$ is a dummy variable and it equals one if firm $i$ 's prior year's performance $\left(R O A_{t-1}\right)$ is below that of its peer group by no more than 0.05 . In other words, $R O A_{t-1}-\operatorname{Peer}\left(R O A_{t-1}\right)$ is within the range of $(-0.05,0)$.

Achieve $_{i t}$ is a dummy variable and it equals one if firm $i$ 's current year's performance $\left(R O A_{t}\right)$ is above the peer group by no more than 0.05 . In other words, $R O A_{t}-\operatorname{Peer}\left(R O A_{t}\right)$ is within the range of $(0,0.05)$.

Achieve $_{i t} * \operatorname{UnPerf}_{i t-1}$ is the interaction term of Achieve $_{i t}$ and $U n P e r f_{i t-1}$.

$\operatorname{LogAT} \mathrm{T}_{i t}$ is the natural logarithm of total assets of firm $i$ for year $t . \mathrm{BM}_{i t}$ is the book value of equity divided by market value of equity in year $t$ for firm $i$. $\mathrm{ROA}_{i t}$ is return on assets defined as income before

extraordinary items in year $t$ divided by the average of total assets. $L E V_{i t}$ is total liability divided by total assets in year $t$.

Threshold $1_{i t}$ is the indicator variable equal to 1 if the firm avoids losses by a small margin, which is defined as income before extraordinary items scaled by the beginning market value within the range of [0.02]. Threshold $2_{i t}$ is the indicator variable equals to 1 if the firm avoids earnings declines by a small margin, which is defined as change in the income before extraordinary items from year $t-1$ to year $\mathrm{t}$, scaled by the beginning market value within the range of [0.01]. Threshold $3_{i t}$ is an indicator variable equal to 1 if the firm avoids negative earnings surprises by a small margin, which is defined as earnings surprises scaled by beginning price per share within the range of [0.0025].

Table 10

Accruals Management of Firms Missing Prior Two Year's Mean Peer Performance Benchmark 


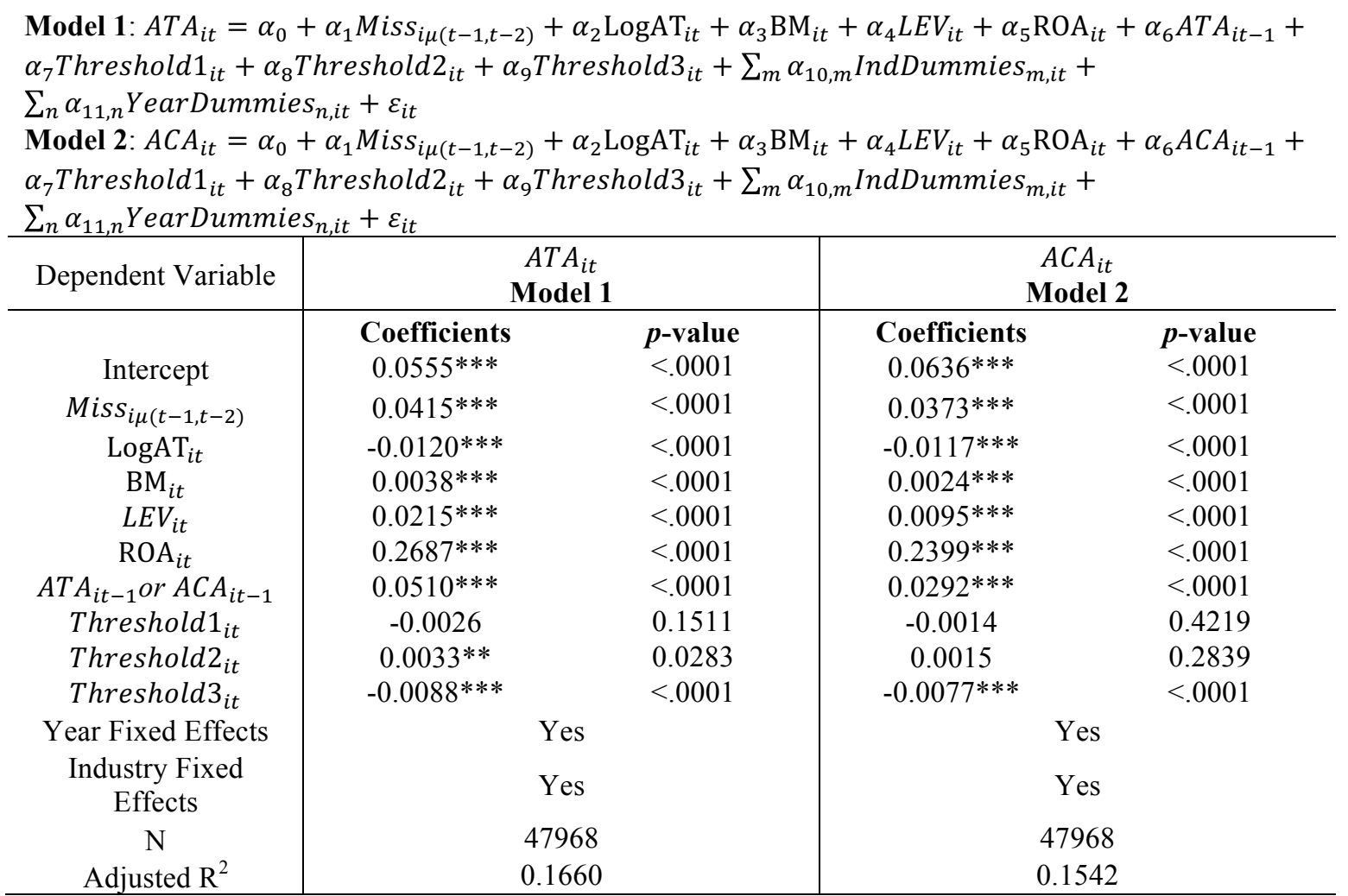

$*, * *, * * *$ denotes significance at $10 \%, 5 \%$ and $1 \%$ level respectively.

$A T A_{i t}$ is abnormal total accruals, which is the firm-specific residuals derived from following equation estimated cross-sectionally for each industry-year combination:

$\frac{T A_{i t}}{A T_{i t-1}}=\varphi_{0}+\varphi_{1}\left(\frac{1}{A T_{i t-1}}\right)+\varphi_{2}\left(\frac{\Delta R E V_{i t}}{A T_{i t-1}}-\frac{\Delta R E C_{i t}}{A T_{i t-1}}\right)+\varphi_{3}\left(\frac{P P E_{i t}}{A T_{i t-1}}\right)+R O A_{t-1}+\varepsilon_{i t}$

$A C A_{i t}$ is abnormal current accruals, which is defined as the firm specific residuals from the following equation estimated cross-sectionally for each year-industry combination.

$\frac{C A_{i t}}{A T_{i t-1}}=\varphi_{0}+\varphi_{1}\left(\frac{1}{A T_{i t-1}}\right)+\varphi_{2}\left(\frac{\Delta R E V_{i t}}{A T_{i t-1}}-\frac{\Delta R E C_{i t}}{A T_{i t-1}}\right)+R O A_{t-1}+\varepsilon_{i t}$

Miss $_{i \mu(t-1, t-2)}$ is a dummy variable and it equals one if firm $i$ 's average performance $\left(R O A_{\mu(t-1, t-2)}\right)$ of the past two years is below that of its peer group. $R O A_{\mu(t-1, t-2)}$ is calculated using $\frac{R O A_{t-2}+R O A_{t-1}}{2}$.

$\operatorname{LogAT} i t$ is the natural logarithm of total assets of firm $i$ for year $t . \mathrm{BM}_{i t}$ is the book value of equity divided by market value of equity in year $t$ for firm $i$. $\mathrm{ROA}_{i t}$ is return on assets defined as income before extraordinary items in year $t$ divided by the average of total assets. $L E V_{i t}$ is total liability divided by total assets in year $t$.

Threshold $1_{i t}$ is the indicator variable equal to 1 if the firm avoids losses by a small margin, which is defined as income before extraordinary items scaled by the beginning market value within the range of [0.02]. Threshold $2_{i t}$ is the indicator variable equals to 1 if the firm avoids earnings declines by a small margin, which is defined as change in the income before extraordinary items from year $t-1$ to year $\mathrm{t}$, scaled by the beginning market value within the range of [0.01]. Threshold $3_{i t}$ is an indicator variable equal to 1 if the firm avoids negative earnings surprises by a small margin, which is defined as earnings surprises scaled by beginning price per share within the range of [0.0025].

Table 11 


\section{Accruals Management of Firms Missing Prior Two Year's Mean Peer Performance Benchmark and Achieving Current Year's Peer Performance Benchmark}

\begin{tabular}{|c|c|c|c|c|}
\hline Dependent Variable & \multicolumn{2}{|c|}{$\begin{array}{c}A T A_{i t} \\
\text { Model } 1\end{array}$} & \multicolumn{2}{|c|}{$\begin{array}{c}A C A_{i t} \\
\text { Model } 2\end{array}$} \\
\hline & Coefficients & $p$-value & Coefficients & $p$-value \\
\hline Intercept & $0.0586^{* * *}$ & $<.0001$ & $0.0665^{* * *}$ & $<.0001$ \\
\hline Achieve $_{i t}$ & $0.0031 * *$ & 0.0196 & 0.0007 & 0.5606 \\
\hline $\operatorname{UnPerf}_{i \mu(t-1, t-2)}$ & 0.0011 & 0.4017 & -0.0014 & 0.2588 \\
\hline $\begin{array}{l}\text { Achieve }_{i t} \\
* \operatorname{UnPerf}_{i \mu(t-1, t-2)}\end{array}$ & $0.0097 * * *$ & 0.0002 & $0.0097 * * *$ & $<.0001$ \\
\hline $\operatorname{LogAT}_{i t}$ & $-0.0105^{* * *}$ & $<.0001$ & $-0.0103 * * *$ & $<.0001$ \\
\hline $\mathrm{BM}_{i t}$ & $0.0047 * * *$ & $<.0001$ & $0.0033 * * *$ & $<.0001$ \\
\hline$L E V_{i t}$ & $0.0319 * * *$ & $<.0001$ & $0.0191 * * *$ & $<.0001$ \\
\hline $\mathrm{ROA}_{i t}$ & $0.2337 * * *$ & $<.0001$ & $0.2087 * * *$ & $<.0001$ \\
\hline$A T A_{i t-1}$ or $A C A_{i t-1}$ & $0.0381 * * *$ & $<.0001$ & $0.0165 * * *$ & $<.0001$ \\
\hline Threshold $1_{i t}$ & -0.0001 & 0.9686 & 0.0009 & 0.6217 \\
\hline Threshold $2_{i t}$ & -0.0017 & 0.2797 & $-0.0029 * *$ & 0.0458 \\
\hline Threshold $3_{i t}$ & $-0.0114 * * *$ & $<.0001$ & $-0.0100 * * *$ & $<.0001$ \\
\hline Year Fixed Effects & \multicolumn{2}{|c|}{ Yes } & \multicolumn{2}{|c|}{ Yes } \\
\hline Industry Fixed Effects & & & \multicolumn{2}{|c|}{ Yes } \\
\hline $\mathrm{N}$ & \multicolumn{2}{|c|}{$\begin{array}{l}\text { Yes } \\
47968\end{array}$} & \multirow{2}{*}{\multicolumn{2}{|c|}{$\begin{array}{l}47968 \\
0.1285\end{array}$}} \\
\hline Adjusted $\mathrm{R}^{2}$ & \multicolumn{2}{|c|}{0.1385} & & \\
\hline
\end{tabular}

$*, * *, * * *$ denotes significance at $10 \%, 5 \%$ and $1 \%$ level respectively.

$A T A_{i t}$ is abnormal total accruals, which is the firm-specific residuals derived from following equation estimated cross-sectionally for each industry-year combination:

$\frac{T A_{i t}}{A T_{i t-1}}=\varphi_{0}+\varphi_{1}\left(\frac{1}{A T_{i t-1}}\right)+\varphi_{2}\left(\frac{\Delta R E V_{i t}}{A T_{i t-1}}-\frac{\Delta R E C_{i t}}{A T_{i t-1}}\right)+\varphi_{3}\left(\frac{P P E_{i t}}{A T_{i t-1}}\right)+R O A_{t-1}+\varepsilon_{i t}$

$A C A_{i t}$ is abnormal current accruals, which is defined as the firm specific residuals from the following equation estimated cross-sectionally for each year-industry combination.

$\frac{C A_{i t}}{A T_{i t-1}}=\varphi_{0}+\varphi_{1}\left(\frac{1}{A T_{i t-1}}\right)+\varphi_{2}\left(\frac{\Delta R E V_{i t}}{A T_{i t-1}}-\frac{\Delta R E C_{i t}}{A T_{i t-1}}\right)+R O A_{t-1}+\varepsilon_{i t}$

$\operatorname{UnPerf}_{i \mu(t-1, t-2)}$ is a dummy variable and it equals one if firm $i$ 's average performance $\left(R O A_{\mu(t-1, t-2)}\right)$ of the past two years is below that of its peer group by no more than 0.05 . In other words, $R O A_{\mu(t-1, t-2)}-$ $\operatorname{Peer}\left(R O A_{\mu(t-1, t-2)}\right)$ is within the range of $(-0.05,0) . R O A_{\mu(t-1, t-2)}$ is calculated using $\frac{R O A_{t-2}+R O A_{t-1}}{2}$.

Achieve $_{i t}$ is a dummy variable and it equals one if firm $i$ 's current year's performance $\left(R O A_{t}\right)$ is above the peer group by no more than 0.05 . In other words, $R O A_{t}-\operatorname{Peer}\left(R O A_{t}\right)$ is within the range of $(0,0.05)$.

Achieve $_{i t} * \operatorname{UnPerf}_{i \mu(t-1, t-2)}$ is the interaction term of Achieve $_{i t}$ and $\operatorname{UnPerf}_{i \mu(t-1, t-2)}$.

$\operatorname{LogAT} T_{i t}$ is the natural logarithm of total assets of firm $i$ for year $t . \mathrm{BM}_{i t}$ is the book value of equity divided by market value of equity in year $t$ for firm $i$. $\mathrm{ROA}_{i t}$ is return on assets defined as income before

extraordinary items in year $t$ divided by the average of total assets. $L E V_{i t}$ is total liability divided by total assets in year $t$.

Threshold $1_{i t}$ is the indicator variable equal to 1 if the firm avoids losses by a small margin, which is defined as income before extraordinary items scaled by the beginning market value within the range of [0.02]. Threshold $2_{i t}$ is the indicator variable equals to 1 if the firm avoids earnings declines by a small 
margin, which is defined as change in the income before extraordinary items from year $t-1$ to year $\mathrm{t}$, scaled by the beginning market value within the range of [0.01]. Threshold $3_{i t}$ is an indicator variable equal to 1 if the firm avoids negative earnings surprises by a small margin, which is defined as earnings surprises scaled by beginning price per share within the range of [0.0025].

Table 12

Real Earnings Management of Firms Missing Prior Two Year's Mean Peer Performance Benchmark 


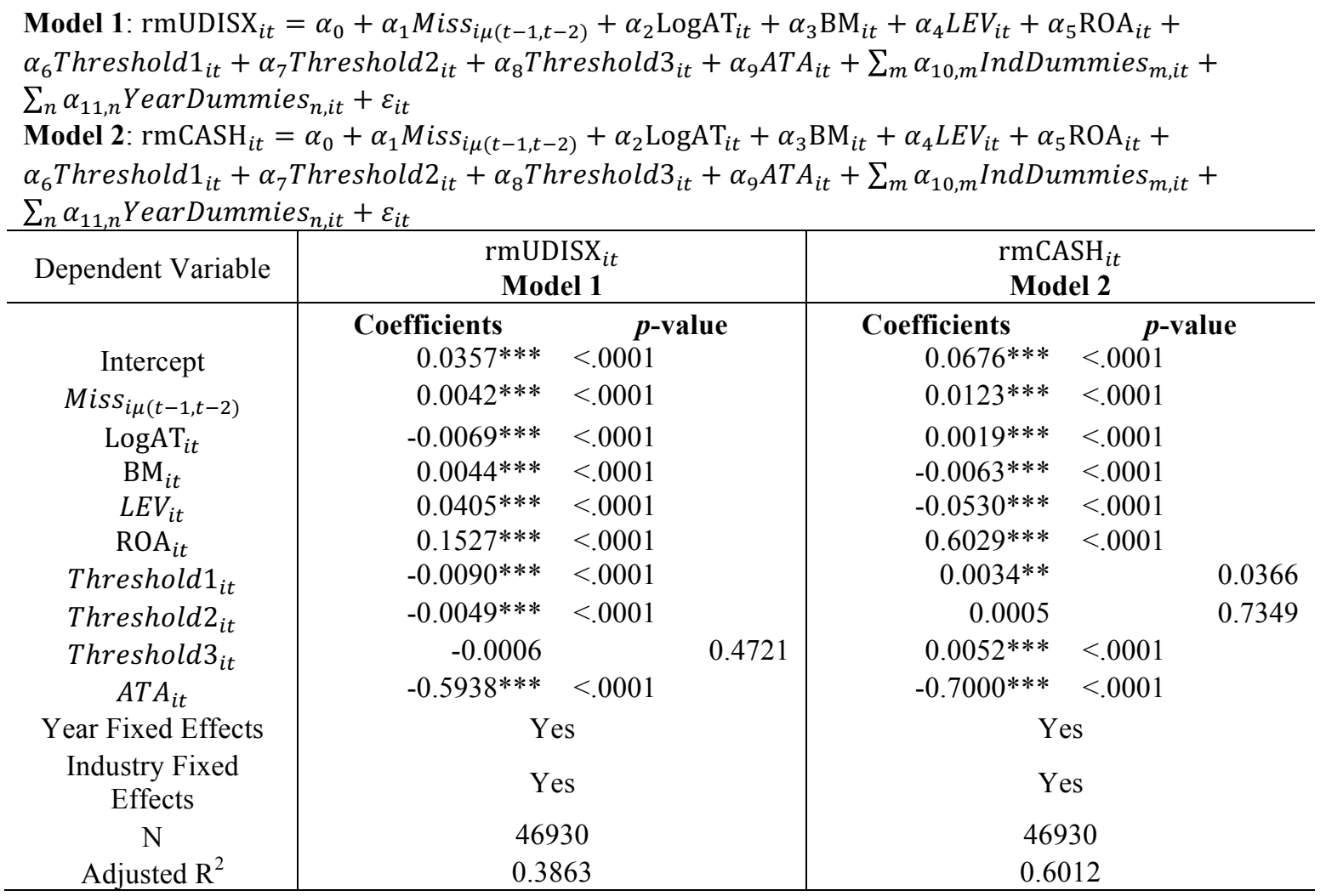

$*, * *, * * *$ denotes significance at $10 \%, 5 \%$ and $1 \%$ level respectively.

rmUDISX $_{i t}$ is the unexpected abnormal level of discretionary expenditures estimated following Zang (2012). First, estimate the abnormal level of discretionary expenditures $\left(\right.$ rmDISX $\left._{i t}\right)$ as the residuals from the regression below. The regression is estimated cross-sectionally for each year and each two-digit SIC code with at least ten observations.

$\frac{\operatorname{DISX}_{i t}}{A_{i t-1}}=\alpha_{0}+\alpha_{1}\left(\frac{1}{A_{i t-1}}\right)+\alpha_{2}\left(\frac{S_{i t-1}}{A_{i t-1}}\right)+\varepsilon_{i t}$

Second, estimate the unexpected abnormal level of discretionary expenditures $\left(\operatorname{rmUDISX}_{i t}\right)$ as the residuals from the regression below. The regression is estimated cross-sectionally for each industry-year combination.

$$
\begin{gathered}
\operatorname{rmDISX}_{i t}=\beta_{0}+\beta_{1} \text { Market }_{\text {Share }_{i t-1}}+\beta_{2} \text { ZSCORE }_{i t-1}+\beta_{3} \text { TAX }_{\text {Rate }}+\beta_{i t}+\beta_{4} \text { BIG }_{i t}+\beta_{5} \text { NOA }_{i t-1} \\
+\beta_{6} \text { CYCLE }_{i t-1} \\
+\beta_{7} \text { ROA }_{i t}+\beta_{8} \operatorname{LogAT}_{i t}+\beta_{9} \text { MtoB }_{i t}+\beta_{10} \text { Earn }_{i t}+\varepsilon_{i t}
\end{gathered}
$$

To be consistent with Zang (2012), the unexpected abnormal level of discretionary expenditures are multiplied by (-1) such that higher values indicate greater amounts of unexpected abnormal level of discretionary expenditures reduced by firms to increase reported earnings.

$\mathrm{rmCASH}_{i t}$ is the abnormal cash flow from operations estimated following Roychowdhury (2006), which is defined as the firm specific residuals from the following equation estimated cross-sectionally for each yearindustry combination.

$$
\frac{C F O_{t}}{A_{t-1}}=\alpha_{0}+\alpha_{1}\left(\frac{1}{A_{t-1}}\right)+\beta_{t}\left(\frac{S_{t}}{A_{t-1}}\right)+\beta_{2}\left(\frac{\Delta S_{t}}{A_{t-1}}\right)+\varepsilon_{t}
$$

where $A_{t}$ is the total assetss at the end of period t, $S_{t}$ the sales during period t and $\Delta S_{t}=S_{t}-S_{t-1}$. $A T A_{i t}$ is abnormal total accruals, which is the firm-specific residuals derived from following equation estimated cross-sectionally for each industry-year combination:

$$
\frac{T A_{i t}}{A T_{i t-1}}=\varphi_{0}+\varphi_{1}\left(\frac{1}{A T_{i t-1}}\right)+\varphi_{2}\left(\frac{\Delta R E V_{i t}}{A T_{i t-1}}-\frac{\Delta R E C_{i t}}{A T_{i t-1}}\right)+\varphi_{3}\left(\frac{P P E_{i t}}{A T_{i t-1}}\right)+R O A_{t-1}+\varepsilon_{i t}
$$


$\operatorname{Miss}_{i \mu(t-1, t-2)}$ is a dummy variable and it equals one if firm $i$ 's average performance $\left(R O A_{\mu(t-1, t-2)}\right)$ of the past two years is below that of its peer group. $R O A_{\mu(t-1, t-2)}$ is calculated using $\frac{R O A_{t-2}+R O A_{t-1}}{2}$. $\operatorname{LogAT}_{i t}$ is the natural logarithm of total assets of firm $i$ for year $t . \mathrm{BM}_{i t}$ is the book value of equity divided by market value of equity in year $t$ for firm $i$. ROA $i t$ is return on assets defined as income before extraordinary items in year $t$ divided by the average of total assets. $L E V_{i t}$ is total liability divided by total assets in year $t$.

Threshold $1_{i t}$ is the indicator variable equal to 1 if the firm avoids losses by a small margin, which is defined as income before extraordinary items scaled by the beginning market value within the range of [0.02]. Threshold $2_{i t}$ is the indicator variable equals to 1 if the firm avoids earnings declines by a small margin, which is defined as change in the income before extraordinary items from year $t-1$ to year $\mathrm{t}$, scaled by the beginning market value within the range of [0.01]. Threshold $3_{i t}$ is an indicator variable equal to 1 if the firm avoids negative earnings surprises by a small margin, which is defined as earnings surprises scaled by beginning price per share within the range of [0.0025].

Table 13

Real Earnings Management of Firms Missing Prior Two Year's Mean Peer Performance Benchmark and Achieving Current Year's Peer Performance Benchmark 


\begin{tabular}{|c|c|c|c|c|}
\hline Dependent Variable & \multicolumn{2}{|c|}{$\begin{array}{c}\text { rmUDISX }_{i t} \\
\text { Model } 1\end{array}$} & \multicolumn{2}{|c|}{$\begin{array}{c}\text { rmCASH }_{i t} \\
\text { Model } 2\end{array}$} \\
\hline Intercept & $\begin{array}{l}\text { Coefficients } \\
0.0380^{* * *}\end{array}$ & $\begin{array}{c}p \text {-value } \\
<.0001\end{array}$ & $\begin{array}{l}\text { Coefficients } \\
0.0575^{* * *}\end{array}$ & $\begin{array}{c}\boldsymbol{p} \text {-value } \\
<.0001\end{array}$ \\
\hline Achieve $_{i t}$ & -0.0002 & 0.8110 & $-0.0048 * * *$ & $<.0001$ \\
\hline $\operatorname{UnPerf}_{i \mu(t-1, t-2)}$ & $0.0029 * * *$ & 0.0012 & $-0.0037 * * *$ & 0.0007 \\
\hline $\begin{array}{l}\text { Achieve }_{i t} \\
* \operatorname{UnPerf}_{i \mu(t-1, t-2)}\end{array}$ & 0.0003 & 0.8574 & $0.0048 * *$ & 0.0207 \\
\hline $\operatorname{LogAT}_{i t}$ & $-0.0075 * * *$ & $<.0001$ & $0.0025 * * *$ & $<.0001$ \\
\hline $\mathrm{BM}_{i t}$ & $0.0046 * * *$ & $<.0001$ & $-0.0039 * * *$ & $<.0001$ \\
\hline$L E V_{i t}$ & $0.0433 * * *$ & $<.0001$ & $-0.0357 * * *$ & $<.0001$ \\
\hline $\mathrm{ROA}_{i t}$ & $0.1798 * * *$ & $<.0001$ & $0.5959 * * *$ & $<.0001$ \\
\hline Threshold $1_{i t}$ & $-0.0080 * * *$ & $<.0001$ & $0.0028 * *$ & 0.0607 \\
\hline Threshold $2_{i t}$ & $-0.0038 * * *$ & 0.0002 & 0.0015 & 0.2228 \\
\hline Threshold $3_{i t}$ & -0.0001 & 0.8477 & $0.0046^{* * *}$ & $<.0001$ \\
\hline$A T A_{i t}$ & $-0.5681 * * *$ & $<.0001$ & $-0.6883 * * *$ & $<.0001$ \\
\hline Year Fixed Effects & Y & & & \\
\hline Industry Fixed Effects & $\mathrm{Y}$ & & & \\
\hline $\mathrm{N}$ & 46 & & & \\
\hline Adjusted $\mathrm{R}^{2}$ & 0.4 & & & \\
\hline
\end{tabular}

$*, * *, * * *$ denotes significance at $10 \%, 5 \%$ and $1 \%$ level respectively.

rmUDISX $_{i t}$ is the unexpected abnormal level of discretionary expenditures estimated following Zang (2012). First, estimate the abnormal level of discretionary expenditures $\left(\right.$ rmDISX $\left._{i t}\right)$ as the residuals from the regression below. The regression is estimated cross-sectionally for each year and each two-digit SIC code with at least ten observations.

$\frac{\text { DISX }_{i t}}{A_{i t-1}}=\alpha_{0}+\alpha_{1}\left(\frac{1}{A_{i t-1}}\right)+\alpha_{2}\left(\frac{S_{i t-1}}{A_{i t-1}}\right)+\varepsilon_{i t}$

Second, estimate the unexpected abnormal level of discretionary expenditures $\left(\operatorname{rmUDISX}_{i t}\right)$ as the residuals from the regression below. The regression is estimated cross-sectionally for each industry-year combination.

$$
\begin{gathered}
\operatorname{rmDISX}_{i t}=\beta_{0}+\beta_{1} \text { Market }_{\text {Share }_{i t-1}}+\beta_{2} \text { ZSCORE }_{i t-1}+\beta_{3} \text { TAX }_{\text {Rate }_{i t}}+\beta_{4} \text { BIG }_{i t}+\beta_{5} \text { NOA A }_{i t-1} \\
+\beta_{6} \text { CYCLE }_{i t-1} \\
+\beta_{7} \text { ROA }_{i t}+\beta_{8} \operatorname{LogAT}_{i t}+\beta_{9} \text { MtoB }_{i t}+\beta_{10} \text { Earn }_{i t}+\varepsilon_{i t}
\end{gathered}
$$

To be consistent with Zang (2012), the unexpected abnormal level of discretionary expenditures are multiplied by (-1) such that higher values indicate greater amounts of unexpected abnormal level of discretionary expenditures reduced by firms to increase reported earnings.

$\mathrm{rmCASH}_{i t}$ is the abnormal cash flow from operations estimated following Roychowdhury (2006), which is defined as the firm specific residuals from the following equation estimated cross-sectionally for each yearindustry combination.

$$
\frac{C F O_{t}}{A_{t-1}}=\alpha_{0}+\alpha_{1}\left(\frac{1}{A_{t-1}}\right)+\beta_{t}\left(\frac{S_{t}}{A_{t-1}}\right)+\beta_{2}\left(\frac{\Delta S_{t}}{A_{t-1}}\right)+\varepsilon_{t}
$$

where $A_{t}$ is the total assetss at the end of period t, $S_{t}$ the sales during period t and $\Delta S_{t}=S_{t}-S_{t-1}$. 
$A T A_{i t}$ is abnormal total accruals, which is the firm-specific residuals derived from following equation estimated cross-sectionally for each industry-year combination:

$\frac{T A_{i t}}{A T_{i t-1}}=\varphi_{0}+\varphi_{1}\left(\frac{1}{A T_{i t-1}}\right)+\varphi_{2}\left(\frac{\Delta R E V_{i t}}{A T_{i t-1}}-\frac{\Delta R E C_{i t}}{A T_{i t-1}}\right)+\varphi_{3}\left(\frac{P P E_{i t}}{A T_{i t-1}}\right)+R O A_{t-1}+\varepsilon_{i t}$

$\operatorname{UnPer} f_{i \mu(t-1, t-2)}$ is a dummy variable and it equals one if firm $i$ 's average performance $\left(R O A_{\mu(t-1, t-2)}\right)$ of the past two years is below that of its peer group by no more than 0.05 . In other words, $R O A_{\mu(t-1, t-2)}-$ $\operatorname{Peer}\left(R O A_{\mu(t-1, t-2)}\right)$ is within the range of $(-0.05,0) . R O A_{\mu(t-1, t-2)}$ is calculated using $\frac{R O A_{t-2}+R O A_{t-1}}{2}$. Achieve $_{i t}$ is a dummy variable and it equals one if firm $i$ 's current year's performance $\left(R O A_{t}\right)$ is above the peer group by no more than 0.05 . In other words, $R O A_{t}-\operatorname{Peer}\left(R O A_{t}\right)$ is within the range of $(0,0.05)$. Achieve $_{i t} * \operatorname{UnPerf}_{i \mu(t-1, t-2)}$ is the interaction term of Achieve $_{i t}$ and $U n P \operatorname{erf} f_{i \mu(t-1, t-2)}$

$\operatorname{LogAT} \mathrm{T}_{i t}$ is the natural logarithm of total assets of firm $i$ for year $t . \mathrm{BM}_{i t}$ is the book value of equity divided by market value of equity in year $t$ for firm $i$. $\mathrm{ROA}_{i t}$ is return on assets defined as income before extraordinary items in year $t$ divided by the average of total assets. $L E V_{i t}$ is total liability divided by total assets in year $t$.

Threshold $1_{i t}$ is the indicator variable equal to 1 if the firm avoids losses by a small margin, which is defined as income before extraordinary items scaled by the beginning market value within the range of [0.02]. Threshold $2_{i t}$ is the indicator variable equals to 1 if the firm avoids earnings declines by a small margin, which is defined as change in the income before extraordinary items from year $t-1$ to year $\mathrm{t}$, scaled by the beginning market value within the range of [0.01]. Threshold $3_{i t}$ is an indicator variable equal to 1 if the firm avoids negative earnings surprises by a small margin, which is defined as earnings surprises scaled by beginning price per share within the range of [0.0025].

Table 14

\section{Accruals Management of Firms Missing Current Year's Expected Peer Performance Benchmark}




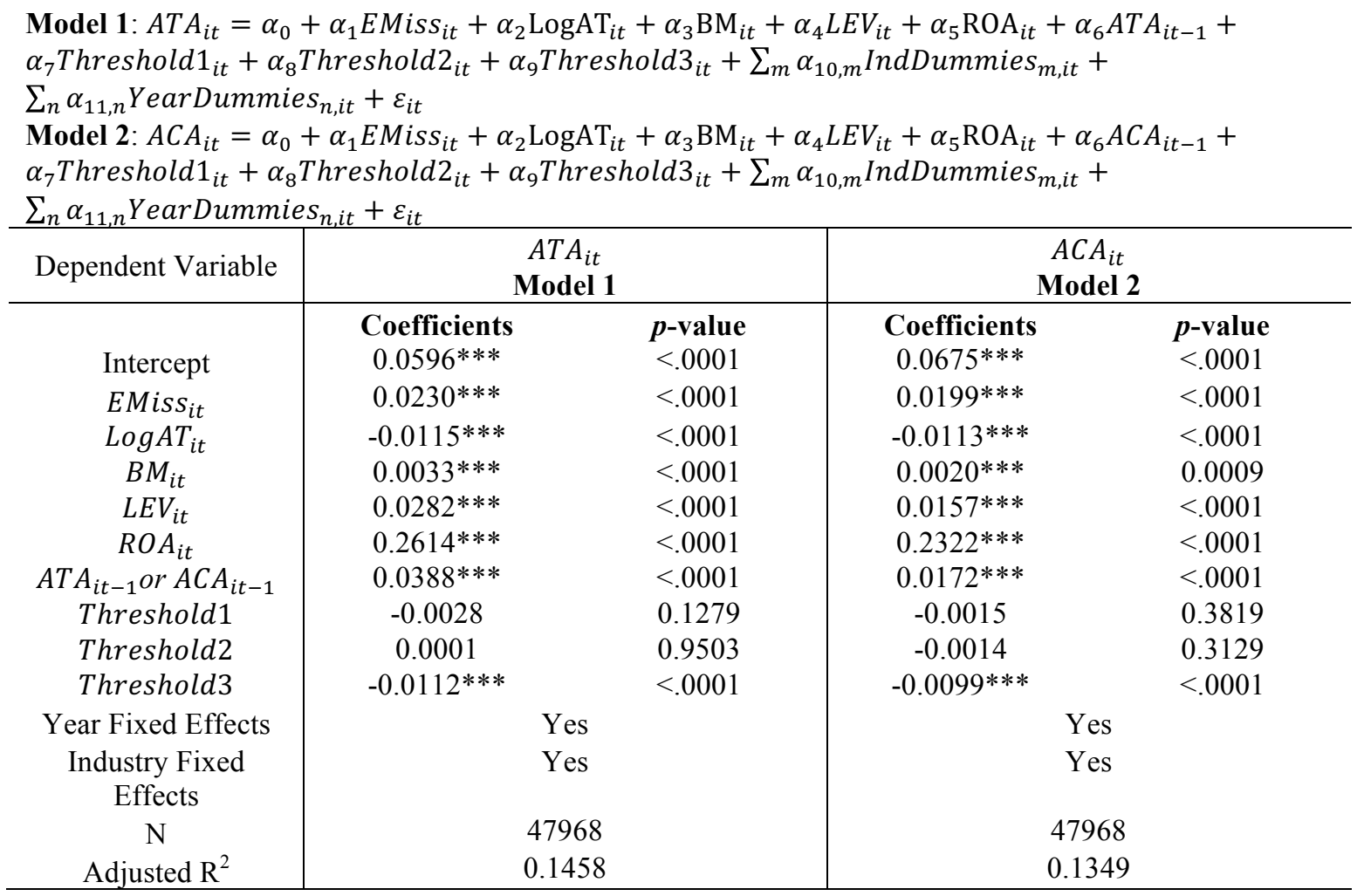

$*, * *, * * *$ denotes significance at $10 \%, 5 \%$ and $1 \%$ level respectively.

$A T A_{i t}$ is abnormal total accruals, which is the firm-specific residuals derived from following equation estimated cross-sectionally for each industry-year combination:

$\frac{T A_{i t}}{A T_{i t-1}}=\varphi_{0}+\varphi_{1}\left(\frac{1}{A T_{i t-1}}\right)+\varphi_{2}\left(\frac{\Delta R E V_{i t}}{A T_{i t-1}}-\frac{\Delta R E C_{i t}}{A T_{i t-1}}\right)+\varphi_{3}\left(\frac{P P E_{i t}}{A T_{i t-1}}\right)+R O A_{t-1}+\varepsilon_{i t}$

$A C A_{i t}$ is abnormal current accruals, which is defined as the firm specific residuals from the following equation estimated cross-sectionally for each year-industry combination.

$\frac{C A_{i t}}{A T_{i t-1}}=\varphi_{0}+\varphi_{1}\left(\frac{1}{A T_{i t-1}}\right)+\varphi_{2}\left(\frac{\Delta R E V_{i t}}{A T_{i t-1}}-\frac{\Delta R E C_{i t}}{A T_{i t-1}}\right)+R O A_{t-1}+\varepsilon_{i t}$

EMiss ${ }_{i t}$ is a dummy variable and it equals one if if firm $i$ 's expected performance Forecasted_EPS $S_{t}$ at year $t$ is below its peer group's expected performance for year $t$. Firm i's expected performance

Forecasted_EPS is calculated using analysts' consensus forecasted EPS scaled by scaled by assets per share at the beginning of the fiscal year. Consensus analyst forecasted EPS are the mean analysts' forecasts for the next period.

$\operatorname{LogAT} i t$ is the natural logarithm of total assets of firm $i$ for year $t . \mathrm{BM}_{i t}$ is the book value of equity divided by market value of equity in year $t$ for firm $i . \mathrm{ROA}_{i t}$ is return on assets defined as income before

extraordinary items in year $t$ divided by the average of total assets. $L E V_{i t}$ is total liability divided by total assets in year $t$.

Threshold $1_{i t}$ is the indicator variable equal to 1 if the firm avoids losses by a small margin, which is defined as income before extraordinary items scaled by the beginning market value within the range of [0.02]. Threshold $2_{i t}$ is the indicator variable equals to 1 if the firm avoids earnings declines by a small margin, which is defined as change in the income before extraordinary items from year $t-1$ to year $\mathrm{t}$, scaled by the beginning market value within the range of [0.01]. Threshold $3_{i t}$ is an indicator variable equal to 1 if the firm avoids negative earnings surprises by a small margin, which is defined as earnings surprises scaled by beginning price per share within the range of [0.0025].

Table 15 


\section{Accruals Management of Firms Missing Current Year's Expected Peer Performance Benchmark and Achieving Current Year's Peer Performance Benchmark}

\begin{tabular}{|c|c|c|c|c|}
\hline Dependent Variable & \multicolumn{2}{|c|}{ Model 1: $A T A_{i t}$} & \multicolumn{2}{|c|}{ Model 1: $A C A_{i t}$} \\
\hline Intercent & $\begin{array}{c}\text { Coefficients } \\
0.0576^{* * *}\end{array}$ & $\begin{array}{c}\boldsymbol{p} \text {-value } \\
<.0001\end{array}$ & $\begin{array}{c}\text { Coefficients } \\
0.0656^{* * *}\end{array}$ & $\begin{array}{c}\boldsymbol{p} \text {-value } \\
<.0001\end{array}$ \\
\hline Achieve $_{i t}$ & $0.0027 *$ & 0.0535 & 0.0006 & 0.6234 \\
\hline EUnPerf $_{i t}$ & -0.0014 & 0.2568 & $-0.0029 * *$ & 0.0139 \\
\hline $\begin{array}{l}\text { Achieve }_{i t} \\
* \text { EUnPerf }_{i t}\end{array}$ & $0.0094 * * *$ & 0.0001 & $0.0080 * * *$ & 0.0006 \\
\hline $\log _{A} T_{i t}$ & $-0.0103 * * *$ & $<.0001$ & $-0.0101 * * *$ & $<.0001$ \\
\hline$B M_{i t}$ & $0.0048 * * *$ & $<.0001$ & $0.0034 * * *$ & $<.0001$ \\
\hline$L E V_{i t}$ & $0.0324 * * *$ & $<.0001$ & $0.0195 * * *$ & $<.0001$ \\
\hline$R O A_{i t}$ & $0.2336 * * *$ & $<.0001$ & $0.2086^{* * *}$ & $<.0001$ \\
\hline$A T A_{i t-1}$ or $A C A_{i t-1}$ & $0.0382 * * *$ & $<.0001$ & $0.0164 * * *$ & $<.0001$ \\
\hline Threshold 1 & 0.0000 & 0.9980 & 0.0011 & 0.5354 \\
\hline Threshold2 & -0.0019 & 0.2112 & $-0.0031 * *$ & 0.0292 \\
\hline Threshold3 & $-0.0115 * * *$ & $<.0001$ & $-0.0100 * * *$ & $<.0001$ \\
\hline Year Fixed Effects & \multicolumn{2}{|c|}{ Yes } & \multicolumn{2}{|c|}{ Yes } \\
\hline $\begin{array}{c}\text { Industry Fixed } \\
\text { Effects }\end{array}$ & \multicolumn{2}{|c|}{ Yes } & \multicolumn{2}{|c|}{ Yes } \\
\hline $\mathrm{N}$ & \multicolumn{2}{|c|}{47968} & \multicolumn{2}{|c|}{47968} \\
\hline Adjusted $\mathrm{R}^{2}$ & \multicolumn{2}{|c|}{0.1384} & \multicolumn{2}{|c|}{0.1284} \\
\hline
\end{tabular}

$*, * *, * * *$ denotes significance at $10 \%, 5 \%$ and $1 \%$ level respectively.

$A T A_{i t}$ is abnormal total accruals, which is the firm-specific residuals derived from following equation estimated cross-sectionally for each industry-year combination:

$\frac{T A_{i t}}{A T_{i t-1}}=\varphi_{0}+\varphi_{1}\left(\frac{1}{A T_{i t-1}}\right)+\varphi_{2}\left(\frac{\Delta R E V_{i t}}{A T_{i t-1}}-\frac{\Delta R E C_{i t}}{A T_{i t-1}}\right)+\varphi_{3}\left(\frac{P P E_{i t}}{A T_{i t-1}}\right)+R O A_{t-1}+\varepsilon_{i t}$

$A C A_{i t}$ is abnormal current accruals, which is defined as the firm specific residuals from the following equation estimated cross-sectionally for each year-industry combination.

$\frac{C A_{i t}}{A T_{i t-1}}=\varphi_{0}+\varphi_{1}\left(\frac{1}{A T_{i t-1}}\right)+\varphi_{2}\left(\frac{\Delta R E V_{i t}}{A T_{i t-1}}-\frac{\Delta R E C_{i t}}{A T_{i t-1}}\right)+R O A_{t-1}+\varepsilon_{i t}$

EUnPerf $f_{i t}$ is a dummy variable and it equals one if if firm $i$ 's expected performance Forecasted_EPS $S_{t}$ at year $t$ is below its peer group's expected performance by no more than 0.05 for year $t$. In other words, Forecasted_EPS - Peer $\left(\right.$ Forecasted $\left._{E P S_{t}}\right)$ is within $(-0.05,0)$. Firm i's expected performance

Forecasted_EPS $S_{t}$ is calculated using analysts' consensus forecasted EPS scaled by scaled by assets per share at the beginning of the fiscal year. Consensus analyst forecasted EPS are the mean analysts' forecasts for the next period.

Achieve $_{i t}$ is a dummy variable and it equals one if firm $i$ 's current year's performance $\left(R O A_{t}\right)$ is above the peer group by no more than 0.05 . In other words, $R O A_{t}-\operatorname{Peer}\left(R O A_{t}\right)$ is within the range of $(0,0.05)$. Achieve $_{i t} *$ EUnPerf $_{i t}$ is the interaction term of Achieve $_{i t}$ and EUnPerf $_{i t}$.

$\operatorname{LogAT} T_{i t}$ is the natural logarithm of total assets of firm $i$ for year $t . \mathrm{BM}_{i t}$ is the book value of equity divided by market value of equity in year $t$ for firm $i$. $\mathrm{ROA}_{i t}$ is return on assets defined as income before extraordinary items in year $t$ divided by the average of total assets. $L E V_{i t}$ is total liability divided by total assets in year $t$. 
Threshold $1_{i t}$ is the indicator variable equal to 1 if the firm avoids losses by a small margin, which is defined as income before extraordinary items scaled by the beginning market value within the range of [0.02]. Threshold $2_{i t}$ is the indicator variable equals to 1 if the firm avoids earnings declines by a small margin, which is defined as change in the income before extraordinary items from year $t-1$ to year $\mathrm{t}$, scaled by the beginning market value within the range of [0.01]. Threshold $3_{i t}$ is an indicator variable equal to 1 if the firm avoids negative earnings surprises by a small margin, which is defined as earnings surprises scaled by beginning price per share within the range of [0.0025].

Table 16 


\section{Real Earnings Management of Firms Missing Current Year's Expected Peer Performance Benchmark}

\begin{tabular}{|c|c|c|c|c|}
\hline \multirow[t]{2}{*}{ Dependent Variable } & \multicolumn{2}{|c|}{$\begin{array}{c}\text { rmUDISX }_{i t} \\
\text { Model } 1\end{array}$} & \multicolumn{2}{|c|}{$\begin{array}{c}\operatorname{rmCASH}_{i t} \\
\text { Model } 2\end{array}$} \\
\hline & Coefficients & $p$-value & Coefficients & $p$-value \\
\hline Intercept & $0.0358 * * *$ & $<.0001$ & $0.0676 * * *$ & $<.0001$ \\
\hline EMiss $_{i t}$ & 0.0010 & 0.221 & -0.0015 & 0.1282 \\
\hline $\log A T_{i t}$ & $-0.0068 * * *$ & $<.0001$ & $0.0025 * * *$ & $<.0001$ \\
\hline$B M_{i t}$ & $0.0044 * * *$ & $<.0001$ & $-0.0060 * * *$ & $<.0001$ \\
\hline$L E V_{i t}$ & $0.0414 * * *$ & $<.0001$ & $-0.0498 * * *$ & $<.0001$ \\
\hline$R O A_{i t}$ & $0.1496 * * *$ & $<.0001$ & $0.58888 * *$ & $<.0001$ \\
\hline Threshold $1_{i t}$ & $-0.0089 * * *$ & $<.0001$ & $0.0041 * *$ & 0.0125 \\
\hline Threshold2 & $-0.0054 * * *$ & $<.0001$ & -0.0011 & 0.4169 \\
\hline Threshold $3_{i t}$ & -0.0008 & 0.3374 & $0.0046 * * *$ & $<.0001$ \\
\hline$A T A_{i t}$ & $-0.5909 * * *$ & $<.0001$ & $-0.6898 * * *$ & $<.0001$ \\
\hline Year Fixed Effects & \multicolumn{2}{|c|}{ Yes } & \multicolumn{2}{|c|}{ Yes } \\
\hline $\begin{array}{l}\text { Industry Fixed } \\
\text { Effects }\end{array}$ & \multicolumn{2}{|c|}{ Yes } & \multicolumn{2}{|c|}{ Yes } \\
\hline $\mathrm{N}$ & \multicolumn{2}{|c|}{46930} & \multicolumn{2}{|c|}{46930} \\
\hline Adjusted $\mathrm{R}^{2}$ & \multicolumn{2}{|c|}{0.3859} & \multicolumn{2}{|c|}{0.5998} \\
\hline
\end{tabular}

$*, * *, * * *$ denotes significance at $10 \%, 5 \%$ and $1 \%$ level respectively.

rmUDISX $_{i t}$ is the unexpected abnormal level of discretionary expenditures estimated following Zang (2012). First, estimate the abnormal level of discretionary expenditures $\left(\mathrm{rmDISX}_{i t}\right)$ as the residuals from the regression below. The regression is estimated cross-sectionally for each year and each two-digit SIC code with at least ten observations.

$\frac{\operatorname{DISX}_{i t}}{A_{i t-1}}=\alpha_{0}+\alpha_{1}\left(\frac{1}{A_{i t-1}}\right)+\alpha_{2}\left(\frac{S_{i t-1}}{A_{i t-1}}\right)+\varepsilon_{i t}$

Second, estimate the unexpected abnormal level of discretionary expenditures ( rmUDISX $_{i t}$ ) as the residuals from the regression below. The regression is estimated cross-sectionally for each industry-year combination.

$$
\begin{gathered}
\operatorname{rmDISX}_{i t}=\beta_{0}+\beta_{1} \text { Market }_{\text {Share }_{i t-1}}+\beta_{2} \text { ZSCORE }_{i t-1}+\beta_{3} \text { TAX }_{\text {Rate }_{i t}}+\beta_{4} \text { BIG }_{i t}+\beta_{5} \text { NOA A }_{i t-1} \\
+\beta_{6} \text { CYCLE }_{i t-1} \\
+\beta_{7} \text { ROA }_{i t}+\beta_{8} \log _{\text {o }} T_{i t}+\beta_{9} \text { Mto }_{i t}+\beta_{10} \text { Earn }_{i t}+\varepsilon_{i t}
\end{gathered}
$$

To be consistent with Zang (2012), the unexpected abnormal level of discretionary expenditures are multiplied by (-1) such that higher values indicate greater amounts of unexpected abnormal level of discretionary expenditures reduced by firms to increase reported earnings.

$\mathrm{rmCASH}_{i t}$ is the abnormal cash flow from operations estimated following Roychowdhury (2006), which is defined as the firm specific residuals from the following equation estimated cross-sectionally for each yearindustry combination.

$$
\frac{C F O_{t}}{A_{t-1}}=\alpha_{0}+\alpha_{1}\left(\frac{1}{A_{t-1}}\right)+\beta_{t}\left(\frac{S_{t}}{A_{t-1}}\right)+\beta_{2}\left(\frac{\Delta S_{t}}{A_{t-1}}\right)+\varepsilon_{t}
$$

where $A_{t}$ is the total assetss at the end of period $\mathrm{t}, S_{t}$ the sales during period t and $\Delta S_{t}=S_{t}-S_{t-1}$. $A T A_{i t}$ is abnormal total accruals, which is the firm-specific residuals derived from following equation estimated cross-sectionally for each industry-year combination: 
$\frac{T A_{i t}}{A T_{i t-1}}=\varphi_{0}+\varphi_{1}\left(\frac{1}{A T_{i t-1}}\right)+\varphi_{2}\left(\frac{\Delta R E V_{i t}}{A T_{i t-1}}-\frac{\Delta R E C_{i t}}{A T_{i t-1}}\right)+\varphi_{3}\left(\frac{P P E_{i t}}{A T_{i t-1}}\right)+R O A_{t-1}+\varepsilon_{i t}$

$E_{\text {Miss }}$ it is a dummy variable and it equals one if if firm $i$ 's expected performance Forecasted_EPS Fat $_{t}$ year $t$ is below its peer group's expected performance for year $t$. Firm i's expected performance

Forecasted_EPS $S_{t}$ is calculated using analysts' consensus forecasted EPS scaled by scaled by assets per share at the beginning of the fiscal year. Consensus analyst forecasted EPS are the mean analysts' forecasts for the next period.

$\operatorname{LogAT} \mathrm{T}_{i t}$ is the natural logarithm of total assets of firm $i$ for year $t . \mathrm{BM}_{i t}$ is the book value of equity divided by market value of equity in year $t$ for firm $i$. $\mathrm{ROA}_{i t}$ is return on assets defined as income before

extraordinary items in year $t$ divided by the average of total assets. $L E V_{i t}$ is total liability divided by total assets in year $t$.

Threshold $1_{i t}$ is the indicator variable equal to 1 if the firm avoids losses by a small margin, which is defined as income before extraordinary items scaled by the beginning market value within the range of [0.02]. Threshold $2_{i t}$ is the indicator variable equals to 1 if the firm avoids earnings declines by a small margin, which is defined as change in the income before extraordinary items from year $t-1$ to year $\mathrm{t}$, scaled by the beginning market value within the range of [0.01]. Threshold $3_{i t}$ is an indicator variable equal to 1 if the firm avoids negative earnings surprises by a small margin, which is defined as earnings surprises scaled by beginning price per share within the range of [0.0025].

The sample period spans the years 1990 to 2012.

Table 17 


\section{Real Earnings Management of Firms Missing Current Year's Expected Peer Performance Benchmark and Achieving Current Year' Peer Performance Benchmark}

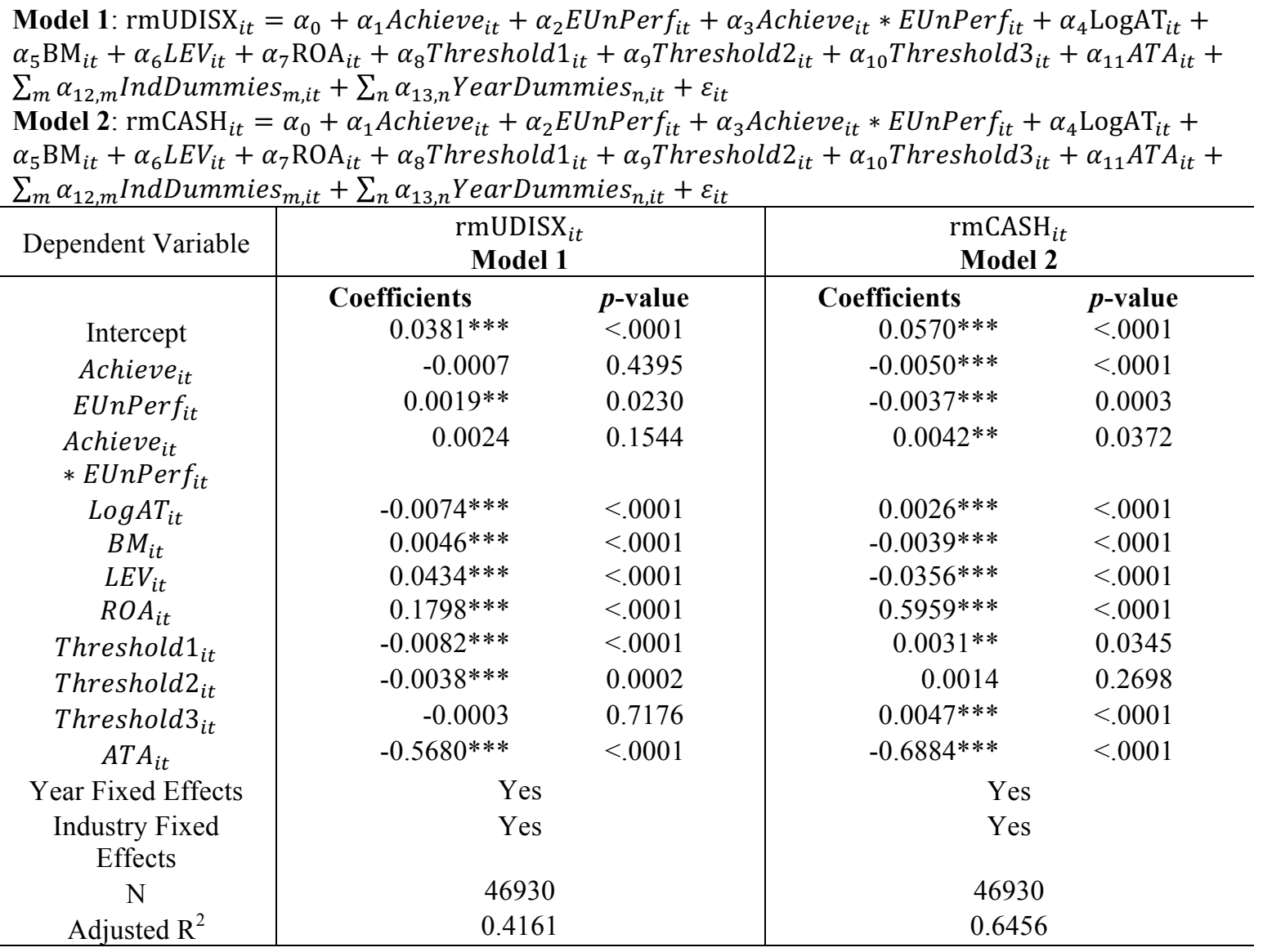

$*, * *, * * *$ denotes significance at $10 \%, 5 \%$ and $1 \%$ level respectively.

rmUDISX $_{i t}$ is the unexpected abnormal level of discretionary expenditures estimated following Zang (2012). First, estimate the abnormal level of discretionary expenditures $\left(\operatorname{rmDISX}_{i t}\right)$ as the residuals from the regression below. The regression is estimated cross-sectionally for each year and each two-digit SIC code with at least ten observations.

$\frac{\text { DISX }_{i t}}{A_{i t-1}}=\alpha_{0}+\alpha_{1}\left(\frac{1}{A_{i t-1}}\right)+\alpha_{2}\left(\frac{S_{i t-1}}{A_{i t-1}}\right)+\varepsilon_{i t}$

Second, estimate the unexpected abnormal level of discretionary expenditures $\left(\operatorname{rmUDISX}_{i t}\right)$ as the residuals from the regression below. The regression is estimated cross-sectionally for each industry-year combination.

$$
\begin{gathered}
\operatorname{rmDISX}_{i t}=\beta_{0}+\beta_{1} \text { Market }_{\text {Share }_{i t-1}}+\beta_{2} \text { ZSCORE }_{i t-1}+\beta_{3} \text { TAX }_{\text {Rate }}+\beta_{4} \text { BIG8 }_{i t}+\beta_{5} \text { NOA A }_{i t-1} \\
+\beta_{6} \text { CYCLE } \\
+\beta_{7 t-1} \text { ROA }_{i t}+\beta_{8} \operatorname{LogAT}_{i t}+\beta_{9} \text { MtoB }_{i t}+\beta_{10} \text { Earn }_{i t}+\varepsilon_{i t}
\end{gathered}
$$

To be consistent with Zang (2012), the unexpected abnormal level of discretionary expenditures are multiplied by (-1) such that higher values indicate greater amounts of unexpected abnormal level of discretionary expenditures reduced by firms to increase reported earnings.

$\mathrm{rmCASH}_{i t}$ is the abnormal cash flow from operations estimated following Roychowdhury (2006), which is defined as the firm specific residuals from the following equation estimated cross-sectionally for each yearindustry combination.

$$
\frac{C F O_{t}}{A_{t-1}}=\alpha_{0}+\alpha_{1}\left(\frac{1}{A_{t-1}}\right)+\beta_{t}\left(\frac{S_{t}}{A_{t-1}}\right)+\beta_{2}\left(\frac{\Delta S_{t}}{A_{t-1}}\right)+\varepsilon_{t}
$$


where $A_{t}$ is the total assetss at the end of period t, $S_{t}$ the sales during period t and $\Delta S_{t}=S_{t}-S_{t-1}$. $A T A_{i t}$ is abnormal total accruals, which is the firm-specific residuals derived from following equation estimated cross-sectionally for each industry-year combination:

$\frac{T A_{i t}}{A T_{i t-1}}=\varphi_{0}+\varphi_{1}\left(\frac{1}{A T_{i t-1}}\right)+\varphi_{2}\left(\frac{\Delta R E V_{i t}}{A T_{i t-1}}-\frac{\Delta R E C_{i t}}{A T_{i t-1}}\right)+\varphi_{3}\left(\frac{P P E_{i t}}{A T_{i t-1}}\right)+R O A_{t-1}+\varepsilon_{i t}$

EUnPerf $f_{i t}$ is a dummy variable and it equals one if if firm $i$ 's expected performance Forecasted_EPS $S_{t}$ at year $t$ is below its peer group's expected performance by no more than 0.05 for year $t$. In other words, Forecasted_EPS $-\operatorname{Peer}\left(\right.$ Forecasted $\left._{E P S_{t}}\right)$ is within $(-0.05,0)$. Firm i's expected performance

Forecasted_EPS $S_{t}$ is calculated using analysts' consensus forecasted EPS scaled by scaled by assets per share at the beginning of the fiscal year. Consensus analyst forecasted EPS are the mean analysts' forecasts for the next period.

Achieve $_{i t}$ is a dummy variable and it equals one if firm $i$ 's current year's performance $\left(R O A_{t}\right)$ is above the peer group by no more than 0.05 . In other words, $R O A_{t}-\operatorname{Peer}\left(R O A_{t}\right)$ is within the range of $(0,0.05)$. Achieve $_{i t} * E_{\text {EnPerf }}$ it is the interaction term of Achieve $_{i t}$ and $E U n P e r f_{i t}$.

$\operatorname{LogAT}_{i t}$ is the natural logarithm of total assets of firm $i$ for year $t . \mathrm{BM}_{i t}$ is the book value of equity divided by market value of equity in year $t$ for firm $i$. ROA $i t$ is return on assets defined as income before extraordinary items in year $t$ divided by the average of total assets. $L E V_{i t}$ is total liability divided by total assets in year $t$.

Threshold $1_{i t}$ is the indicator variable equal to 1 if the firm avoids losses by a small margin, which is defined as income before extraordinary items scaled by the beginning market value within the range of [0.02]. Threshold $2_{i t}$ is the indicator variable equals to 1 if the firm avoids earnings declines by a small margin, which is defined as change in the income before extraordinary items from year $t-1$ to year $\mathrm{t}$, scaled by the beginning market value within the range of [0.01]. Threshold $3_{i t}$ is an indicator variable equal to 1 if the firm avoids negative earnings surprises by a small margin, which is defined as earnings surprises scaled by beginning price per share within the range of [0.0025].

The sample period spans the years 1990 to 2012.

Table 18 


\section{Accruals Management of Firms Missing First Three Quarters' Cumulative Peer Performance Benchmark}

\begin{tabular}{|c|c|c|c|c|}
\hline Dependent Variable & \multicolumn{2}{|c|}{$\begin{array}{l}A T A_{i t(q 4)} \\
\text { Model } 1 \\
\end{array}$} & \multicolumn{2}{|c|}{$\begin{array}{c}A C A_{i t}(q 4) \\
\text { Model } 2\end{array}$} \\
\hline & Coefficients & $p$-value & Coefficients & $p$-value \\
\hline Intercept & $0.0193 * * *$ & $<.0001$ & $0.0259 * * *$ & $<.0001$ \\
\hline $\operatorname{Miss}_{i \sum(q 1, q 2, q 3)}$ & $0.0098 * * *$ & $<.0001$ & $0.0111 * * *$ & $<.0001$ \\
\hline $\log A T_{i q 4}$ & $-0.0049 * * *$ & $<.0001$ & $-0.0055^{* * *}$ & $<.0001$ \\
\hline$B M_{i q 4}$ & 0.0004 & 0.3678 & $-0.0011 * * *$ & 0.0085 \\
\hline$L E V_{i q 4}$ & $0.0056 * * *$ & $<.0001$ & -0.0019 & 0.1728 \\
\hline$R O A_{i q 4}$ & $0.5941 * * *$ & $<.0001$ & $0.5686^{* * *}$ & $<.0001$ \\
\hline$A T A_{i \sum(q 1, q 2, q 3)}$ & $-0.0351 * * *$ & $<.0001$ & $-0.0471 * * *$ & $<.0001$ \\
\hline Threshold 1 & 0.0000 & 0.9557 & -0.0002 & 0.7112 \\
\hline Threshold2 & -0.0006 & 0.3607 & -0.0010 & 0.1599 \\
\hline Threshold3 & $-0.0019 * * *$ & 0.0051 & $-0.0013 * *$ & 0.0405 \\
\hline Year Fixed Effects & & \multicolumn{2}{|c|}{ Yes } \\
\hline Industry Fixed & \multirow{2}{*}{\multicolumn{2}{|c|}{ Yes }} & \multicolumn{2}{|c|}{ Yes } \\
\hline $\begin{array}{c}\text { Effects } \\
\mathrm{N}\end{array}$ & & & & \\
\hline $\begin{array}{c}\mathrm{N} \\
\text { Adjusted } \mathrm{R}^{2}\end{array}$ & \multicolumn{2}{|c|}{29589} & \multicolumn{2}{|c|}{29589} \\
\hline Adjusted $\mathrm{R}^{2}$ & \multicolumn{2}{|c|}{0.3732} & \multicolumn{2}{|c|}{0.3637} \\
\hline
\end{tabular}

$*, * *, * * *$ denotes significance at $10 \%, 5 \%$ and $1 \%$ level respectively.

$\operatorname{Miss}_{i t} \sum(q 1, q 2, q 3)$ is a dummy variable which equals one if firm i's cumulative performance $\left(\operatorname{ROA}_{\Sigma(q 1, q 2, q 3)}\right)$ of the first three quarters in year $\mathrm{t}$ is below that of its peer group. $R O A_{\sum(q 1, q 2, q 3)}$ is calculated using income before extraordinary items in quarter 1 , add that in quarter 2 , quarter 3 , then use the cumulative number divided by average of assets at the beginning of quarter 1 and the end of quarter 3;

$A T A_{i t(q 4)}$ is the abnormal total accrual at the fourth quarter in year $\mathrm{t}$, and $A C A_{i t(q 4)}$ is the abnormal working capital accrual at the fourth quarter in year $t$. The definitions of abnormal total accrual and abnormal working capital accrual are explained in the previous tables.

$\operatorname{LogAT}_{i t(q)}$ is natural logarithm of asset at fourth quarter of firm $i$ for year $t ; \mathrm{BM}_{i t(q 4)}$ is book value of equity divided by market value of equity at fourth quarter of year $t$ for firm $i ; L E V_{i t(q)}$ is total liability divided by total assets at fourth quarter of year $t ; \mathrm{ROA}_{i t(q 4)}$ is income before extraordinary items at fourth quarter of year $t$ in year $t$ divided by the average of total assets of the fourth quarter and beginning of fourth quarter in year $t ; A T A_{i t \sum(q 1, q 2, q 3)}$ is the abnormal total accrual of the first three quarters at year $\mathrm{t}$, and $A C A_{i t} \sum(q 1, q 2, q 3)$ is abnormal working capital accrual of the first three quarters at year $t$. The definitions of abnormal total accrual and abnormal working capital accrual are explained in the previous tables.

Threshold $1_{i t(q 4)}$, Threshold $2_{i t(q 4)}$ or Threshold $3_{i t(q 4)}$ equal one if firm i just meet and beat threshold 1 , threshold 2 or threshold 3 in the fourth quarter of year $t$. respectively. The definition of just meet and beat each threshold is explained in the previous section.

Table 19 


\section{Accruals Management of Firms Missing First Three Quarters' Cumulative Peer Performance Benchmark and Achieving Current Year's Peer Performance Benchmark}

\begin{tabular}{|c|c|c|c|c|}
\hline \multicolumn{5}{|c|}{ 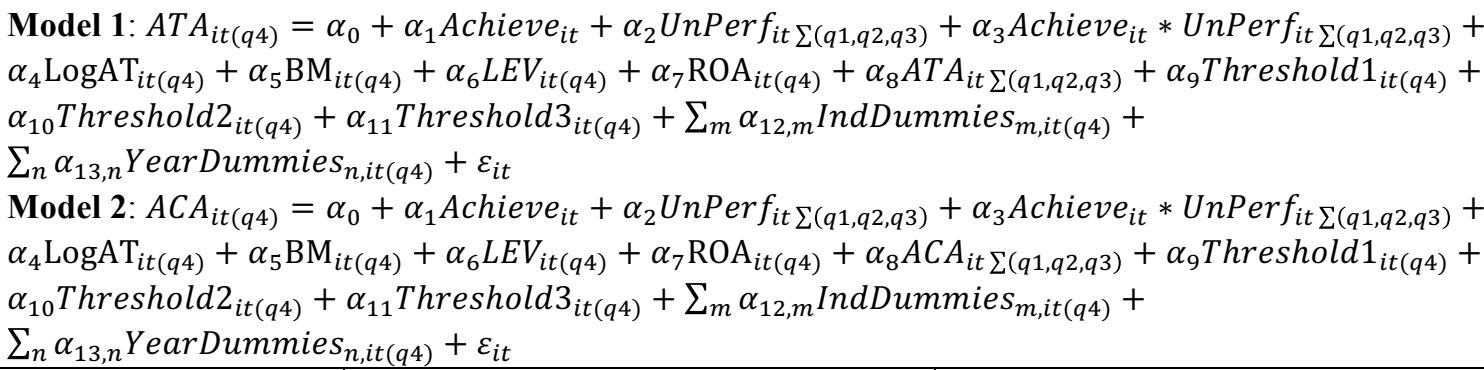 } \\
\hline Dependent Variable & \multicolumn{2}{|c|}{$\begin{array}{l}A T A_{i t(q 4)} \\
\text { Model } 1 \\
\end{array}$} & \multicolumn{2}{|c|}{$\begin{array}{l}A C A_{i t(q 4)} \\
\text { Model } 2 \\
\end{array}$} \\
\hline Intercept & $\begin{array}{c}\text { Coefficients } \\
0.0314^{* * *}\end{array}$ & $\begin{array}{l}p \text {-value } \\
<.0001\end{array}$ & $\begin{array}{c}\text { Coefficients } \\
0.0394^{* * *}\end{array}$ & $\begin{array}{c}p \text {-value } \\
<.0001\end{array}$ \\
\hline Achieve $_{i t}$ & $-0.0137 * * *$ & $<.0001$ & $-0.0154 * * *$ & $<.0001$ \\
\hline $\operatorname{UnPerf}_{i \Sigma(q 1, q 2, q 3)}$ & $-0.0082 * * *$ & $<.0001$ & $-0.0091 * * *$ & $<.0001$ \\
\hline $\begin{array}{l}\text { Achieve }_{i t} \\
* \text { UnPerf }_{i t} \sum(q 1, q 2, q 3)\end{array}$ & $0.0113 * * *$ & $<.0001$ & $0.0124 * * *$ & $<.0001$ \\
\hline $\log A T_{i q 4}$ & $-0.0047 * * *$ & $<.0001$ & $-0.0053 * * *$ & $<.0001$ \\
\hline$B M_{i q 4}$ & $0.0007 *$ & 0.0837 & $-0.0007^{*}$ & 0.0932 \\
\hline$L E V_{i q 4}$ & $0.0067 * * *$ & $<.0001$ & -0.0008 & 0.5936 \\
\hline$R O A_{i q 4}$ & $0.6059 * * *$ & $<.0001$ & $0.5821 * * *$ & $<.0001$ \\
\hline$A T A_{i \sum(q 1, q 2, q 3)}$ & $-0.0335 * * *$ & $<.0001$ & $-0.0457 * * *$ & $<.0001$ \\
\hline Threshold 1 & 0.0005 & 0.4322 & 0.0003 & 0.6486 \\
\hline Threshold2 & -0.0005 & 0.4927 & -0.0008 & 0.2548 \\
\hline Threshold3 & $-0.0018 * * *$ & 0.0057 & $-0.0013 * *$ & 0.0447 \\
\hline Year Fixed Effects & \multicolumn{2}{|c|}{ Yes } & \multicolumn{2}{|c|}{ Yes } \\
\hline Industry Fixed Effects & & & \multicolumn{2}{|c|}{ Yes } \\
\hline $\mathrm{N}$ & \multicolumn{2}{|c|}{29589} & \multirow{2}{*}{\multicolumn{2}{|c|}{$\begin{array}{l}29589 \\
0.3637\end{array}$}} \\
\hline Adjusted $\mathrm{R}^{2}$ & \multicolumn{2}{|c|}{0.3732} & & \\
\hline
\end{tabular}

$*, * *, * *$ denotes significance at $10 \%, 5 \%$ and $1 \%$ level respectively.

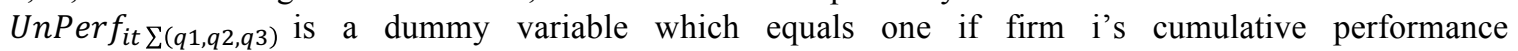
$\left(R O A_{\Sigma(q 1, q 2, q 3)}\right)$ of the first three quarters in year $\mathrm{t}$ is below that of its peer group by no more than 0.05 . In other words, $R O A_{\Sigma(q 1, q 2, q 3)}-\operatorname{Peer}\left(R O A_{\Sigma(q 1, q 2, q 3)}\right)$ is within the range of $(-0.05,0) . R O A_{\Sigma(q 1, q 2, q 3)}$ is calculated using income before extraordinary items in quarter 1 , add that in quarter 2 , quarter 3 , then use the cumulative number divided by average of assets at the beginning of quarter 1 and the end of quarter 3 ; Achieve $_{i t}$ is a dummy variable and it equals one if firm $i$ 's current year's performance $\left(R O A_{t}\right)$ is above the peer group by no more than 0.05 . In other words, $R O A_{t}-\operatorname{Peer}\left(R O A_{t}\right)$ is within the range of $(0,0.05)$. Achieve $_{i t} * \operatorname{UnPerf}_{i t \Sigma(q 1, q 2, q 3)}$ is the interaction term of $\operatorname{Achieve}_{i t}$ and $\operatorname{UnPerf}_{i t \Sigma(q 1, q 2, q 3)}$. $A T A_{i t(q))}$ is the abnormal total accrual at the fourth quarter in year $\mathrm{t}$, and $A C A_{i t(q 4)}$ is the abnormal working capital accrual at the fourth quarter in year $t$. The definitions of abnormal total accrual and abnormal working capital accrual are explained in the previous tables.

$\operatorname{LogAT}_{i t(q))}$ is natural logarithm of asset at fourth quarter of firm $i$ for year $t ; \mathrm{BM}_{i t(q 4)}$ is book value of equity divided by market value of equity at fourth quarter of year $t$ for firm $i$; $L E V_{i t(q))}$ is total liability divided by total assets at fourth quarter of year $t ; \mathrm{ROA}_{i t(q 4)}$ is income before extraordinary items at fourth quarter of year $t$ in year $t$ divided by the average of total assets of the fourth quarter and beginning of fourth quarter in year $t ; A T A_{i t \sum(q 1, q 2, q 3)}$ is the abnormal total accrual of the first three quarters at year $\mathrm{t}$, and $A C A_{i t} \sum(q 1, q 2, q 3)$ 
is abnormal working capital accrual of the first three quarters at year $t$. The definitions of abnormal total accrual and abnormal working capital accrual are explained in the previous tables.

Threshold $1_{i t(q 4)}$, Threshold $2_{i t(q 4)}$ or Threshold $3_{i t(q 4)}$ equal one if firm i just meet and beat threshold 1 , threshold 2 or threshold 3 in the fourth quarter of year $t$. respectively. The definition of just meet and beat each threshold is explained in the previous section.

Table 20 


\section{Real Earnings Management of Firms Missing First Three Quarters' Cumulative Peer Performance}

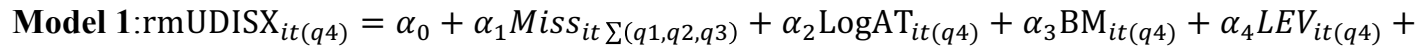

$$
\begin{aligned}
& \alpha_{5} \mathrm{ROA}_{i t(q 4)}+\alpha_{6} \text { Threshold } 1_{i t(q 4)}+\alpha_{7} \text { Threshold } 2_{i t(q 4)}+\alpha_{8} \text { Threshold } 3_{i t(q 4)}+\alpha_{9} \text { AT } A_{i t(q 4)}+ \\
& \sum_{m} \alpha_{10, m} \text { IndDummies }_{m, i t(q 4)}+\sum_{n} \alpha_{11, n} \text { YearDummies }_{n, i t(q 4)}+\varepsilon_{i t}
\end{aligned}
$$

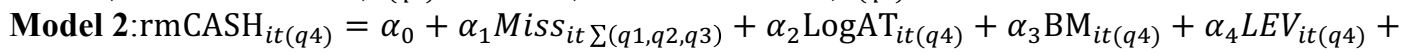

\begin{tabular}{|c|c|c|c|c|}
\hline \multirow[t]{2}{*}{ Dependent Variable } & \multicolumn{2}{|c|}{$\begin{array}{c}\text { rmUDISX }_{i t}(q 4) \\
\text { Model } 1\end{array}$} & \multicolumn{2}{|c|}{$\begin{array}{c}\text { rmCASH }_{i t(q 4)} \\
\text { Model } 2 \\
\end{array}$} \\
\hline & $\begin{array}{c}\text { Coefficients } \\
-0.0020^{*}\end{array}$ & $\begin{array}{c}p \text {-value } \\
0.0719\end{array}$ & $\begin{array}{r}\text { Coefficients } \\
-0.0026^{*}\end{array}$ & $\begin{array}{c}p \text {-value } \\
0.0943\end{array}$ \\
\hline $\operatorname{Miss}_{i \sum(q 1, q 2, q 3)}$ & $-0.0039 * * *$ & $<.0001$ & -0.0007 & 0.1011 \\
\hline $\log A T_{i(q 4)}$ & $-0.0013 * * *$ & $<.0001$ & $0.0005 * * *$ & $<.0001$ \\
\hline$B M_{i(q 4)}$ & $0.0029 * * *$ & $<.0001$ & $-0.0007 * * *$ & 0.0060 \\
\hline$L E V_{i(q 4)}$ & $0.0087 * * *$ & $<.0001$ & $-0.0096 * * *$ & $<.0001$ \\
\hline$R O A_{i(q 4)}$ & $0.2303 * * *$ & $<.0001$ & $0.5964 * * *$ & $<.0001$ \\
\hline Threshold $1_{i t(q 4)}$ & $0.0012 * * *$ & 0.0012 & 0.0004 & 0.3736 \\
\hline Threshold $1_{i t(q 4)}$ & 0.0001 & 0.8265 & -0.0004 & 0.3963 \\
\hline Threshold $1_{i t(q 4)}$ & $-0.0010 * * *$ & 0.0044 & 0.0005 & 0.2486 \\
\hline$A T A_{i t(q 4)}$ & $-0.4084 * * *$ & $<.0001$ & $-0.6737 * * *$ & $<.0001$ \\
\hline Year Fixed Effects & \multicolumn{2}{|c|}{ Yes } & \multicolumn{2}{|c|}{ Yes } \\
\hline Industry Fixed Effects & \multicolumn{2}{|c|}{ Yes } & \multicolumn{2}{|c|}{ Yes } \\
\hline $\mathrm{N}$ & \multicolumn{2}{|c|}{25779} & \multicolumn{2}{|c|}{25779} \\
\hline Adjusted $\mathrm{R}^{2}$ & \multicolumn{2}{|c|}{0.3748} & \multicolumn{2}{|c|}{0.6002} \\
\hline
\end{tabular}

$$
\begin{aligned}
& \alpha_{5} \mathrm{ROA}_{i t(q 4)}+\alpha_{6} \text { Threshold } 1_{i t(q 4)}+\alpha_{7} \text { Threshold } 2_{i t(q 4)}+\alpha_{8} \text { Threshold } 3_{i t(q 4)}+\alpha_{9} \text { AT } A_{i t(q 4)}+ \\
& \sum_{m} \alpha_{10, m} \text { IndDummies }_{m, i t(q 4)}+\sum_{n} \alpha_{11, n} \text { YearDummies }_{n, i t(q 4)}+\varepsilon_{i t}
\end{aligned}
$$

$*, * * * * *$ denotes significance at $10 \%, 5 \%$ and $1 \%$ level respectively.

rmUDISX $_{i t(q 4)}$ is the unexpected abnormal level of discretionary expenditures at the fourth quarter in year $\mathrm{t}$. The definition of unexpected abnormal level of discretionary expenditures is explained in the previous tables.

$\mathrm{rmCASH}_{i t}$ is the abnormal cash flow from operations at the fourth quarter in year $\mathrm{t}$. The definition of abnormal cash flow from operations is explained in the pervious tables.

$\operatorname{Miss}_{\text {it } \sum(q 1, q 2, q 3)}$ is a dummy variable which equals one if firm i's cumulative performance $\left(R O A_{\sum(q 1, q 2, q 3)}\right)$ of the first three quarters in year $\mathrm{t}$ is below that of its peer group. $R O A_{\sum(q 1, q 2, q 3)}$ is calculated using income before extraordinary items in quarter 1 , add that in quarter 2 , quarter 3 , then use the cumulative number divided by average of assets at the beginning of quarter 1 and the end of quarter 3;

$A T A_{i t(q 4)}$ is the abnormal total accrual at the fourth quarter in year t. The definition of abnormal total accrual is explained in the previous tables.

$\operatorname{LogAT}_{i t(q 4)}$ is natural logarithm of asset at fourth quarter of firm $i$ for year $t ; \mathrm{BM}_{i t(q 4)}$ is book value of equity divided by market value of equity at fourth quarter of year $t$ for firm $i ; L E V_{i t(q 4)}$ is total liability divided by total assets at fourth quarter of year $t ; \mathrm{ROA}_{i t(q 4)}$ is income before extraordinary items at fourth quarter of year $t$ in year $t$ divided by the average of total assets of the fourth quarter and beginning of fourth quarter in year $t$; $A T A_{i t} \sum(q 1, q 2, q 3)$ is the abnormal total accrual of the first three quarters at year $\mathrm{t}$, and $A C A_{i t} \sum(q 1, q 2, q 3)$ is abnormal working capital accrual of the first three quarters at year $t$. The definitions of abnormal total accrual and abnormal working capital accrual are explained in the previous tables.

Threshold $1_{i t(q 4)}$, Threshold $2_{i t(q 4)}$ or Threshold $3_{i t(q 4)}$ equal one if firm i just meet and beat threshold 1 , threshold 2 or threshold 3 in the fourth quarter of year $t$. respectively.

\section{Table 21}




\section{Real Earnings Management of Firms Missing First Three Quarters' Cumulative Peer Performance and Achieving Current Year's Peer Performance Benchmark}

\begin{tabular}{|c|c|c|c|c|}
\hline Dependent Variable & \multicolumn{2}{|c|}{$\begin{array}{c}\operatorname{rmUDISX}_{i t(q 4)} \\
\text { Model 1 }\end{array}$} & \multicolumn{2}{|c|}{$\begin{array}{c}\text { rmCASH }_{i t(q 4)} \\
\text { Model } 2\end{array}$} \\
\hline & Coefficients & $p$-value & Coefficients & $p$-value \\
\hline Intercept & 0.0003 & 0.9080 & $-0.0077 * * *$ & 52 \\
\hline Achieve $_{i t}$ & $0.0022 * * *$ & $<.0001$ & $-0.0011 * *$ & 0.0293 \\
\hline $\operatorname{UnPerf}_{i \Sigma(q 1, q 2, q 3)}$ & $0.0022 * * *$ & $<.0001$ & -0.0005 & 0.3151 \\
\hline $\begin{array}{l}\text { Achieve }_{i t} \\
* \operatorname{UnPerf}_{i t \Sigma(q 1, q 2, q 3)}\end{array}$ & $-0.0040 * * *$ & $<.0001$ & $0.0039 * * *$ & 0.0007 \\
\hline $\log _{A} T_{i(q 4)}$ & $-0.0016 * * *$ & $<.0001$ & $0.0009 * * *$ & $<.0001$ \\
\hline$B M_{i(q 4)}$ & $0.0025^{* * *}$ & $<.0001$ & $-0.0008 * * *$ & 0.0055 \\
\hline$L E V_{i(q 4)}$ & $0.0070 * * *$ & $<.0001$ & $-0.0110 * * *$ & $<.0001$ \\
\hline$R O A_{i(q 4)}$ & $0.2406 * * *$ & $<.0001$ & $0.6083 * * *$ & $<.0001$ \\
\hline Threshold $1_{i t(q 4)}$ & $0.0013 * * *$ & 0.0003 & 0.0002 & 0.6098 \\
\hline Threshold $1_{i t(q 4)}$ & 0.0005 & 0.2131 & -0.0004 & 0.3772 \\
\hline Threshold $1_{i t(q 4)}$ & $-0.0007 * *$ & 0.0457 & 0.0004 & 0.3726 \\
\hline$A T A_{i t(q 4)}$ & $-0.4127 * * *$ & $<.0001$ & $-0.6866 * * *$ & $<.0001$ \\
\hline Year Fixed Effects & \multicolumn{2}{|c|}{ Yes } & \multicolumn{2}{|c|}{ Yes } \\
\hline Industry Fixed Effects & \multirow{2}{*}{\multicolumn{2}{|c|}{$\begin{array}{c}\text { Yes } \\
25779\end{array}$}} & \multicolumn{2}{|c|}{ Yes } \\
\hline $\mathrm{N}$ & & & \multirow{2}{*}{\multicolumn{2}{|c|}{$\begin{array}{c}25779 \\
0.5914\end{array}$}} \\
\hline Adjusted $\mathrm{R}^{2}$ & \multicolumn{2}{|c|}{$\begin{array}{l}25779 \\
0.3736\end{array}$} & & \\
\hline
\end{tabular}

$*, * *, * * *$ denotes significance at $10 \%, 5 \%$ and $1 \%$ level respectively.

$\operatorname{rmUDISX}_{i t(q 4)}$ is the unexpected abnormal level of discretionary expenditures at the fourth quarter in year t. The definition of unexpected abnormal level of discretionary expenditures is explained in the previous tables.

$\mathrm{rmCASH}_{i t}$ is the abnormal cash flow from operations at the fourth quarter in year $\mathrm{t}$. The definition of abnormal cash flow from operations is explained in the pervious tables.

$\operatorname{UnPerf}_{i t}(q 1, q 2, q 3)$ is a dummy variable which equals one if firm i's cumulative performance $\left(R O A_{\Sigma(q 1, q 2, q 3)}\right)$ of the first three quarters in year $\mathrm{t}$ is below that of its peer group by no more than 0.05 . In other words, $R O A_{\Sigma(q 1, q 2, q 3)}-\operatorname{Peer}\left(R O A_{\Sigma(q 1, q 2, q 3)}\right)$ is within the range of $(-0.05,0) . R O A_{\sum(q 1, q 2, q 3)}$ is calculated using income before extraordinary items in quarter 1 , add that in quarter 2 , quarter 3 , then use the cumulative number divided by average of assets at the beginning of quarter 1 and the end of quarter 3 ; Achieve $_{i t}$ is a dummy variable and it equals one if firm $i$ 's current year's performance $\left(R O A_{t}\right)$ is above the peer group by no more than 0.05 . In other words, $R O A_{t}-\operatorname{Peer}\left(R O A_{t}\right)$ is within the range of $(0,0.05)$. Achieve $_{i t} * \operatorname{UnPerf}_{i t} \Sigma(q 1, q 2, q 3)$ is the interaction term of $\operatorname{Achieve}_{i t}$ and $\operatorname{UnPerf} f_{i t} \Sigma(q 1, q 2, q 3)$. $A T A_{i t(q 4)}$ is the abnormal total accrual at the fourth quarter in year $t$. The definition of abnormal total accrual is explained in the previous tables. 
$\operatorname{LogAT} T_{i t(q))}$ is natural logarithm of asset at fourth quarter of firm $i$ for year $t ; \mathrm{BM}_{i t(q 4)}$ is book value of equity divided by market value of equity at fourth quarter of year $t$ for firm $i$; $L E V_{i t(q 4)}$ is total liability divided by total assets at fourth quarter of year $t$; $\mathrm{ROA}_{i t(q 4)}$ is income before extraordinary items at fourth quarter of year $t$ in year $t$ divided by the average of total assets of the fourth quarter and beginning of fourth quarter in year $t ; A T A_{i t} \sum(q 1, q 2, q 3)$ is the abnormal total accrual of the first three quarters at year $\mathrm{t}$, and $A C A_{i t} \sum(q 1, q 2, q 3)$ is abnormal working capital accrual of the first three quarters at year $t$. The definitions of abnormal total accrual and abnormal working capital accrual are explained in the previous tables.

Threshold $1_{i t(q 4)}$, Threshold $2_{i t(q 4)}$ or Threshold $3_{i t(q 4)}$ equal one if firm i just meet and beat threshold 1 , threshold 2 or threshold 3 in the fourth quarter of year $t$. respectively. The definition of just meet and beat each threshold is explained in the previous section.

The sample period spans the years 1990 to 2012.

Table 22

Financial Statement Restatement of Firms Achieving Current Year's Peer Performance Benchmark 


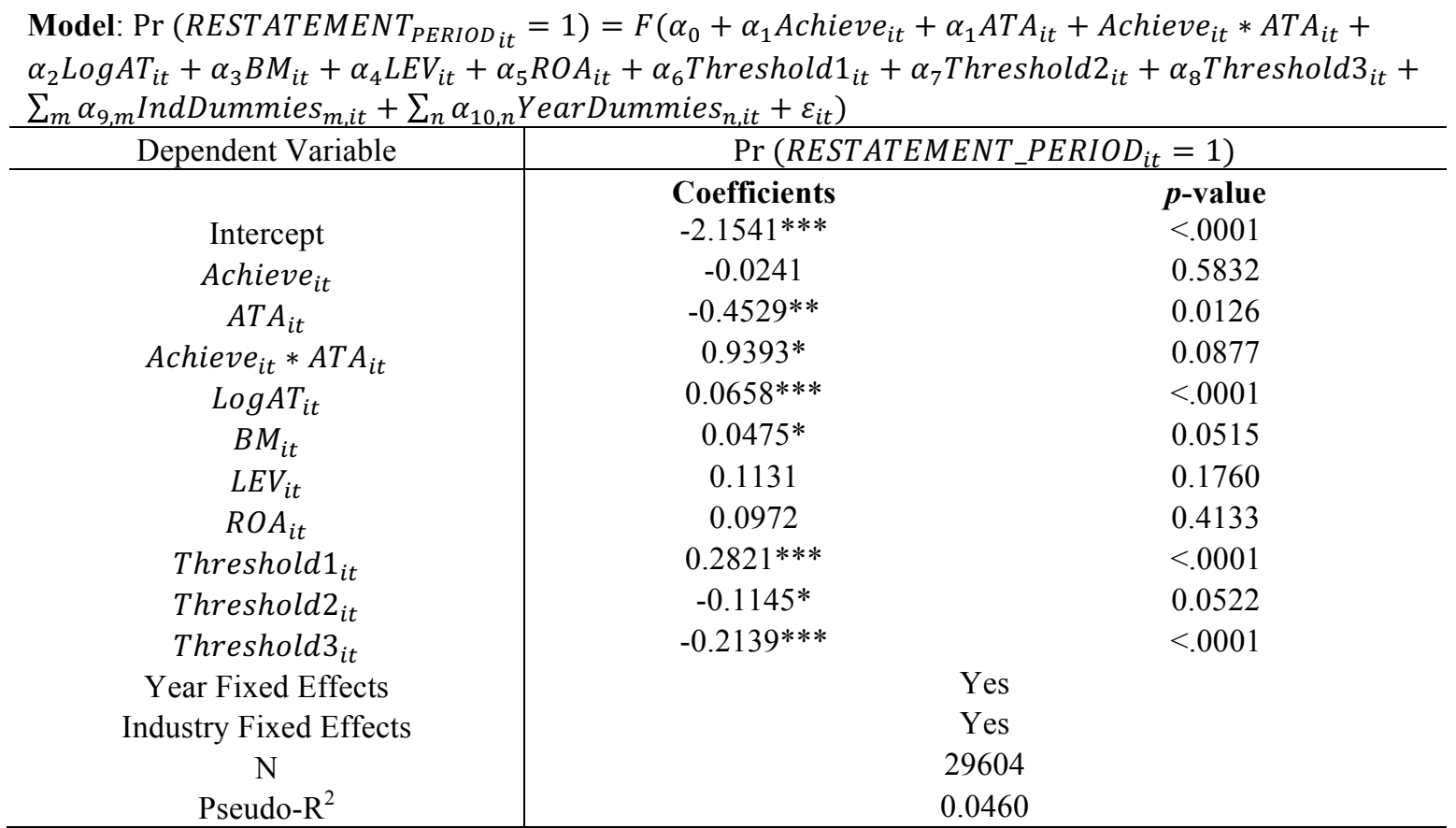

$*, * * * * *$ denotes significance at $10 \%, 5 \%$ and $1 \%$ level respectively.

Restatement_Period $_{i t}$ is an indicator variable which equals to one if firm $i$ is among the misstatement years.

Achieve $_{i t}$ is a dummy variable and it equals one if firm $i$ 's current year's performance $\left(R O A_{t}\right)$ is above the peer group by no more than 0.05 . In other words, $R O A_{t}-\operatorname{Peer}\left(R O A_{t}\right)$ is within the range of $(0,0.05)$. $A T A_{i t}$ is abnormal total accruals, which is the firm-specific residuals derived from following equation estimated cross-sectionally for each industry-year combination:

$\frac{T A_{i t}}{A T_{i t-1}}=\varphi_{0}+\varphi_{1}\left(\frac{1}{A T_{i t-1}}\right)+\varphi_{2}\left(\frac{\Delta R E V_{i t}}{A T_{i t-1}}-\frac{\Delta R E C_{i t}}{A T_{i t-1}}\right)+\varphi_{3}\left(\frac{P P E_{i t}}{A T_{i t-1}}\right)+R O A_{t-1}+\varepsilon_{i t}$

Achieve $_{i t} * A T A_{i t}$ is the interaction term of Achieve $_{i t}$ and $A T A_{i t}$.

$\log \mathrm{AT}_{i t}$ is the natural logarithm of total assets of firm $i$ for year $t . \mathrm{BM}_{i t}$ is the book value of equity divided by market value of equity in year $t$ for firm $i$. ROA $i t$ is return on assets defined as income before

extraordinary items in year $t$ divided by the average of total assets. $L E V_{i t}$ is total liability divided by total assets in year $t$.

Threshold $1_{i t}$ is the indicator variable equal to 1 if the firm avoids losses by a small margin, which is defined as income before extraordinary items scaled by the beginning market value within the range of [0.02]. Threshold $2_{i t}$ is the indicator variable equals to 1 if the firm avoids earnings declines by a small margin, which is defined as change in the income before extraordinary items from year $t-1$ to year $\mathrm{t}$, scaled by the beginning market value within the range of [0.01]. Threshold $3_{i t}$ is an indicator variable equal to 1 if the firm avoids negative earnings surprises by a small margin, which is defined as earnings surprises scaled by beginning price per share within the range of [0.0025].

The sample period spans the years 2000 to 2012 .

Table 23

Financial Statement Restatement of Firms Achieving Current Year's Peer Performance Benchmark 


\begin{tabular}{|c|c|c|}
\hline & & \\
\hline Dependent Variable & $\operatorname{Pr}(R E S$ & $=1)$ \\
\hline Intercept & $\begin{array}{c}\text { Coefficients } \\
-2.1751^{* * *}\end{array}$ & $\begin{array}{l}p \text {-value } \\
<.0001\end{array}$ \\
\hline Achieve $_{i t}$ & -0.0216 & 0.6222 \\
\hline$A C A_{i t}$ & -0.2219 & 0.2633 \\
\hline Achieve $_{i t} * A C A_{i t}$ & $1.3623 * *$ & 0.0192 \\
\hline $\log _{A} T_{i t}$ & $0.0691 * * *$ & $<.0001$ \\
\hline$B M_{i t}$ & $0.0459 *$ & 0.0595 \\
\hline$L E V_{i t}$ & 0.1016 & 0.2227 \\
\hline$R O A_{i t}$ & 0.0277 & 0.8125 \\
\hline Threshold $1_{i t}$ & $0.2826 * * *$ & $<.0001$ \\
\hline Threshold2 $2_{i t}$ & $-0.1132 *$ & 0.0550 \\
\hline Threshold $3_{i t}$ & $-0.2092 * * *$ & $<.0001$ \\
\hline Year Fixed Effects & & \\
\hline Industry Fixed Effects & & \\
\hline $\mathrm{N}$ & & \\
\hline Pseudo-R ${ }^{2}$ & & \\
\hline
\end{tabular}

$*, * *,{ }^{* * *}$ denotes significance at $10 \%, 5 \%$ and $1 \%$ level respectively.

Restatement_Period ${ }_{i t}$ is an indicator variable which equals to one if firm $i$ is among the misstatement years.

Achieve $_{i t}$ is a dummy variable and it equals one if firm $i$ 's current year's performance $\left(R O A_{t}\right)$ is above the peer group by no more than 0.05 . In other words, $R O A_{t}-\operatorname{Peer}\left(R O A_{t}\right)$ is within the range of $(0,0.05)$. $A C A_{i t}$ is abnormal current accruals, which is defined as the firm specific residuals from the following equation estimated cross-sectionally for each year-industry combination.

$\frac{C A_{i t}}{A T_{i t-1}}=\varphi_{0}+\varphi_{1}\left(\frac{1}{A T_{i t-1}}\right)+\varphi_{2}\left(\frac{\Delta R E V_{i t}}{A T_{i t-1}}-\frac{\Delta R E C_{i t}}{A T_{i t-1}}\right)+R O A_{t-1}+\varepsilon_{i t}$

Achieve $_{i t} * A C A_{i t}$ is the interaction term of Achieve $i t$ and $A C A_{i t}$.

$\operatorname{LogAT} T_{i t}$ is the natural logarithm of total assets of firm $i$ for year $t . \mathrm{BM}_{i t}$ is the book value of equity divided by market value of equity in year $t$ for firm $i$. ROA $i t$ is return on assets defined as income before

extraordinary items in year $t$ divided by the average of total assets. $L E V_{i t}$ is total liability divided by total assets in year $t$.

Threshold $1_{i t}$ is the indicator variable equal to 1 if the firm avoids losses by a small margin, which is defined as income before extraordinary items scaled by the beginning market value within the range of [0.02]. Threshold $2_{i t}$ is the indicator variable equals to 1 if the firm avoids earnings declines by a small margin, which is defined as change in the income before extraordinary items from year $t-1$ to year $\mathrm{t}$, scaled by the beginning market value within the range of [0.01]. Threshold $3_{i t}$ is an indicator variable equal to 1 if the firm avoids negative earnings surprises by a small margin, which is defined as earnings surprises scaled by beginning price per share within the range of [0.0025].

The sample period spans the years 2000 to 2012 .

Table 24 


\section{Financial Statement Restatement of Firms Achieving Current Year's and Missing Prior Year's Peer Performance Benchmark}

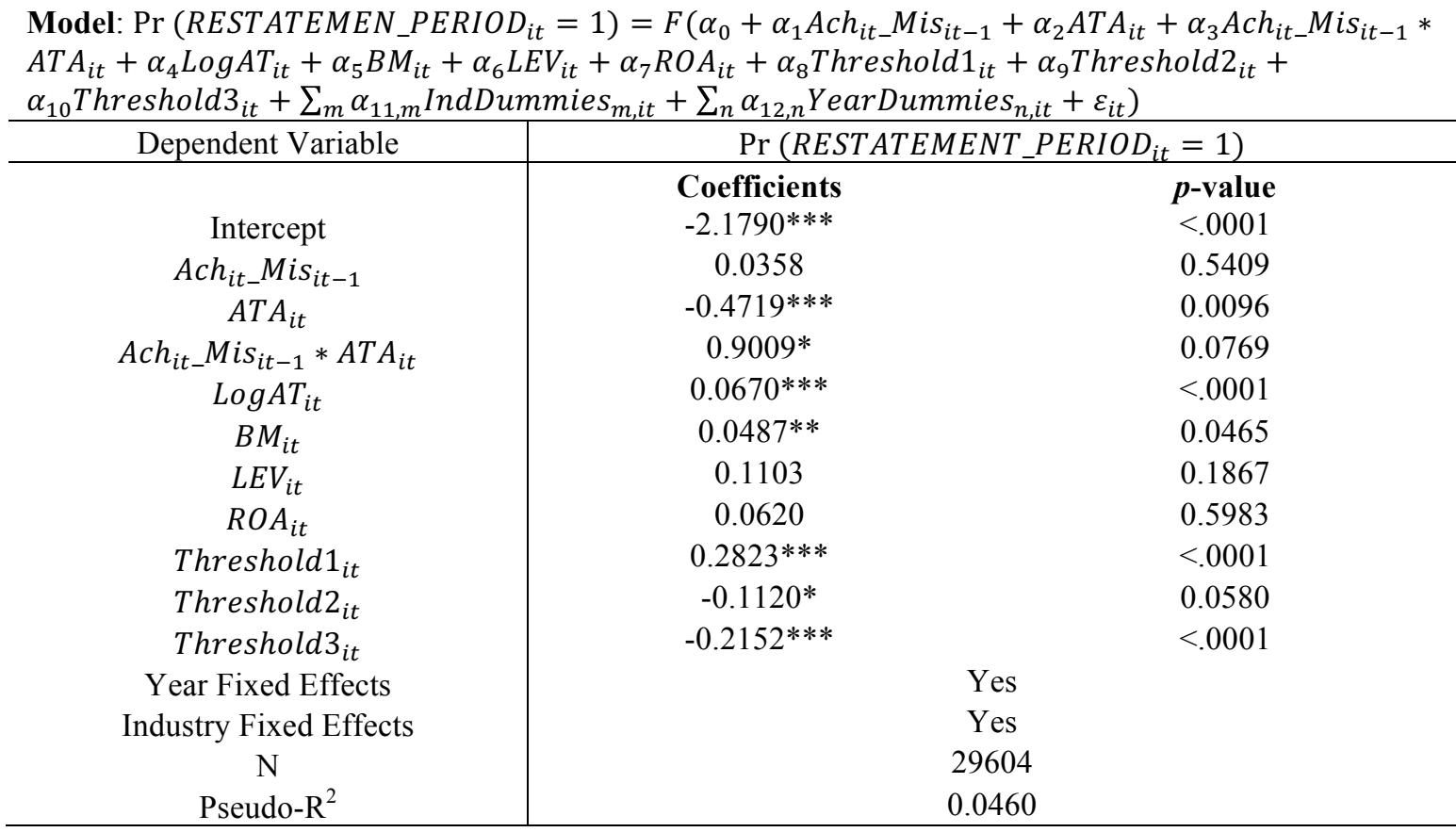

$*, * *, * * *$ denotes significance at $10 \%, 5 \%$ and $1 \%$ level respectively.

Restatement_Period ${ }_{i t}$ is an indicator variable which equals to one if firm $i$ is among the misstatement years.

$A c h_{i t} M_{i t-1}$ is a dummy variable equals to one if two criteria are met. 1) Firm $i$ 's current year's performance $\left(R O A_{t}\right)$ is above the peer group, 2) Firm $i$ 's prior year's performance $\left(R O A_{t-1}\right)$ is below that of its peer group.

$A T A_{i t}$ is abnormal total accruals, which is the firm-specific residuals derived from following equation estimated cross-sectionally for each industry-year combination:

$\frac{T A_{i t}}{A T_{i t-1}}=\varphi_{0}+\varphi_{1}\left(\frac{1}{A T_{i t-1}}\right)+\varphi_{2}\left(\frac{\Delta R E V_{i t}}{A T_{i t-1}}-\frac{\Delta R E C_{i t}}{A T_{i t-1}}\right)+\varphi_{3}\left(\frac{P P E_{i t}}{A T_{i t-1}}\right)+R O A_{t-1}+\varepsilon_{i t}$ Ach $_{i t}$ Mis $_{i t-1} * A T A_{i t}$ is the interaction term of $A c h_{i t} M i s_{i t-1}$ and $A T A_{i t}$.

$\operatorname{LogAT}_{i t}$ is the natural logarithm of total assets of firm $i$ for year $t . \mathrm{BM}_{i t}$ is the book value of equity divided by market value of equity in year $t$ for firm $i$. $\mathrm{ROA}_{i t}$ is return on assets defined as income before extraordinary items in year $t$ divided by the average of total assets. $L E V_{i t}$ is total liability divided by total assets in year $t$.

Threshold $1_{i t}$ is the indicator variable equal to 1 if the firm avoids losses by a small margin, which is defined as income before extraordinary items scaled by the beginning market value within the range of [0.02]. Threshold $2_{i t}$ is the indicator variable equals to 1 if the firm avoids earnings declines by a small margin, which is defined as change in the income before extraordinary items from year $t-1$ to year $\mathrm{t}$, scaled by the beginning market value within the range of [0.01]. Threshold $3_{i t}$ is an indicator variable equal to 1 if the firm avoids negative earnings surprises by a small margin, which is defined as earnings surprises scaled by beginning price per share within the range of [0.0025].

The sample period spans the years 2000 to 2012 .

Table 25 


\section{Financial Statement Restatement of Firms Achieving Current Year's and Missing Prior Year's Peer Performance Benchmark}

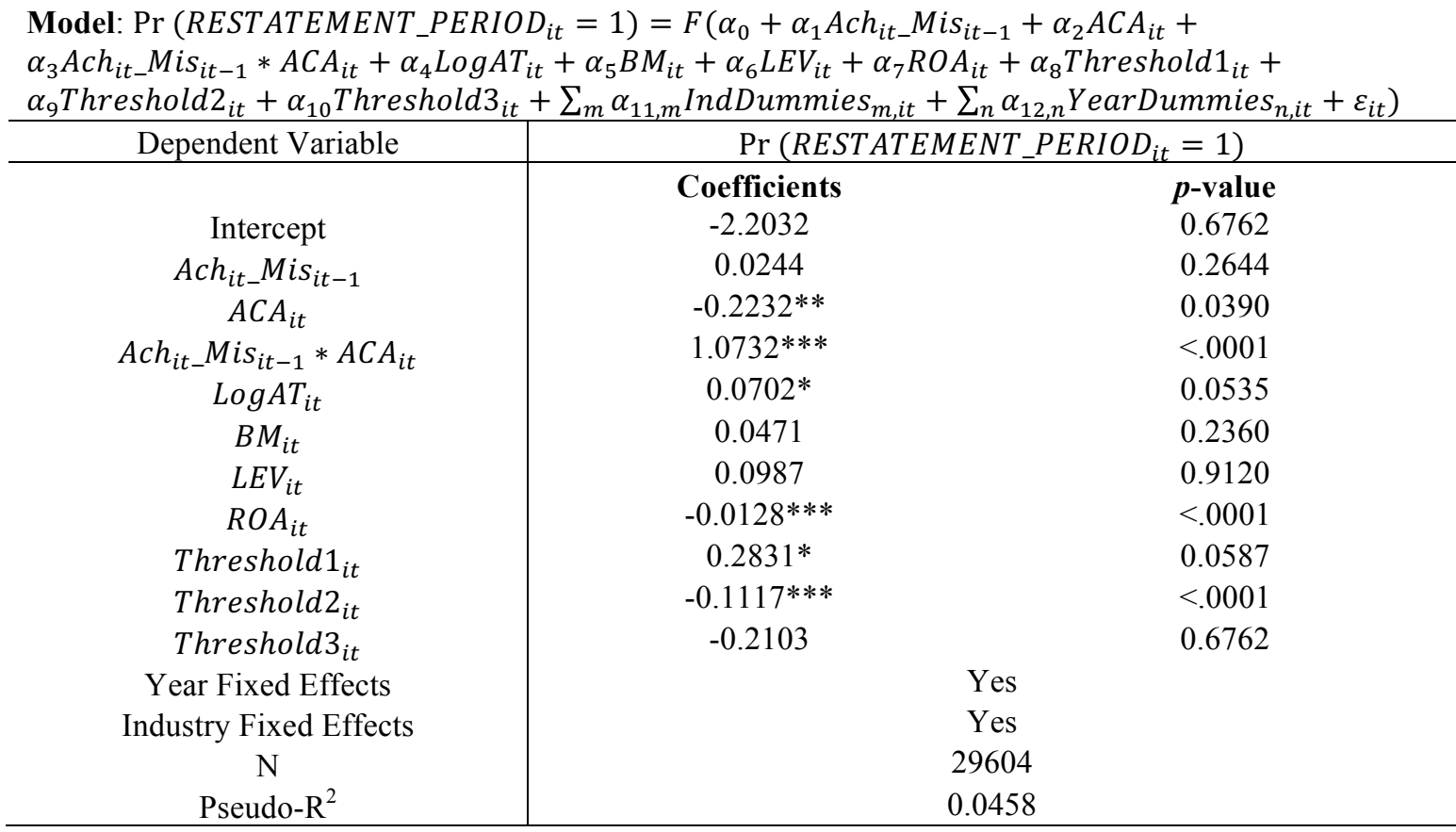

$*, * *, * * *$ denotes significance at $10 \%, 5 \%$ and $1 \%$ level respectively.

Restatement_Period ${ }_{i t}$ is an indicator variable which equals to one if firm $i$ is among the misstatement years.

Ach $_{i t}$ Mis $_{i t-1}$ a dummy variable equals to one if two criteria are met. 1) Firm $i$ 's current year's performance $\left(R O A_{t}\right)$ is above the peer group, 2) Firm $i$ 's prior year's performance $\left(R O A_{t-1}\right)$ is below that of its peer group.

$A C A_{i t}$ is abnormal current accruals, which is defined as the firm specific residuals from the following equation estimated cross-sectionally for each year-industry combination.

$\frac{C A_{i t}}{A T_{i t-1}}=\varphi_{0}+\varphi_{1}\left(\frac{1}{A T_{i t-1}}\right)+\varphi_{2}\left(\frac{\Delta R E V_{i t}}{A T_{i t-1}}-\frac{\Delta R E C_{i t}}{A T_{i t-1}}\right)+R O A_{t-1}+\varepsilon_{i t}$

Ach $_{i t}$ Mis $_{i t-1} * A C A_{i t}$ is the interaction term of $A c h_{i t} M i s_{i t-1}$ and $A C A_{i t}$.

$\operatorname{LogAT}_{i t}$ is the natural logarithm of total assets of firm $i$ for year $t . \mathrm{BM}_{i t}$ is the book value of equity divided by market value of equity in year $t$ for firm $i$. $\mathrm{ROA}_{i t}$ is return on assets defined as income before

extraordinary items in year $t$ divided by the average of total assets. $L E V_{i t}$ is total liability divided by total assets in year $t$.

Threshold $1_{i t}$ is the indicator variable equal to 1 if the firm avoids losses by a small margin, which is defined as income before extraordinary items scaled by the beginning market value within the range of [0.02]. Threshold $2_{i t}$ is the indicator variable equals to 1 if the firm avoids earnings declines by a small margin, which is defined as change in the income before extraordinary items from year $t-1$ to year $\mathrm{t}$, scaled by the beginning market value within the range of [0.01]. Threshold $3_{i t}$ is an indicator variable equal to 1 if the firm avoids negative earnings surprises by a small margin, which is defined as earnings surprises scaled by beginning price per share within the range of [0.0025].

The sample period spans the years 2000 to 2012 .

Table 26 


\section{Financial Statement Restatement of Firms Achieving Current Year's and Missing Prior two Year's Peer Performance Benchmark}

\begin{tabular}{|c|c|c|}
\hline Dependent Variable & $\operatorname{Pr}(R E S$ & \\
\hline & Coefficients & $p$-value \\
\hline Intercept & $-2.1821 * * *$ & $<.0001$ \\
\hline$A c h_{i t} M i s_{i \mu(t-1, t-2)}$ & 0.0307 & 0.5812 \\
\hline$A T A_{i t}$ & $-0.4774 * * *$ & 0.0092 \\
\hline$A c h_{i t-} \operatorname{Mis}_{i \mu(t-1, t-2)} * A T A_{i t}$ & $0.8705^{*}$ & 0.0740 \\
\hline $\log _{A} T_{i t}$ & $0.0670 * * *$ & $<.0001$ \\
\hline$B M_{i t}$ & $0.0488 * *$ & 0.0460 \\
\hline$L E V_{i t}$ & 0.1114 & 0.1824 \\
\hline$R O A_{i t}$ & 0.0627 & 0.5957 \\
\hline Threshold $1_{i t}$ & $0.2828 * * *$ & $<.0001$ \\
\hline Threshold2 $i t$ & $-0.1124 *$ & 0.0570 \\
\hline Threshold $3_{i t}$ & $-0.2146^{* * *}$ & $<.0001$ \\
\hline Year Fixed Effects & & \\
\hline Industry Fixed Effects & & \\
\hline $\mathrm{N}$ & & \\
\hline Pseudo- $\mathrm{R}^{2}$ & & \\
\hline
\end{tabular}

$* * *, * * *$ denotes significance at $10 \%, 5 \%$ and $1 \%$ level respectively.

Restatement_Period ${ }_{i t}$ is an indicator variable which equals to one if firm $i$ is among the misstatement years.

$A c h_{i t} M_{i \mu(t-1, t-2)}$ is a dummy variable equals to one if two criteria are met. 1) Firm $i$ 's current year's performance $\left(R O A_{t}\right)$ is above the peer group, 2) Firm $i$ 's average performance $\left(R O A_{\mu(t-1, t-2)}\right)$ of the past two years is below that of its peer group. $R O A_{\mu(t-1, t-2)}$ is calculated using $\frac{R O A_{t-2}+R O A_{t-1}}{2}$.

$A T A_{i t}$ is abnormal total accruals, which is the firm-specific residuals derived from following equation estimated cross-sectionally for each industry-year combination:

$\frac{T A_{i t}}{A T_{i t-1}}=\varphi_{0}+\varphi_{1}\left(\frac{1}{A T_{i t-1}}\right)+\varphi_{2}\left(\frac{\Delta R E V_{i t}}{A T_{i t-1}}-\frac{\Delta R E C_{i t}}{A T_{i t-1}}\right)+\varphi_{3}\left(\frac{P P E_{i t}}{A T_{i t-1}}\right)+R O A_{t-1}+\varepsilon_{i t}$ Ach $_{i t}$ Mis $_{i \mu(t-1, t-2)} * A T A_{i t}$ is the interaction term of $A c h_{i t} M i s_{i \mu(t-1, t-2)}$ and $A T A_{i t}$.

$\operatorname{LogAT}_{i t}$ is the natural logarithm of total assets of firm $i$ for year $t . \mathrm{BM}_{i t}$ is the book value of equity divided by market value of equity in year $t$ for firm $i$. ROA $i t$ is return on assets defined as income before extraordinary items in year $t$ divided by the average of total assets. $L E V_{i t}$ is total liability divided by total assets in year $t$.

Threshold $1_{i t}$ is the indicator variable equal to 1 if the firm avoids losses by a small margin, which is defined as income before extraordinary items scaled by the beginning market value within the range of [0.02]. Threshold $2_{i t}$ is the indicator variable equals to 1 if the firm avoids earnings declines by a small margin, which is defined as change in the income before extraordinary items from year $t$ - 1 to year $\mathrm{t}$, scaled by the beginning market value within the range of [0.01]. Threshold $3_{i t}$ is an indicator variable equal to 1 if the firm avoids negative earnings surprises by a small margin, which is defined as earnings surprises scaled by beginning price per share within the range of [0.0025].

The sample period spans the years 2000 to 2012 .

Table 27 


\section{Financial Statement Restatement of Firms Achieving Current Year's and Missing Prior two Year's Peer Performance Benchmark}

\begin{tabular}{|c|c|c|}
\hline Dependent Variable & \multicolumn{2}{|c|}{$\operatorname{Pr}\left(\right.$ REST ATEMENT_PERIOD $\left.D_{i t}=1\right)$} \\
\hline & Coefficients & $p$-value \\
\hline Intercept & $-2.2047 * * *$ & $<.0001$ \\
\hline$A c h_{i t}{ }_{-} \operatorname{Mis}_{i \mu(t-1, t-2)}$ & 0.0215 & 0.6996 \\
\hline$A C A_{i t}$ & -0.2263 & 0.2616 \\
\hline$A c h_{i t} M i s_{i \mu(t-1, t-2)} * A C A_{i t}$ & $0.9979 * *$ & 0.0452 \\
\hline $\log A T_{i t}$ & $0.0703 * * *$ & $<.0001$ \\
\hline$B M_{i t}$ & $0.0473 *$ & 0.0530 \\
\hline$L E V_{i t}$ & 0.1003 & 0.2287 \\
\hline$R O A_{i t}$ & -0.0128 & 0.9123 \\
\hline Threshold $1_{i t}$ & $0.2834 * * *$ & $<.0001$ \\
\hline Threshold $2_{i t}$ & $-0.1118 *$ & 0.0584 \\
\hline Threshold $3_{i t}$ & $-0.2098^{* * *}$ & $<.0001$ \\
\hline Year Fixed Effects & \multicolumn{2}{|c|}{ Yes } \\
\hline Industry Fixed Effects & \multicolumn{2}{|c|}{ Yes } \\
\hline $\mathrm{N}$ & \multicolumn{2}{|c|}{29604} \\
\hline Pseudo- $\mathrm{R}^{2}$ & \multicolumn{2}{|c|}{0.0458} \\
\hline
\end{tabular}

$* * *, * * *$ denotes significance at $10 \%, 5 \%$ and $1 \%$ level respectively.

Restatement_Period ${ }_{i t}$ is an indicator variable which equals to one if firm $i$ is among the misstatement years.

$A c h_{i t} M_{i \mu(t-1, t-2)}$ is a dummy variable equals to one if two criteria are met. 1) Firm $i$ 's current year's performance $\left(R O A_{t}\right)$ is above the peer group, 2) Firm $i$ 's average performance $\left(R O A_{\mu(t-1, t-2)}\right)$ of the past two years is below that of its peer group. $R O A_{\mu(t-1, t-2)}$ is calculated using $\frac{R O A_{t-2}+R O A_{t-1}}{2}$.

$A C A_{i t}$ is abnormal current accruals, which is defined as the firm specific residuals from the following equation estimated cross-sectionally for each year-industry combination.

$\frac{C A_{i t}}{A T_{i t-1}}=\varphi_{0}+\varphi_{1}\left(\frac{1}{A T_{i t-1}}\right)+\varphi_{2}\left(\frac{\Delta R E V_{i t}}{A T_{i t-1}}-\frac{\Delta R E C_{i t}}{A T_{i t-1}}\right)+R O A_{t-1}+\varepsilon_{i t}$

Ach $_{i t}$ Mis $_{i \mu(t-1, t-2)} * A C A_{i t}$ is the interaction term of $A c h_{i t_{-}} M i s_{i \mu(t-1, t-2)}$ and $A C A_{i t}$.

$\operatorname{LogAT} i t$ is the natural logarithm of total assets of firm $i$ for year $t . \mathrm{BM}_{i t}$ is the book value of equity divided by market value of equity in year $t$ for firm $i$. ROA $i t$ is return on assets defined as income before extraordinary items in year $t$ divided by the average of total assets. $L E V_{i t}$ is total liability divided by total assets in year $t$.

Threshold $1_{i t}$ is the indicator variable equal to 1 if the firm avoids losses by a small margin, which is defined as income before extraordinary items scaled by the beginning market value within the range of [0.02]. Threshold $2_{i t}$ is the indicator variable equals to 1 if the firm avoids earnings declines by a small margin, which is defined as change in the income before extraordinary items from year $t-1$ to year $\mathrm{t}$, scaled by the beginning market value within the range of [0.01]. Threshold $3_{i t}$ is an indicator variable equal to 1 if the firm avoids negative earnings surprises by a small margin, which is defined as earnings surprises scaled by beginning price per share within the range of [0.0025].

The sample period spans the years 2000 to 2012 .

Table 28 


\section{Financial Statement Restatement of Firms Achieving Current Year's Peer Performance Benchmark and Missing Current Year's Expected Peer Performance Benchmark}

\begin{tabular}{|c|c|c|}
\hline Dependent Variable & \multicolumn{2}{|c|}{$\operatorname{Pr}\left(\right.$ REST ATEMENT_PERIOD $\left.D_{i t}=1\right)$} \\
\hline & Coefficients & $p$-value \\
\hline Intercept & $-2.1567 * * *$ & $<.0001$ \\
\hline Ach $_{i t \_} E M i s_{i t}$ & -0.1031 & 0.1169 \\
\hline$A T A_{i t}$ & $-0.3445^{*}$ & 0.0523 \\
\hline Ach $_{i t_{-}} E M i s_{i t} * A T A_{i t}$ & 0.0211 & 0.9765 \\
\hline $\log _{i t}$ & $0.0658 * * *$ & $<.0001$ \\
\hline$B M_{i t}$ & $0.0479 * *$ & 0.0496 \\
\hline$L E V_{i t}$ & 0.1163 & 0.1637 \\
\hline$R O A_{i t}$ & 0.0753 & 0.5212 \\
\hline Threshold $1_{i t}$ & $0.2786^{* * *}$ & $<.0001$ \\
\hline Threshold2 ${ }_{i t}$ & $-0.1176^{* *}$ & 0.0460 \\
\hline Threshold $3_{i t}$ & $-0.2116^{* * *}$ & $<.0001$ \\
\hline Year Fixed Effects & \multicolumn{2}{|c|}{ Yes } \\
\hline Industry Fixed Effects & \multicolumn{2}{|c|}{ Yes } \\
\hline $\mathrm{N}$ & \multicolumn{2}{|c|}{29604} \\
\hline Pseudo- $\mathrm{R}^{2}$ & \multicolumn{2}{|c|}{0.0459} \\
\hline
\end{tabular}

$*, * *, * * *$ denotes significance at $10 \%, 5 \%$ and $1 \%$ level respectively.

Restatement_Period $_{i t}$ is an indicator variable which equals to one if firm $i$ is among the misstatement years.

$A c h_{i t} E M i s_{i t}$ is a dummy variable equals to one if two criteria are met. 1) Firm $i$ 's current year's performance $\left(R O A_{t}\right)$ is above the peer group, 2) Firm $i$ 's expected performance Forecasted_EPS $S_{t}$ at year $t$ is below its peer group's expected performance for year $t$. Firm i's expected performance

Forecasted_EPS $S_{t}$ is calculated using analysts' consensus forecasted EPS scaled by scaled by assets per share at the beginning of the fiscal year. Consensus analyst forecasted EPS are the mean analysts' forecasts for the next period. $A T A_{i t}$ is abnormal total accruals, which is the firm-specific residuals derived from following equation estimated cross-sectionally for each industry-year combination:

$\frac{T A_{i t}}{A T_{i t-1}}=\varphi_{0}+\varphi_{1}\left(\frac{1}{A T_{i t-1}}\right)+\varphi_{2}\left(\frac{\Delta R E V_{i t}}{A T_{i t-1}}-\frac{\Delta R E C_{i t}}{A T_{i t-1}}\right)+\varphi_{3}\left(\frac{P P E_{i t}}{A T_{i t-1}}\right)+R O A_{t-1}+\varepsilon_{i t}$

Ach $_{i t_{-}} E M i s_{i t} * A T A_{i t}$ is the interaction term of $A c h_{i t} E M i s_{i t}$ and $A T A_{i t}$.

$\operatorname{LogAT} T_{i t}$ is the natural logarithm of total assets of firm $i$ for year $t . \mathrm{BM}_{i t}$ is the book value of equity divided by market value of equity in year $t$ for firm $i$. $\mathrm{ROA}_{i t}$ is return on assets defined as income before extraordinary items in year $t$ divided by the average of total assets. $L E V_{i t}$ is total liability divided by total assets in year $t$.

Threshold $1_{i t}$ is the indicator variable equal to 1 if the firm avoids losses by a small margin, which is defined as income before extraordinary items scaled by the beginning market value within the range of [0.02]. Threshold $2_{i t}$ is the indicator variable equals to 1 if the firm avoids earnings declines by a small margin, which is defined as change in the income before extraordinary items from year $t$ - 1 to year $\mathrm{t}$, scaled by the beginning market value within the range of [0.01]. Threshold $3_{i t}$ is an indicator variable equal to 1 if the firm avoids negative earnings surprises by a small margin, which is defined as earnings surprises scaled by beginning price per share within the range of [0.0025].

The sample period spans the years 2000 to 2012 .

Table 29 


\section{Financial Statement Restatement of Firms Achieving Current Year's Peer Performance Benchmark and Missing Current Year's Expected Peer Performance Benchmark}

\begin{tabular}{|c|c|c|}
\hline Dependent Variable & \multicolumn{2}{|c|}{$\operatorname{Pr}\left(\right.$ RESTATEMENT_PERIOD $\left.{ }_{i t}=1\right)$} \\
\hline Intercent & Coefficients & $\begin{array}{c}\boldsymbol{p} \text {-value } \\
<0001\end{array}$ \\
\hline$A c h_{i t} E M i s_{i t}$ & $-0.1084 *$ & 0.0993 \\
\hline$A C A_{i t}$ & -0.0712 & 0.7136 \\
\hline$A c h_{i t} E M i s_{i t} * A C A_{i t}$ & 0.1872 & 0.7985 \\
\hline $\log _{A} A T_{i t}$ & $0.0690 * * *$ & $<.0001$ \\
\hline$B M_{i t}$ & $0.0464 *$ & 0.0571 \\
\hline$L E V_{i t}$ & 0.1060 & 0.2028 \\
\hline$R O A_{i t}$ & 0.0032 & 0.9782 \\
\hline Threshold $1_{i t}$ & $0.2797 * * *$ & $<.0001$ \\
\hline Threshold $2_{i t}$ & $-0.1168 * *$ & 0.0475 \\
\hline Threshold $3_{i t}$ & $-0.2068 * * *$ & $<.0001$ \\
\hline Year Fixed Effects & \multicolumn{2}{|c|}{ Yes } \\
\hline Industry Fixed Effects & \multicolumn{2}{|c|}{ Yes } \\
\hline $\mathrm{N}$ & \multicolumn{2}{|c|}{29604} \\
\hline Pseudo- $\mathrm{R}^{2}$ & \multicolumn{2}{|c|}{0.0457} \\
\hline
\end{tabular}

$*, * *, * * *$ denotes significance at $10 \%, 5 \%$ and $1 \%$ level respectively.

Restatement_Period ${ }_{i t}$ is an indicator variable which equals to one if firm $i$ is among the misstatement years.

$A c h_{i t} E M i s_{i t}$ is a dummy variable equals to one if two criteria are met. 1) Firm $i$ 's current year's performance $\left(R O A_{t}\right)$ is above the peer group, 2) Firm $i$ 's expected performance Forecasted_EPS $S_{t}$ at year $t$ is below its peer group's expected performance for year $t$. Firm i's expected performance

Forecasted_EPS $S_{t}$ is calculated using analysts' consensus forecasted EPS scaled by scaled by assets per share at the beginning of the fiscal year. Consensus analyst forecasted EPS are the mean analysts' forecasts for the next period. $A T A_{i t}$ is abnormal total accruals, which is the firm-specific residuals derived from following equation estimated cross-sectionally for each industry-year combination:

$\frac{T A_{i t}}{A T_{i t-1}}=\varphi_{0}+\varphi_{1}\left(\frac{1}{A T_{i t-1}}\right)+\varphi_{2}\left(\frac{\Delta R E V_{i t}}{A T_{i t-1}}-\frac{\Delta R E C_{i t}}{A T_{i t-1}}\right)+\varphi_{3}\left(\frac{P P E_{i t}}{A T_{i t-1}}\right)+R O A_{t-1}+\varepsilon_{i t}$

Ach $_{i t_{-}} E M i s_{i t} * A T A_{i t}$ is the interaction term of $A c h_{i t} E M i s_{i t}$ and $A T A_{i t}$.

$\operatorname{LogAT} i t$ is the natural logarithm of total assets of firm $i$ for year $t . \mathrm{BM}_{i t}$ is the book value of equity divided by market value of equity in year $t$ for firm $i$. ROA $i t$ is return on assets defined as income before

extraordinary items in year $t$ divided by the average of total assets. $L E V_{i t}$ is total liability divided by total assets in year $t$.

Threshold $1_{i t}$ is the indicator variable equal to 1 if the firm avoids losses by a small margin, which is defined as income before extraordinary items scaled by the beginning market value within the range of [0.02]. Threshold $2_{i t}$ is the indicator variable equals to 1 if the firm avoids earnings declines by a small margin, which is defined as change in the income before extraordinary items from year $t$ - 1 to year $\mathrm{t}$, scaled by the beginning market value within the range of [0.01]. Threshold $3_{i t}$ is an indicator variable equal to 1 if the firm avoids negative earnings surprises by a small margin, which is defined as earnings surprises scaled by beginning price per share within the range of [0.0025].

The sample period spans the years 2000 to 2012 .

Table 30 


\section{Financial Statement Restatement of Firms Missing First Three Quarters' Cumulative Peer Performance Benchmark}

$$
\begin{aligned}
& \text { Model:Pr }\left(R E S T A T E M E N T_{-} P E R I O D_{i t(q 4)}=1\right)=F\left(\alpha_{0}+\alpha_{1} A_{c h} h_{M i s_{i t}(q 1, q 2, q 3)}+\alpha_{2} A T A_{i t(q 4)}+\right. \\
& \alpha_{3} A c h_{M i s_{i t \sum(q 1, q 2, q 3)}} * A T A_{i t(q 4)}+\alpha_{4} \log _{\text {it }} T_{i t(q 4)}+\alpha_{5} B M_{i t(q 4)}+\alpha_{6} L E V_{i t(q 4)}+\alpha_{7} R O A_{i t(q 4)}+
\end{aligned}
$$

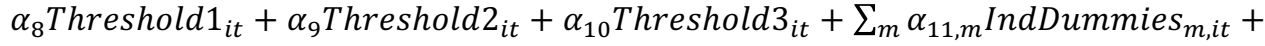

\begin{tabular}{|c|c|c|}
\hline Dependent Variable & \multicolumn{2}{|c|}{$\operatorname{Pr}\left(\right.$ REST ATEMENT_PERIOD $\left.{ }_{i t}=1\right)$} \\
\hline Intercept & $\begin{array}{l}\text { Coefficients } \\
-2.2227^{* * *}\end{array}$ & $\begin{array}{c}p \text {-value } \\
<.0001\end{array}$ \\
\hline$A c h_{M i s_{i t}(q 1, q 2, q 3)}$ & 0.1955 & 0.1317 \\
\hline$A T A_{i t(q 4)}$ & $-1.2278 * *$ & 0.0283 \\
\hline $\operatorname{Ach}_{M i s_{i t \sum(q 1, q 2, q 3)}} * A T A_{i t(q 4)}$ & $3.8939 * *$ & 0.0268 \\
\hline $\log A T_{i q 4}$ & 0.0247 & 0.1561 \\
\hline$B M_{i q 4}$ & 0.0263 & 0.3824 \\
\hline$L E V_{i q 4}$ & 0.1761 & 0.1274 \\
\hline$R O A_{i q 4}$ & $1.1267 * *$ & 0.0289 \\
\hline Threshold 1 & -0.0752 & 0.2191 \\
\hline Threshold 2 & $-0.2683 * * *$ & $<.0001$ \\
\hline Threshold3 & $-0.1995 * * *$ & 0.0009 \\
\hline Year Fixed Effects & \multicolumn{2}{|c|}{ Yes } \\
\hline Industry Fixed Effects & \multicolumn{2}{|c|}{ Yes } \\
\hline $\mathrm{N}$ & \multicolumn{2}{|c|}{29604} \\
\hline Pseudo- $\mathrm{R}^{2}$ & \multicolumn{2}{|c|}{0.0375} \\
\hline
\end{tabular}

$$
\begin{aligned}
& \left.\sum_{n} \alpha_{12, n} \text { YearDummies }_{n, i t}+\varepsilon_{i t}\right)
\end{aligned}
$$

$* * *, * * *$ denotes significance at $10 \%, 5 \%$ and $1 \%$ level respectively.

Restatement_Period $i t$ is an indicator variable which equals to one if the quarter four of firm $i$ is among the misstatement quarters.

$A c h_{M i s_{i t}(q 1, q 2, q 3)}$ is a dummy variable equals to one if two criteria are met. 1) Firm $i$ 's current year's performance $\left(R O A_{t}\right)$ is above the peer group, 2) Firm i's cumulative performance $\left(R O A_{\sum(q 1, q 2, q 3)}\right)$ of the first three quarters in year $\mathrm{t}$ is below that of its peer group. $R O A_{\sum(q 1, q 2, q 3)}$ is calculated using income before extraordinary items in quarter 1 , add that in quarter 2 , quarter 3 , then use the cumulative number divided by average of assets at the beginning of quarter 1 and the end of quarter 3 ;

$A T A_{i t(q 4)}$ is abnormal total accruals of fourth quarter, which is the firm-specific residuals derived from following equation estimated cross-sectionally for each industry-year-quarter combination:

$\frac{T A_{i t}}{A T_{i t-1}}=\varphi_{0}+\varphi_{1}\left(\frac{1}{A T_{i t-1}}\right)+\varphi_{2}\left(\frac{\Delta R E V_{i t}}{A T_{i t-1}}-\frac{\Delta R E C_{i t}}{A T_{i t-1}}\right)+\varphi_{3}\left(\frac{P P E_{i t}}{A T_{i t-1}}\right)+R O A_{t-1}+\varepsilon_{i t}$ $A c h_{M i s_{i t}(q 1, q 2, q 3)} * A T A_{i t(q 4)}$ is the interaction term of $A c h_{M i s_{i t}(q 1, q 2, q 3)}$ and $A T A_{i t}$.

$\operatorname{LogAT}_{i t(q 4)}$ is natural logarithm of asset at fourth quarter of firm $i$ for year $t ; \mathrm{BM}_{i t(q 4)}$ is book value of equity divided by market value of equity at fourth quarter of year $t$ for firm $i$; $L E V_{i t(q 4)}$ is total liability divided by total assets at fourth quarter of year $t$; $\mathrm{ROA}_{i t(q 4)}$ is income before extraordinary items at fourth quarter of year $t$ in year $t$ divided by the average of total assets of the fourth quarter and beginning of fourth quarter in

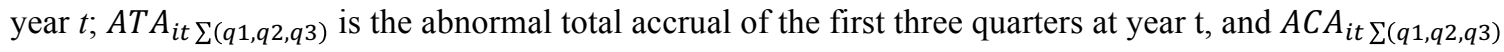
is abnormal working capital accrual of the first three quarters at year $t$. The definitions of abnormal total accrual and abnormal working capital accrual are explained in the previous tables.

Threshold $1_{i t(q 4)}$, Threshold $2_{i t(q 4)}$ or Threshold $3_{i t(q 4)}$ equal one if firm i just meet and beat threshold 1 , threshold 2 or threshold 3 in the fourth quarter of year $t$. respectively.

Table 31 


\section{Financial Statement Restatement of Firms Missing First Three Quarters' Cumulative Peer Performance Benchmark}

$$
\begin{aligned}
& \text { Model:Pr }\left(R E S T A T E M E N T_{-} P E R I O D_{i t(q 4)}=1\right)=F\left(\alpha_{0}+\alpha_{1} A_{c h} h_{M i s_{i t}(q 1, q 2, q 3)}+\alpha_{2} A C A_{i t(q 4)}+\right. \\
& \alpha_{3} A c h_{M i s_{i t \sum(q 1, q 2, q 3)}} * A C A_{i t(q 4)}+\alpha_{4} \log _{i t(q 4)}+\alpha_{5} B M_{i t(q 4)}+\alpha_{6} L E V_{i t(q 4)}+\alpha_{7} R O A_{i t(q 4)}+
\end{aligned}
$$

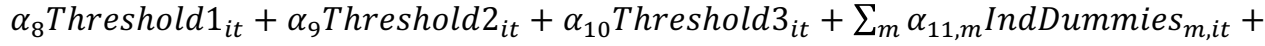

\begin{tabular}{|c|c|c|}
\hline Dependent Variable & \multicolumn{2}{|c|}{$\operatorname{Pr}\left(\right.$ REST ATEMENT_PERIOD $\left.{ }_{i t}=1\right)$} \\
\hline Intercept & $\begin{array}{c}\text { Coefficients } \\
-2.2269^{* * *}\end{array}$ & $\begin{array}{c}p \text {-value } \\
<.0001\end{array}$ \\
\hline$A c h_{M i s_{i t}(q 1, q 2, q 3)}$ & $0.2325^{*}$ & 0.0662 \\
\hline$A C A_{i t(q 4)}$ & $-1.1698 * *$ & 0.0401 \\
\hline $\operatorname{Ach}_{M i s_{i t \sum(q 1, q 2, q 3)}} * A C A_{i t(q 4)}$ & $3.5503 * *$ & 0.0474 \\
\hline $\operatorname{LogAT} i q 4$ & 0.0245 & 0.1614 \\
\hline$B M_{i q 4}$ & 0.0252 & 0.3997 \\
\hline$L E V_{i q 4}$ & 0.1682 & 0.1455 \\
\hline$R O A_{i q 4}$ & $1.0638 * *$ & 0.0369 \\
\hline Threshold 1 & -0.0765 & 0.2109 \\
\hline Threshold 2 & $-0.2683 * * *$ & $<.0001$ \\
\hline Threshold3 & $-0.1981 * * *$ & 0.0010 \\
\hline Year Fixed Effects & \multicolumn{2}{|c|}{ Yes } \\
\hline Industry Fixed Effects & \multicolumn{2}{|c|}{ Yes } \\
\hline $\mathrm{N}$ & \multicolumn{2}{|c|}{29604} \\
\hline Pseudo- $\mathrm{R}^{2}$ & \multicolumn{2}{|c|}{0.0374} \\
\hline
\end{tabular}

$$
\begin{aligned}
& \left.\sum_{n} \alpha_{12, n} \text { YearDummies }_{n, i t}+\varepsilon_{i t}\right)
\end{aligned}
$$

$* * *, * * *$ denotes significance at $10 \%, 5 \%$ and $1 \%$ level respectively.

Restatement_Period $i t$ is an indicator variable which equals to one if the quarter four of firm $i$ is among the misstatement quarters.

$A c h_{\text {Mis }}{ }_{i t(q 1, q 2, q 3)}$ is a dummy variable equals to one if two criteria are met. 1) Firm $i$ 's current year's performance $\left(R O A_{t}\right)$ is above the peer group, 2) Firm i's cumulative performance $\left(R O A_{\sum(q 1, q 2, q 3)}\right)$ of the first three quarters in year $\mathrm{t}$ is below that of its peer group. $R O A_{\sum(q 1, q 2, q 3)}$ is calculated using income before extraordinary items in quarter 1 , add that in quarter 2 , quarter 3 , then use the cumulative number divided by average of assets at the beginning of quarter 1 and the end of quarter 3 ;

$A C A_{i t(q 4)}$ is abnormal current accruals of the fourth quarter, which is defined as the firm specific residuals from the following equation estimated cross-sectionally for each industry-year-quarter combination.

$\frac{C A_{i t}}{A T_{i t-1}}=\varphi_{0}+\varphi_{1}\left(\frac{1}{A T_{i t-1}}\right)+\varphi_{2}\left(\frac{\Delta R E V_{i t}}{A T_{i t-1}}-\frac{\Delta R E C_{i t}}{A T_{i t-1}}\right)+R O A_{t-1}+\varepsilon_{i t}$

$A c h_{M i s_{i t \sum(q 1, q 2, q 3)}} * A C A_{i t(q 4)}$ is the interaction term of $A c h_{M i s_{i t \sum(q 1, q 2, q 3)}}$ and $A T A_{i t}$.

$\operatorname{LogAT}_{i t(q 4)}$ is natural logarithm of asset at fourth quarter of firm $i$ for year $t ; \mathrm{BM}_{i t(q 4)}$ is book value of equity divided by market value of equity at fourth quarter of year $t$ for firm $i$; $L E V_{i t(q 4)}$ is total liability divided by total assets at fourth quarter of year $t$; $\mathrm{ROA}_{i t(q 4)}$ is income before extraordinary items at fourth quarter of year $t$ in year $t$ divided by the average of total assets of the fourth quarter and beginning of fourth quarter in

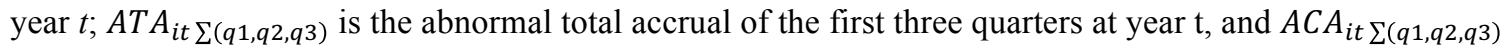
is abnormal working capital accrual of the first three quarters at year $t$. The definitions of abnormal total accrual and abnormal working capital accrual are explained in the previous tables.

Threshold $1_{i t(q 4)}$, Threshold $2_{i t(q 4)}$ or Threshold $3_{i t(q 4)}$ equal one if firm i just meet and beat threshold 1 , threshold 2 or threshold 3 in the fourth quarter of year $t$. respectively.

\section{Table 32}




\section{Financial Statement Restatement of Firms Missing Prior Year's Peer Performance Benchmark}

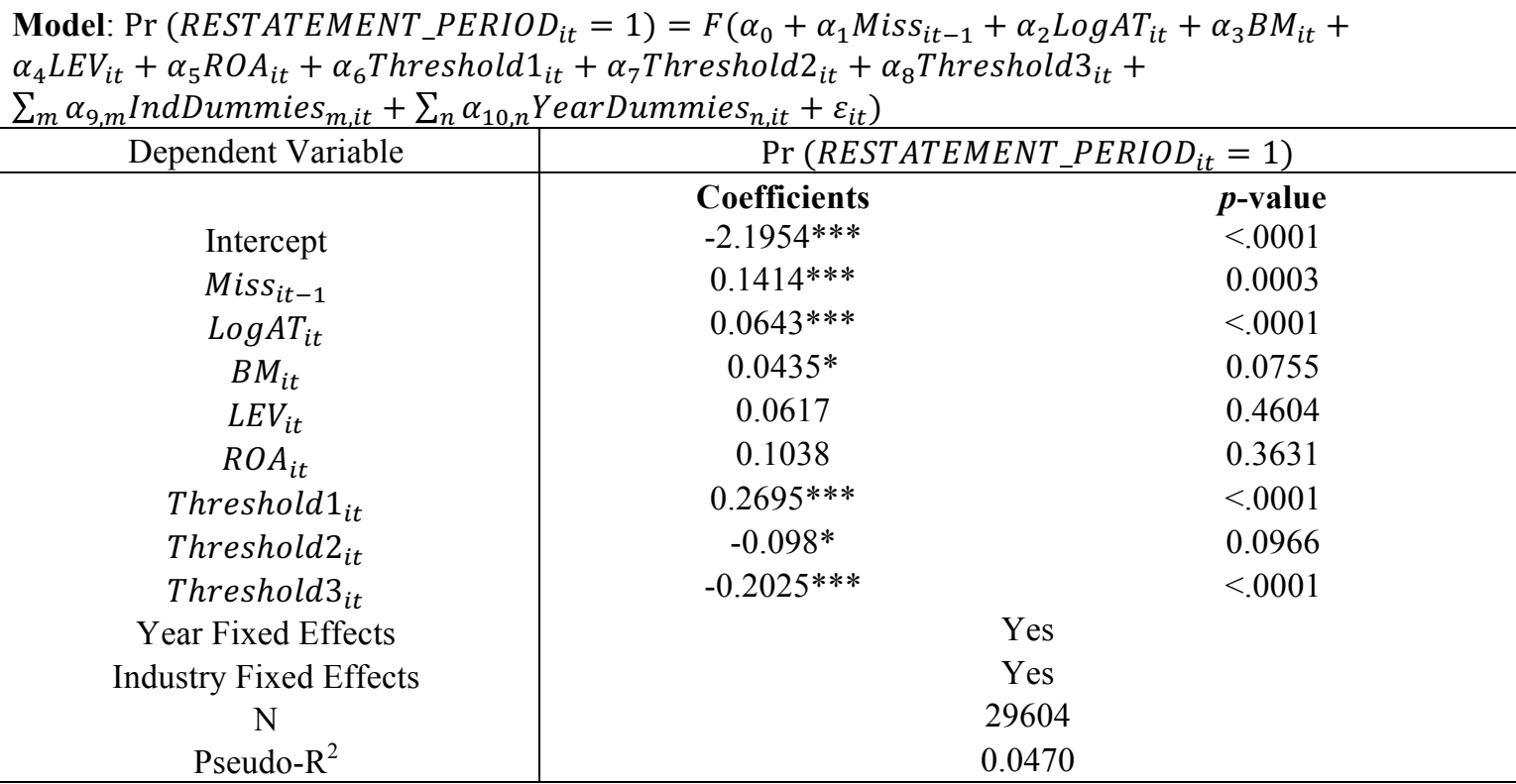

$*, * *, * * *$ denotes significance at $10 \%, 5 \%$ and $1 \%$ level respectively.

Restatement_Period $_{i t}$ is an indicator variable which equals to one if firm $i$ is among the misstatement years.

Miss $_{i t-1}$ is a dummy variable and it equals one if firm $i$ 's prior year's performance $\left(R O A_{t-1}\right)$ is below that of its peer group.

$\operatorname{LogAT} i t$ is the natural logarithm of total assets of firm $i$ for year $t . \mathrm{BM}_{i t}$ is the book value of equity divided by market value of equity in year $t$ for firm $i$. $\mathrm{ROA}_{i t}$ is return on assets defined as income before

extraordinary items in year $t$ divided by the average of total assets. $L E V_{i t}$ is total liability divided by total assets in year $t$.

Threshold $1_{i t}$ is the indicator variable equal to 1 if the firm avoids losses by a small margin, which is defined as income before extraordinary items scaled by the beginning market value within the range of [0.02]. Threshold $2_{i t}$ is the indicator variable equals to 1 if the firm avoids earnings declines by a small margin, which is defined as change in the income before extraordinary items from year $t-1$ to year $\mathrm{t}$, scaled by the beginning market value within the range of [0.01]. Threshold $3_{i t}$ is an indicator variable equal to 1 if the firm avoids negative earnings surprises by a small margin, which is defined as earnings surprises scaled by beginning price per share within the range of [0.0025].

The sample period spans the years 2000 to 2012.

Table 33 


\section{Financial Statement Restatement of Firms Missing Prior Two Year's Mean Peer Performance Benchmark}

\begin{tabular}{|c|c|c|}
\hline Dependent Variable & $\operatorname{Pr}(R E S$ & $t=1)$ \\
\hline Intercept & $\begin{array}{l}\text { Coefficients } \\
-2.2072 * * *\end{array}$ & $\begin{array}{c}p \text {-value } \\
<.0001\end{array}$ \\
\hline $\operatorname{MiSS}_{i \mu(t-1, t-2)}$ & $0.1651 * * *$ & $<.0001$ \\
\hline $\operatorname{LogAT}_{i t}$ & $0.0644 * * *$ & $<.0001$ \\
\hline $\mathrm{BM}_{i t}$ & $0.0449 *$ & 0.0683 \\
\hline$L E V_{i t}$ & 0.0558 & 0.5045 \\
\hline $\mathrm{ROA}_{i t}$ & 0.109 & 0.334 \\
\hline Threshold $1_{i t}$ & $0.2705 * * *$ & $<.0001$ \\
\hline Threshold2 $i t$ & -0.0928 & 0.1158 \\
\hline Threshold $3_{i t}$ & $-0.1998 * * *$ & $<.0001$ \\
\hline Year Fixed Effects & \multicolumn{2}{|c|}{ Yes } \\
\hline Industry Fixed Effects & \multicolumn{2}{|c|}{ Yes } \\
\hline $\mathrm{N}$ & \multicolumn{2}{|c|}{29604} \\
\hline Pseudo- $\mathrm{R}^{2}$ & \multicolumn{2}{|c|}{0.0470} \\
\hline
\end{tabular}

\footnotetext{
$*, * *, * * *$ denotes significance at $10 \%, 5 \%$ and $1 \%$ level respectively.

Restatement_Period ${ }_{i t}$ is an indicator variable which equals to one if firm $i$ is among the misstatement years.

$\operatorname{Miss}_{i \mu(t-1, t-2)}$ is a dummy variable and it equals one if firm $i$ 's average performance $\left(R O A_{\mu(t-1, t-2)}\right)$ of the past two years is below that of its peer group. $R O A_{\mu(t-1, t-2)}$ is calculated using $\frac{R O A_{t-2}+R O A_{t-1}}{2}$.

$\log \mathrm{AT}_{i t}$ is the natural logarithm of total assets of firm $i$ for year $t . \mathrm{BM}_{i t}$ is the book value of equity divided by market value of equity in year $t$ for firm $i$. ROA $i t$ is return on assets defined as income before extraordinary items in year $t$ divided by the average of total assets. $L E V_{i t}$ is total liability divided by total assets in year $t$.

Threshold $1_{i t}$ is the indicator variable equal to 1 if the firm avoids losses by a small margin, which is defined as income before extraordinary items scaled by the beginning market value within the range of [0.02]. Threshold $2_{i t}$ is the indicator variable equals to 1 if the firm avoids earnings declines by a small margin, which is defined as change in the income before extraordinary items from year $t-1$ to year $\mathrm{t}$, scaled by the beginning market value within the range of [0.01]. Threshold $3_{i t}$ is an indicator variable equal to 1 if the firm avoids negative earnings surprises by a small margin, which is defined as earnings surprises scaled by beginning price per share within the range of [0.0025].

The sample period spans the years 2000 to 2012 .
}

Table 34 


\section{Financial Statement Restatement of Firms Missing Current Year's Expected Peer Performance Benchmark}

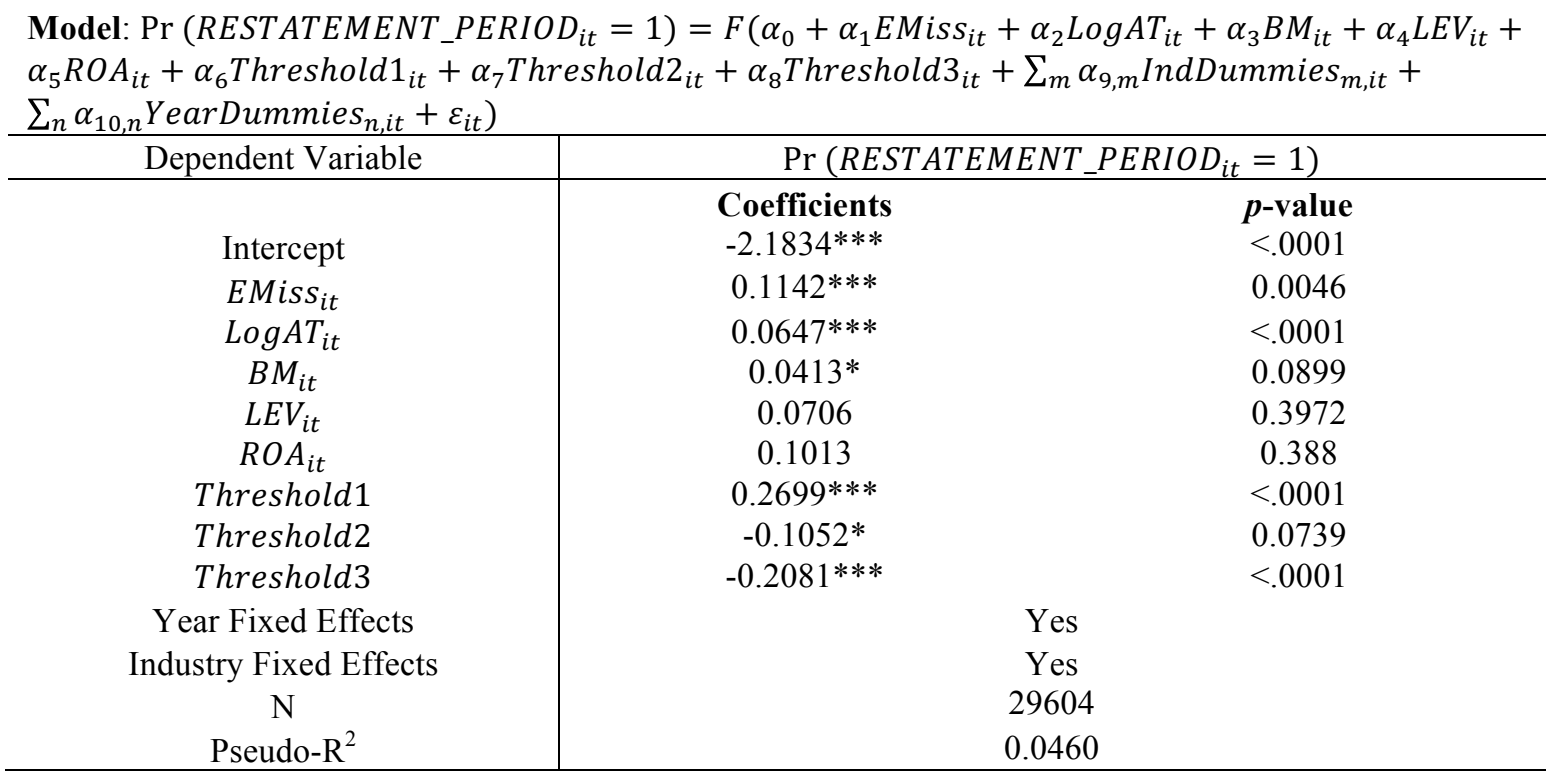

$*, * * * * *$ denotes significance at $10 \%, 5 \%$ and $1 \%$ level respectively.

Restatement_Period ${ }_{i t}$ is an indicator variable which equals to one if firm $i$ is among the misstatement years.

$E$ Miss $_{i t}$ is a dummy variable and it equals one if if firm $i$ 's expected performance Forecasted_EPS $S_{t}$ at year $t$ is below its peer group's expected performance for year $t$. Firm i's expected performance

Forecasted_EPS $S_{t}$ is calculated using analysts' consensus forecasted EPS scaled by scaled by assets per share at the beginning of the fiscal year. Consensus analyst forecasted EPS are the mean analysts' forecasts for the next period.

$\operatorname{LogAT} \mathrm{T}_{i t}$ is the natural logarithm of total assets of firm $i$ for year $t . \mathrm{BM}_{i t}$ is the book value of equity divided by market value of equity in year $t$ for firm $i$. ROA $i t$ is return on assets defined as income before extraordinary items in year $t$ divided by the average of total assets. $L E V_{i t}$ is total liability divided by total assets in year $t$.

Threshold $1_{i t}$ is the indicator variable equal to 1 if the firm avoids losses by a small margin, which is defined as income before extraordinary items scaled by the beginning market value within the range of [0.02]. Threshold $2_{i t}$ is the indicator variable equals to 1 if the firm avoids earnings declines by a small margin, which is defined as change in the income before extraordinary items from year $t$ - 1 to year $\mathrm{t}$, scaled by the beginning market value within the range of [0.01]. Threshold $3_{i t}$ is an indicator variable equal to 1 if the firm avoids negative earnings surprises by a small margin, which is defined as earnings surprises scaled by beginning price per share within the range of [0.0025].

The sample period spans the years 2000 to 2012.

Table 35 


\section{Financial Statement Restatement of Firms Missing First Three Quarters' Cumulative Peer Performance Benchmark}

\begin{tabular}{|c|c|c|}
\hline Dependent Variable & $\operatorname{Pr}(R E S$ & $t=1)$ \\
\hline Intercept & $\begin{array}{l}\text { Coefficients } \\
-2.2419^{* * *}\end{array}$ & $\begin{array}{c}\boldsymbol{p} \text {-value } \\
<.0001\end{array}$ \\
\hline $\operatorname{Miss}_{i}(q 1, q 2, q 3)$ & $0.1888 * * *$ & 0.0014 \\
\hline $\operatorname{LogAT}_{i q 4}$ & 0.0199 & 0.2559 \\
\hline$B M_{i q 4}$ & 0.0174 & 0.551 \\
\hline$L E V_{i q 4}$ & 0.1357 & 0.2417 \\
\hline$R O A_{i q 4}$ & $0.8756^{* *}$ & 0.038 \\
\hline Threshold 1 & -0.0561 & 0.3616 \\
\hline Threshold2 & $-0.2524 * * *$ & 0.0002 \\
\hline Threshold3 & $-0.1826 * * *$ & 0.0024 \\
\hline Year Fixed Effects & & \\
\hline Industry Fixed Effects & & \\
\hline $\mathrm{N}$ & & \\
\hline Pseudo- $\mathrm{R}^{2}$ & & \\
\hline
\end{tabular}

$*, * *, * * *$ denotes significance at $10 \%, 5 \%$ and $1 \%$ level respectively.

Restatement_Period ${ }_{i t}$ is an indicator variable which equals to one if the quarter four of firm $i$ is among the misstatement quarters.

$\operatorname{Miss}_{i t} \sum(q 1, q 2, q 3)$ is a dummy variable which equals one if firm i's cumulative performance $\left(R O A_{\Sigma(q 1, q 2, q 3)}\right)$ of the first three quarters in year $\mathrm{t}$ is below that of its peer group. $R O A_{\sum(q 1, q 2, q 3)}$ is calculated using income before extraordinary items in quarter 1 , add that in quarter 2 , quarter 3 , then use the cumulative number divided by average of assets at the beginning of quarter 1 and the end of quarter 3;

$\operatorname{LogAT}_{i t(q 4)}$ is natural logarithm of asset at fourth quarter of firm $i$ for year $t ; \mathrm{BM}_{i t(q 4)}$ is book value of equity divided by market value of equity at fourth quarter of year $t$ for firm $i$; $L E V_{i t(q 4)}$ is total liability divided by total assets at fourth quarter of year $t$; $\mathrm{ROA}_{i t(q 4)}$ is income before extraordinary items at fourth quarter of year $t$ in year $t$ divided by the average of total assets of the fourth quarter and beginning of fourth quarter in

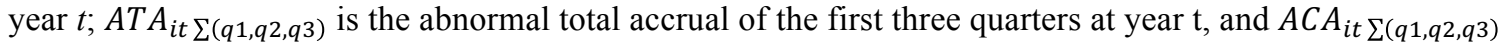
is abnormal working capital accrual of the first three quarters at year $t$. The definitions of abnormal total accrual and abnormal working capital accrual are explained in the previous tables.

Threshold $1_{i t(q 4)}$, Threshold $2_{i t(q 4)}$ or Threshold $3_{i t(q 4)}$ equal one if firm i just meet and beat threshold 1 , threshold 2 or threshold 3 in the fourth quarter of year $t$. respectively. The definition of just meet and beat each threshold is explained in the previous section.

The sample period spans the years 2000 to 2012.

VITA

\section{SHENG YI}




\section{Born, Hunan, China}

2006-2010

B.B.A., Financial Management

Central University of Finance and Economics

Beijing, China

2010-2011

M.S., Accounting

University of Miami

Miami, Florida

2012-2016

Doctoral Candidate in Accounting

Florida International University

Miami, Florida 